Ankara Üniversitesi Türk İnkılâp Tarihi Enstitüsü Atatürk Yolu Dergisi S 40, Kasım 2007, s. 643-691

\title{
Birinci Dünya Savaşı ve Sonrasında Musul Meselesi
}

\author{
Dr. Cemal KEMAL
}

\section{ÖZET}

Mezopotamya (Irak)'nın kuzey bölgesini teşkil eden Musul, Çeşitli kültür ve medeniyetlerin oluşması ve gelişmesinde etkili olmuştur. Musul, Asur'dan itibaren 16 devlet arasında el değiştirmiş, bunların yarısını Türkler oluşturmuş, yaklaşık 800 yıl kadar egemenliğimizde kalmıștır. Osmanlı zamanında Mezopotamya, Musul, Bağdat ve Basra vilayetleri șeklinde yönetilmiștir. Musul, coğrafi, ulaştırma, sosyal, ekonomik, politik askeri özelliklerinden dolayı, tarih boyunca dünyanın büyük devletlerinin çıkar çatışmalarının merkezi haline gelmiştir. Birinci Dünya Savaşı'nda Irak Cephesi'nde savaştı̆̆ımız Ingiliz Ordusu, Ku-tul Amara'da teslim olduktan sonra, yeniden başlattığı taarruzla stratejik hedef olarak seçtiği Musul'u Mondros Mütarekesi şartlarına aykırı olarak, 15 Kasım 1918'de fiilen işgal etmiştir. Musul, Osmanlı Meclis-i Mebusanı tarafından Misak-ı Milli sınırları içinde kabul edilmiştir. Mustafa Kemal, bundan sonra Sevr Antlaşması'nı geçersiz kılmak ve Misak-ı Milli'yi gerçekleştirmek hedefine yönelmiştir. Mustafa Kemal, Birinci Dünya Savaşı, Milli Mücadele, Lozan görüşmeleri ve sonrasında da Musul Meselesi ile çok yakından ilgilenmiş, Ingiltere ile tekrar savașı bile göze almıștır. Türkiye'nin 1922-1926 yılları arasındaki dıs politikasının en önemli parametresini Musul konusu teşkil etmiştir. Türkiye, görüşmelerden olumlu bir sonuç alamaması, İtilaf Devletleri'yle çeşitli problemler yaşaması, iç isyanların ülkenin bütünlügüünü tehdit etmesi ve başlatılan inkılâpların sürdürülmesi nedenlerinden dolayl, 5 Haziran 1926'da Ankara Antlaşması'nı imzalayarak, savaş seçeneğinden vazgeçmiş, Mustafa Kemal' in, "Yurtıa Barış Dünyada Barış" sözlerini dış politikasının parolası haline getirmiş ve Musul'un İngiltere'nin mandası olan Irak'ın sınırlarına dâhil olduğunu kabul etmişıtir. 1890'dan itibaren Ingiltere'nin mandast olan Irak'ın sınırlarına dâhil edilinceye kadar Musul'a bağlı sancak, bugün merkeze bağlı vilayet olarak yönetilen Kerkük, sahip olduğu zengin petrol rezervleriyle, gelecekte de iç ve dış güçlerin çıkar çatışmalarının merkezi olacă̆ı anlaşılmaktadır.

Anahtar Kelimeler: Musul, Irak, Mustafa Kemal, Ismet Paşa, Lord Curzon, Türkiye, Ingiltere, savaş, barıș.

\footnotetext{
• Bilkent Üniversitesi. Öğretim Görevlisi.
} 


\section{The Question of Mosul During and After World War I}

\section{ABSTRACT}

Mosul, which forms the northern region of Mesopotamia (Iraq), has had an effective influence since ancient times in the formation and development of various cultures and civilizations.It has been the site of 16 nations after the Assyrians of which half were Turkish and which remained under Turkish sovereignty for approximately 800 years. During the Ottoman period, Mesopotamia was administered as the provinces of Mosul Baghdad and Basra. Due to its geographic, transport, social, economic, political and military features, Mosul has been the center of conflict of interests among the greater powers throughout history.In the battle against the British army on the Iraqi front during the First World War, after the British surrender at Ku-tul Amara (Kut), Mosul was chosen as a strategic target for a new assault - contrary to the conditions of the Mondros Armistice - and was effectively occupied by the British on 15 November 1918. Mosul was accepted as within the borders of the "Misak-i Milli"(National Pact) by the Ottoman "Meclis- $i$ Mebusan"(Chamber of Deputies). Mustafa Kemal henceforth directed himself to the objective of revoking the Sevr Agreement and realizing Misak-i Mili. Mustafa Kemal gave particular attention to the Question of Mosul during the First World War, the National Struggle and during and after the Lausanne peace conference and was even willing to go to war with Britain again over this question. The most important parameter in Turkish foreign policy between 1922 and 1926 was the subject of Mosul, but because Turkey could not obtain positive results during negotiations and the various problems that occurred with the Allied forces coupled with the threat to the nation's territorial integrity due to domestic rebellions and the continuation of the reforms that had commenced, led to the signing of the Ankara Agreement on 5 June 1926 and the abandonment of the war option. Mustafa Kemal's "Peace at Home, Peace in the World" statement became a benchmark in foreign policy and led to the acceptance of the inclusion of Mosul within the boundaries of Iraq that was a mandated territory of Britain.Until Mosul was annexed within the boundaries of Britain's mandated territory since 1890 of Iraq, the oil rich reserves of Kerkuk, that was a sub province of Mosul and which is today administered as a province, is viewed as a possible center of conflict of interests of both domestic and foreign forces.

Key words: Mosul, Iraq, Mustafa Kemal, Ismet Pasha, Turkey, Britain, War, Peace.

\section{GIRİŞ}

Ortadoğu'nun merkezinde yer alan Mezopotamya'nın kuzey bölgesi olan Musul, M.Ö.800'de Kerkük şehrinin inşasından itibaren, sırasıyla Asur, Babil, Medine (Arap), Emevi, Abbasi, Hemdaniler, Ukayliler, Tuluniler, Büyük Selçuklular, Irak Selçukluları, Zengiler, Erbil Atabeyliği, 
Karakoyunlu, Akkoyunlu, Safaviler ve Osmanlı egemenliğinde kalmıştı.' Kerkük şehri Asurlular tarafından inşa edilmiş, Musul onların dini merkezi olmuştu. ${ }^{2}$ Yavuz Sultan Selim'in Çaldıran Seferi'yle 1516'da Musul, Kanuni Sultan Süleyman'ın 1534'teki Bağdat Seferi'yle de Mezopotamya (Irak) Osmanlı Devleti'nin egemenliği altına girmişti. ${ }^{3}$ Musul vilayeti, doğuda İran, kuzeyde Diyarbekir (Diyarbakır), güneyde Bağdat, batıda Şam, kuzeybatıda Halep vilayetleri ve Zor sancağı ile çevrelenmişti. ${ }^{4}$ Musul, Selçuklu İmparatorluğu'ndan itibaren 800 yıl kadar, Türk devletlerinin sınırları içinde bulunmuştu. Osmanlı'nın Irak toprakları, Musul, Bağdat ve Basra vilayetlerine ayrılmış, 1890 'dan itibaren Musul merkeze bağlı kazalar Kerkük (Şehrizor) ve Süleymaniye sancakları şeklinde yönetilmişti.

Musul, coğrafi mevkisinin Anadolu üzerinden Asya, Avrupa ve Afrika arasında tarihi bir "yol" ve "geçiş güzergâhı" niteliği taşıması, "Mezopotamya"nın dünyanın önemli kültürlerinin geliştiği merkez konumunda bulunması, sahip olduğu yeraltı ve yerüstü kaynaklarının zenginliği ile sürekli olarak büyük güçlerinin çıkar çatışmalarının yaşandığı bölge olmuştur. ${ }^{6}$ Bir Alman heyetinin, 1871'de Musul'da zengin petrol yatakları olduğunu rapor etmesi, bölgeyi büyük devletlerin ilgi alanı haline getirmişti.' Osmanlı'nın Almanya ile anlaşarak, Birinci Dünya Savaşı'na girişi, "Şark Meselesi" için, fırsat yaratmıştı. Şark Meselesi teriminin, ilk defa 1815'te Viyana Kongresi'nde resmi görüşmeler dişında, Rusya temsilcisi tarafından Osmanlı İmparatorluğu idaresinde yaşamakta olan Hıristiyan halkın durumu üzerine dikkat çekmek amacıyla kullanıldığı bilinmektedir. Şark Meselesi; 19.yüzyılın ilk yarısında Osmanlı

${ }^{1}$ Geniş bilgi için bkz. Başbakanlık Devlet Arşivleri Genel Müdürlügüü, Musul-Kerkük ile İlgili Arşiv Belgeleri, 1525-1919, Yayın No: 11, Ankara, 1993, ss. 14 -37.

Başbakanlık Devlet Arşivleri Genel Müdürlügü, Irak Türkleri Bibliyografyası (A Bibliography of Iraqi Türks), Yayın No:12, Ankara, 1994, s.XIII.

Joseph Von Hammer, Osmanlı Tarihi, c. 1, Çev. Mehmet Ata, İstanbul, Milli Eğitim Basımevi, 1997, ss.481-482; Ercan Karh, Osmanl Tarihi, İstanbul, Geçit Kitabevi, 2003, ss. 86-87: Mim Kemal Öke, Musul-Kürdistan Sorunu, 1918-1926, İstanbul, İz Yayıncılık, 1995. s.15; H. Halil Ergene, Neden Hedef Türkiye? Ankara, Kiyap Yayın Dağıtım, 1993. ss.106-107.

${ }^{4}$ Başbakanlık Devlet Arşivleri Genel Müdürlüğü, Musul-Kerkïk ile Illgili Arşiv Belgeleri, 1525-1919,Yayın No:11, s. 3

${ }^{5}$ Başbakanlık Devlet Arşivleri Genel Müdürlüğü, 111 Numaralı Kerkük Livası Mufassal Tahrir Defteri, Yayın No: 64, Ankara, 2003, ss.6-7. Geniş bilgi için bkz. Halil Sahillioğlu,,"Osmanlı Döneminde Irak'ın İdari Taksimant" Çev. Mustafa Öztürk, Türk Tarih Kurumu (TTK) Dergisi, Belleten, (Aralık 1990), c. LIV, Sayı:211, ss. 1233-1257. Musul vilayeti, Birinci Dünya Savaşı'nın hemen öncesinde, 91.000 kilometrekarelik bir toprağa ve yaklaşık 350.000 kişilik bir nüfusa sahip bulunmaktaydı. Bilal N. Şimşir, Türk-Irak Illişilerinde Türkmenler, Ankara, Bilgi Yayınevi, 2004, s.48. Osmanlı İmparatorluğu'nun Musul vilayetinin kapsadığı bölgede halen; Dohuk, Erbil, Süleymaniye, Musul ve Kerkük vilayetleri bulunmaktadır.

Başbakanlık Devlet Arşivleri Genel Müdürlüğü, Irak Türkleri Bibliyografyası (A Bibliography of Iraqi Türks). Yayın No:12, s. XIII.

Öke, Musul-Kürdistan Sorunu, s.41. 
İmparatorluğu'nun toprak bütünlügüüün korunması, aynı asrın ikinci yarısında Türklerin Avrupa'daki topraklarının paylaşılması, 20.yüzyılda da İmparatorluğun bütün topraklarının bölüşülmesi anlamında kullanıldı. ${ }^{8} 11$ Temmuz 1878'de imzalanan Berlin Antlaşması'nın 61.maddesine göre; Ermeniler lehine reformlar yapılmasını Osmanlı Hükümeti'ne kabul ettiren Avrupalılar, böylece Şark Meselesi'ni Osmanlı Devleti'nin Asya'daki topraklarına da intikal ettirmeyi başarmışlardı."

Bu çalışmada, Irak Cephesi'nden başlamak suretiyle 1914-1926 yılları arasında "Birinci Dünya Savaşı ve sonrasında Musul Meselesi" incelenerek, Misak-1 Milli sınırları içersinde yer alan Musul'un İngiltere'nin mandası olan Irak'a bırakılmasının nedenleri tespit edilmeye çalışılacaktır. "Musul Meselesi," Şark Meselesi'nin üçüncü safhasını teşkil eden Birinci Dünya Savaşı'nın Irak Cephesi'nde, Osmanlı İmparatorluğu ve İngiltere arasında yapılan muharebeler ve sonrasında gelişen olaylara göre, belirgin hale gelmiştir.

\section{Birinci Dünya Savaşı'nda Irak Cephesi}

Birinci Dünya Savaşı'nın temel sebebini, Avrupa Büyük Devletleri'nin ekonomik yayılma ve yeni sömürgeler elde etme faaliyetleri sonunda meydana gelen çıkar çatışmaları teşkil etmekle birlikte, başlama kıvılcımını, 28 Haziran 1914'te Avusturya-Macaristan İmparatorluğu'nun Veliahdı Arşidük François Ferdinand'ın Saray Bosna'da bir Sırp milliyetçisi olan Gavrilo Principe tarafından öldürülmesi teşkil etmişti. ${ }^{10}$ Osmanlı Devleti'nin, 1903 'te Berlin-Bağdat Demiryolu'nu yapma ve işletme imtiyazını Almanya'ya vermesi, İngiltere'nin Süveyş Kanalı, Basra Körfezi ve Hindistan ile tüm Uzak Doğu'daki çıkarları için çok ciddi bir tehdit teşkil etmeye başlamıştı. " Bu nedenle, Bazı tarihçiler, Almanya'ya İngiltere'nin Hindistan Yolu (Kral Yolu)'na karadan tehdit etme imkânı sağlayan,

${ }^{8}$ Enver Ziya Karal, Osmanlı Tarihi, c.V, Nizam-l Cedit ve Tanzimat Devirleri, 1789 1856, 2.b., Ankara, Türk Tarih Kurumu (TTK) Yayınları, 1961, ss.204-205. Geniş bilgi için bkz. Ergene, a.g.e., ss.20-31; A. Haluk Cay, Her Yönüyle Kürt Dosyası, 4.b.. Ankara. T. Ofset Matbaacılık, Turan Kültür Vakfı Yayınlanı, 1996, ss.11-25; Hacettepe Üniversitesi, Atatürk ve Türkiye Cumhuriyeti, 5.b., Ankara, Siyasal Kitabevi, 2004, ss. 56-58.

${ }^{9}$ Bayram Kodaman, Sultan II. Abdiühamit Devri Doğu Anadolu Politikası, Ankara, Türk Kültürü Araştırma Enstitüsü Yayınları, 1987, s. 2; Mehmet Saray, Ermenistan ve TürkErmeni Illişkileri, Genişletilmiş 2.b., Ankara, Atatürk Kültür, Dil ve Tarih Kurumu Atatürk Arastırma Merkezi Yayınları, 2005, ss.33-34

"1) Yüksek Öğretim Kurulu (YÖK), Atatürk Illkeleri ve Inkılap Tarihi, Yayın No:6, c.1/1, Türk Inkılabının Hazırlık Dönemi ve Türk İstiklal Savaşı, 3.b., Ankara, Yüksek Ögretim Kurulu (YOK) Yayınları, 1994, s.45.

Enver Ziya Karal, Osmanlt Tarihi, c. IX, İkinci Mesrutiyet ve Birinci Dünya Savaşt, 1908-1918. Ankara, Türk Tarih Kurumu (TTK) Yayınları, 1996, s. 360; Necdet Ekinci. "Imparatorluktan Cumhuriyete, Türk Mali Politikasına Bakıs," Türk Tarih Kurumu Dergisi, Belleten, Aralık 1991, c. LV, Sayr: 214.s. 770. 
1906'da ulaşıma açılan Bağdat Demiryolu'nu, Birinci Dünya Savaşı'nın en önemli sebebi olarak göstermişlerdir. ${ }^{12}$

Avusturya-Macaristan, Sırbistan'a verdiğgi 'ülkesinin bütünlügüüne karşı yürütülen propaganda faaliyetlerinin önlenmesi ve cinayetle ilgisi olanlar hakkında adli soruşturma açılması' konulu notanın yerine getirilmemesi üzerine, 28 Temmuz 1914'te Belgrat'ı bombalayarak savaşı başlatmıştı. Almanya'nın Avusturya-Macaristan, Rusya'nın Sırbistan yanında yer almaları, İngiltere ve Fransa'nın Almanya'ya savaş ilan etmeleriyle askeri harekât Avrupa'ya yayılmıştı. ${ }^{13}$ İtilaf Devletleri (İngiltere, Fransa, Rusya, Sırbistan) ve İttifak Devletleri (Almanya, Avusturya-Macaristan) arasında başlayan, Birinci Dünya Savaşı, Japonya'nın Almanya'ya savaş ilan etmesi, Osmanlı Devleti ve Bulgaristan'ın İttifak Blok'unda, İtalya, Romanya, Amerika Birleşik Devletleri (ABD) ve Yunanistan'ın İtilaf Blok'unda yer almalarıyla 1914-1918 yılları arasında tüm dünyayı etkisi altına almıştı. ${ }^{14}$

Osmanlı Devleti, Birinci Dünya Savaşı öncesi parasını peşin ödemek suretiyle İngiltere'ye "Sultan Reşat" ve "Osmaniye" adlı iki savaş gemisi 1smarlamışt1. İngiltere,"Her Anadolu köylüsünün birer kuruş ödediği bu gemilere" el koymuştu. İngiliz Hükümeti, mürettebatı (askeri personeli) İngiltere'ye gitmiş olmasına rağmen savaş gemilerini vermemişti. ${ }^{15}$ Osmanlı Devleti, teşebbüslerinden olumlu sonuç alamayınca, 2 Ağustos 1914'te Almanya'yla İstanbul'da bir Gizli İttifak Antlaşması imzalamış, aynı gün seferberlik ilan etmişti. ${ }^{16}$ Sadrazam Sait Halim Paşa, Almanya'nın

${ }^{12}$ H.V.F. Wistone'a göre: "Savaştan evvel, Ingiltere'nin Mezopotamya'da alakadar olduğu iki ana mevzuu bulunuyordu: Enver'in casuslartntn faaliyetleri ile Alman Demiryolu (Bağdat Demiryolu) sisteminin ilerleyiși." H.V.F. Wistone, Ortadoğu Serïveni, 1898-1926 Yılları Arasında Ortadoğu'daki Siyasi ve Askeri İstihbaratın Öyküsü, Çev. Fuad Davudoğlu. İstanbul, Risale Yayınları, 1999, s.289; Mim Kemal Öke'ye göre: "Bağdat Demiryolu Projesivle Almanlar, Musul konusuna el atnca, Ingiltere de ezeli dïsman Rusya yla işbirliğine girecektir. Bu gelişmeler. Birinci Dünya Harbi'nde taraf güçleri de belirleyecektir..." Mim Kemal Öke. Musul Meselesi Kronolojisi, 1918-1926, İstanbul, Türk Dünyası Araştırmaları Vakfı Yayınları, 1987, ss. 9-10.

${ }^{3}$ Avusturya-Macaristan'ın, 28 Haziran 1914'te Sırbistan'a verdiği notanın Sırbistan tarafından kabul edilmeyen 6 . maddesi şöyledir: "...28 Haziran'daki cinayetle ilgili olarak, Sirbistan topraklarındaki cinavette parmağı olanlar hakkında adli sorusturma acllacaktır. Avusturya-Macaristan Hükümeti delegeleri bu soruşturma ile ilgili araştırmalara katılacaklardır." Geniş bilgi için bkz. Karal, a.g.e., c. IX, ss.367-373.

${ }^{4}$ Fahir Armaoğlu, 20. Yüzyll Siyasi Tarihi, 2 Cilt, 1914-1995, 12. b, İstanbul, Alkım Yayınevi, 2000, s.100; Coşkun Úçok. Siyasal Tarih. 1789-1950, 5.b., Ankara, Ajans-Türk Matbaası Yayınları, 1961, s.289.

${ }^{15}$ Bilal N. Şimşir, Atatürk ve Cumhuriyet, İstanbul, İleri Yayıncılık, 2006, ss 49-50.

6 Osmanlı İmparatorluğu ile Almanya arasında, 2 Ağustos 1914 'te İstanbul'da imzalanan Gizli İttifak Antlaşması'nın önemli maddeleri şöyledir:

"1. Bugünkü Avusturya- Macaristan ile Strbistan arasindaki anlaşmazhık karşıstnda bu antlaşmayı imzalayan iki devlet, kesin bir tarafsızlık gözetmeyi yüklenirler".

'2. Rusya'nun fiili askeri tedbirlere basvurmast ve bununla Almanva için Avusturya'ya yüklenmeleri bakımından bir düsmanlık durumu varatılması halinde, bu durum Türkiye için de yaratılmıs olacaktır." 
İstanbul'daki Büyükelçisi Wangenheim ile bu gizli antlaşmayı imzaladıktan sonra: "Bu ittifak devletin istiklalini kurtaracaktır" diyerek, gelecekte Osmanlı'yı bekleyen felaketin ön koşullarını da hazırlamış oldu. ${ }^{17}$

Akdeniz'de İngiliz Donanması'nın takibine uğrayan Goeben (Yavuz) ve Breslau (Midilli) adlı iki Alman savaş gemisi, 10 Ağustos 1914'te Çanakkale'ye sığınmıştı. Osmanlı Devleti, tarafsız bir devlet olarak, bu gemilerin silahlarını sökmesi ve personelini de gözaltına alması gerekirken. Almanya ile anlaşarak, bu gemileri önceden satın alındığını ve donanmaya kattığını 11 Ağustos 1914'te ilan etmişti. İtilaf Devletleri, Osmanlı Devleti'nin tarafsızlığını korumak amacıyla, olayı protesto etmişler, fazla tepki göstermemişlerdi. ${ }^{18}$ İstanbul'daki Alman Yardım Heyeti Başkanı General Liman Von Sanders ${ }^{19}$ ve Genelkurmay Karargâhında görevli Yarbay Baron Von Kress Kressenstein, ${ }^{20}$ Osmanlı Devleti'ni Almanya'nın yanında savaşa sokmak için büyük gayret göstermişlerdi. Harbiye Nazın Enver Paşa, Dâhiliye Nazırı Talat, Meclis-i Mebusan Başkanı Halil ve Bahriye Nazırı Ahmet Cemal Paşaları Almanya'nın yanında savaşa katılmaya razı ediyordu. ${ }^{21}$ Yavuz ve Midilli gemilerinin Komutan Amiral Souchon, Enver ve Ahmet Cemal Paşaların emirleriyle, ${ }^{22} 23$ Ekim 1914'te Osmanlı Donanması'nı da alarak, 27 Ekim 1914'te Karadeniz'e çıkmıș, 29 Ekim

“3. Türkiye'nin savaşa girmesi halinde Almanya, Askeri Heyeti'ni Türkive'nin emrinde burakacaktrr. Türkiye de bu heyetin ordunun sevk ve idaresinde kesin bir etkive sahip oimasın. sağlayacaktır..."

"4. Almanya Osmanlt topaklarının tehdit edilmesi halinde ve tehdide uğrayan yerde Osmanl Devleti ne silahla yardım etmevi üzerine alır..." Karal, a.g.e., c. IX, ss.380-381 Şefket Süreyya Aydemir, Tek Adam, c. I, 22. b., Istanbul, Remzi Kitabevi, 2004, ss.190-191; Armaoğlu, a.g.e., s.108

Kemal Arı, Birinci Dünya Savașt Kronolojisi. Ankara, Gnkur. Basımevi, 1997, s. 18

${ }_{18}$ Armaoğlu, a.,g.,e., s.109; Üçok, a.g.e., s.293; Arı, a.g.c., s.28.

19 General Liman Von Sanders, Birinci Dünya Savaşı öncesi Alman Yardım Heyeti Başkanı, savas süresince; Canakkale Cephesi’nde 1.Ordu Komutanı. Filistin Cephesi nde Yıldırım Ordular Grubu Komutanı olarak görev yapmış, Mondros Mütarekesi’nden sonra 31 Ekim 1918'de Yıldırım Ordular Grubu'nu Mustafa Kemal Paşaya teslim ettikten sonra Almanya'ya dönerken Ingilizler tarafından tutuklanarak Malta ya gönderilmiști.

Baron Von Kress, Kressenstein, Birinci Dünya Savaşı'nda, Gnkur. Harekât Başkanı ve Filistin Cephesi'nde 1. ve 2. kanal Harekâtları, 1., 2. ve 3. Gazze Muharebeleri'ne katılmış, 8.Ordu Komutanı olarak görev yapmıs, Gazze nin İngilizlerin eline geçmesinden sonra görevden alınarak Kafkas Cephesi'nde Tiflis'e gönderilmişti.

${ }_{21}$ Talat ve Halil Paşalar, daha sonra fikir değiștirerek, Osmanı’nın tarafsız kalmasını savunmuşlardı. Durumu Almanya'ya bildiren Enver Pașa, Itilaf Devletleri nin kıșkırtılarak. Osmanlı'ya savaş açmalarının sağlanmasına karar vermiştir. David Fromkin, Barışa Son Veren Barıs (A Peace To End All Peace), Modern Orta Doğu Nasıl Yaratıldı? 1914-1922. Cev. Mehmet Harmanc1, Istanbul, Sabah Yayınları, 1994, ss.61-62.

22 Enver Paşanın vermiş olduğu yazılı emir şöyledir: "Türk filoları Karadeniz'de ve zor kullanmak suretiyle hakimivet kazanmalıdır. Rus filosunu aravınız ve nerede bulursanız. savas ilan etmeksizin hücum ediniz." Bahriye Nazırı Ahmet Cemal Pașanın verdiği emir ise şöyledir: "Donanmamızın Birinci Komutanlığına atanmıs olan Amiral Souchon tarafından donanmanın talimi için Karadeniz'de bulunduğu sırada verdiği her çeșit emre harfi harfine uyulmasını ve bu hususta katiyen tereddüt gösterilmeverek emirler gereğinin her türlü haller ve sartlar dairesinde yapılmasım isterim." Karal, a.g.e., c. IX, ss. 393-394. 
1918'de Rus Donanması'na taarruz etmiş, müteakiben Odessa ve Feodosya Novorossik'deki askeri tesisleri bombalamıştı. Osmanlı Devleti, Rusya'ya bir nota vererek, özür diledikten sonra, olaya Rus Filosu'nun sebep olduğunu bildirmiş, Rusya ise cevap notasında bu iddiayı kabul etmemiş, 24 saat içinde Almanların geri gönderilmesini istemiști. Osmanlı'nın Rusya'nın isteğini yerine getirmemesi üzerine, Çar Nikola, bir bildiri ile Osmanlı'ya karşı savaşı başlattığını halkına duyurmuştu. Osmanlı Hükümeti, İngiltere ve Fransa'nın da 4 Kasım 1914'te, kendisine savaş ilanından sonra, bir mazbata düzenleyerek, Padişah'a sunmuş, Ayan ve Mebusan Meclislerinin onayı ile 11 Kasım 1914'te, İtilaf Devletleri'ne savaș ilan etmiștir. ${ }^{23}$ Osmanlı, bu savaşı başlatmamış, üç ay sonra savaşa girmiş olmasına rağmen, Kafkasya, Irak, Çanakkale, İran, Sina-Filistin, Hicaz, Avrupa'da Galiçya, Makedonya ve Romanya olmak üzere 10 cephede mücadele etmek mecburiyetinde kalmıștı. Irak Cephesi'ndeki muharebeler, Osmanlı ile İngiltere arasında cereyan etmiştir. ${ }^{24}$ Irak Cephesi, Bağdat Demiryolu Hattı'nın Halep-MusulBağdat güzergâhını takip etmesi, bu hattın Basra'ya kadar uzatılmasının planlaması, Musul'un stratejik hammadde niteliği taşıyan petrol rezervlerine sahip olması ${ }^{25}$ ve İngiltere'nin Anadolu'nun güneyinden yumuşak karnını tehdit etmesiyle önem kazanmıştır. İngilizler, Osmanlı daha savaşa girmeden önce, bir İngiliz Hint Tümenini, 15 Ekim 1914'te Bahreyn Adaları'na, bu tümenin bir birliğini de savaşın ilanından 10 gün önce 100 Türk askeri tarafından savunulan Basra güneyindeki Fav'a çıkarmışlardı. ${ }^{26}$

İngiliz Ordusu, 23 Kasım 1914'te Basra'yı, 8 Aralık 1914'te Kurna'yı ele geçirmişti. Ingilizler, düşman bir zihniyetle gelmediklerini, Türk yönetimi yerine özgür ve adil bir yönetim kurulacağını, dine ve geleneklere saygı göstereceklerini duyurarak, propaganda yoluyla halkı kazanmaya çalışmışlardır. Enver Paşa, Binbaşı Süleyman Askeri'yi, 3 Ocak 1914'te

${ }^{23}$ Armaoğlu, a.g.e., s.110; YÖK, a.g.e., c.I/I, s.46. Geniş bilgi için bkz. Karal, a.g.e., c.IX, ss. 394-399. Churchill, 31 Ekim 1914 te: "Türkiye'ye karşı hemen harekata başlanması" emrini vermis, İngiliz gemileri, $3 \mathrm{Kasım} 1914$ 'te Canakkale mevzilerini bombalamıs, $4 \mathrm{Kas} ı \mathrm{~m}$ 1914 'te savaş ilan etmiştir. Fromkin, a.g.e., s.63. Osmanlı Imparatorluğu'nun Birinci Dünya Savaşı'na girişinin sorumluluğunu, savaştan sonra Sadrazam Sait Halim, Dahiliye Nazırı Talat, Baskomutan Vekili (Padisah Yardımeısı) Enver, Bahriye Nazırı Ahmet Cemal, Meclis-i Mebusan Başkanı Halil, ve Maliye Nazırı Cavit Paşalar dahil hị̧ kimse üstlenmemiştir. Aydemir, Tek Adam, c.1, ss.194-195.

${ }^{24} \mathrm{Karal}$, a.g.e., c. IX, s.482.

25 Almanya'nın bağımsızlığını kazandığı 1871 'de bir Alman uzmanlar heyeti, Mezopotamya (özellikle Musul)'nın zengin petrol kaynaklarına sahip olduğunu rapor etmiş, bunun üzerine, Padişah II. Abdülhamit 1888 ve 1898 yıllarında yayımladığı iki fermanla, Musul ve Bağdat vilayetlerindeki petrol alanlarının Hazine-i Hassa'ya bağlandığını ilan etmişti. Öke, Musul-Kürdistan Sorunu, s.41.

${ }^{26}$ Ingiltere ve Amerika Birleșik Devletleri (ABD) Koalisyon Kuvvetleri, İkinci Körfez Harekâtı'nda, aynı bölgeye (Fav'a) amfibi müşterek harekât (kara, deniz ve hava kuvvetlerinin işbirliği) icra ederek başarılı olmuşlardır. Bu durum, Ingilizlerin, Birinci Dünya Harbi Irak Cephesi'nde Osmanlı Devleti'ne karșı uyguladıkları hareket tarzına ait harp ceridelerini çok iyi inceleyerek, tarihten ders çıkardıklarının en önemli göstergesidir. 
aşiret ve kabilelerden toplayacağı kuvvetlerin başına atayarak, Basra'yı geri almak için görevlendirmişti. Binbaşı Süleyman Askeri, Ahvaz ve Nasiriye'yi ele geçirmiş, petrol boru hattına sabotajlar yapmış, ancak, Basra'yı tekrar geri almak amaciyla, 12-14 Nisan 1915 tarihleri arasında yaptı $\breve{g}_{1}$ taarruzlarda başarılı olamamıs ve intihar etmiști. ${ }^{27}$ Süleyman Askeri'nin, Basra vilayetini geri almak için yaptığı harekât başarısız olmakla birlikte, İngilizler oldukça telaşlanmışlardı. İran'ın Basra Körfezi'nde bulunan Abadan petrol bölgesini korumak, kuzeye ilerleyerek müttefiki olan Rusya'yla birleşmek ve Türk kuvvetlerinin İran üzerinden Hindistan Yolu'nu kesmesini önlemek amacıyla, General Townshend komutasında harekete geçen İngiliz Kuvvetleri, Türk Kuvvetlerini geri atarak, 3 Haziran 1915'te Amara'ya, 25 Temmuz 1915'te Nasiriye'ye girmişlerdi. İngiliz Ordusu, Eylül 1915'te tekrar harekete geçmiş, 27 Eylül 1914'te Aziziye'yi işgal etmiş, 12 Kasım 1914'te Bağdat'a yürümüş ve 22 Kasım 1915'te Nurettin Paşa komutasındaki Türk Kuvvetleriyle Selmanpak'ta savaşa tutuşmuştu. Selmanpak Muharebesi'nde kuvvetinin üçte birini kaybeden İngilizler, 3 Aralık 1915'te Kut-ul Amara'ya çekilmişlerdi ${ }^{28}$

Osmanlı Devleti, 12 Aralık 1915'te. Irak Cephesi'nde 6.Orduyu kurmuş, komutanlığına Alman Mareşali Von Der Goltz'u atamıştı. Nurettin Paşanın bu atamaya karşı çıkması üzerine görevden alınmış ve yerine Enver Paşanın amcası Halil Paşa atanmıştı. İngilizler, 7 Aralık 1915'ten 29 Nisan 1916'ya kadar dört ay 23 gün Kut-ul Amara'da kuşatılmış durumda kalmışlardı. ${ }^{29}$ General Townshend komutasındaki İngiliz Ordusu, kuşatılmış bulunan kuvvetlerini kurtarmak için, 21 Ocak, 7 Mart, 7 Nisan, 24 Nisan 1916 tarihlerinde dört defa Çemberi Yarma teşebbüsünde bulunmuşsa da başarılı olamamıştı. İngiliz Ordusu, T.E.Lawrence'in ${ }^{30}$ de bulunduğu bir heyetin, Von der Goltz Paşanın veba hastalığından ölümünden sonra yerine atanan Enver Paşanın amcası Halil Paşa ile görüşmesinden sonra 29 Nisan 1916'da, yaklaşık 13.100 (13.309) kişilik ordusuyla Türk Kuvvetlerine teslim olmuştu. ${ }^{31}$

\footnotetext{
${ }^{27}$ Karal, a.g.c., c. IX, s.486.

${ }^{28}$ Armaoğlu, a.g.e., s.112.

29) Gnkur.ATASE Bşk.lığı, Birinci Dünva Harbi'nde Türk Harbi,, c. III, Ks.2, Irak-Iran Cephesi, 1914-1918, Ankara, Gnkur. Basımevi, 2002, s.4

30 T.E.Lawrence, 10 Nisan 1916'da Misır'dan Mezopotamya'ya gitmis, 29 Nisan 1916'da Townshend komutasındaki İngiliz Ordusunun teslim belgesini onaylamıs, Mayıs 1916 sonlarında Kahire'ye dönmüştür. Savaş Bakanı Lord Kitchener'in verdiği yetkiyle İngilizlerin Ortadoğu politikasını yürüten Lawrence, 5 Haziran 1916'da Arap İsyanı'nın başlamasını sağlamıs, Filistin Cephesi'nin cöküsünün ön kosullarını hazırlayan bu isyan, birleşik kaplar esasına göre Irak Cephesi'ni de çok olumsuz şekilde etkilemiştir. Daniel Yergin Petrol. Para ve Güç Catışasının Epik Öyküsü, çev. Kamuran Tuncay, 2.b., Ankara, Türkiye İș Bankası Kültür Yayınları, 1999, s.230; Fromkin, a.g.e., s.194; Geniş bilgi için bkz. Winstone, a.g.e., ss. 282-325

${ }^{31}$ Ingiliz Irak Cephesi Komutanı General Townshend, erzak yetiştirme operasyonunun fayda vermediğini görünce, 25 Nisan 1916 'da, 6.Ordu Komutanlığına teslim şartlarını müzakere etmeyi teklif etmiş, 26 Nisan 1916'da başlayan müzakereler, 29 Nisan 1916'da, 5
} 
Enver Paşa, Kut-ul Amara'da kazanılan başarıyı güney istikametinde geliştirerek, Basra'yı ele geçirmeyi ve İngilizleri Irak'tan tamamen atmayı planlamamıştı. Enver Paşanın Almanların isteklerine uyarak, İran'ı Rus Kuvvetlerinden temizlemek üzere, 13.Kolorduyu İran'a göndermesi, Irak Cephesi'ni zayıflatmıștı. Bu durumu fırsat olarak değerlendiren İngilizler. Irak Cephesi'ndeki kuvvetlerini takviye ederek, 13 Aralık 1916'da tekrar kuzey istikametinde ilerlemeye başlamışlardır. Bu sırada,'İngiliz Ordusu'na karşı savaşmak üzere, Irak Cephesi'nde bulunan 6.Ordunun 13.Kolordusu İran'da, 7.Kolordusu Musul'da, 18.Kolordusu Bağdat güneyinde bulunmaktaydı. Bu durumu da firsat olarak değerlendiren İngilizler, 12 Ocak 1917 'de genel taarruza geçmişlerdi. Halil Pașa, İngiliz Kuvvetlerine imha olmamak için, 25 Şubat 1916'da Kut-el Amara'yı bırakarak, Bağdat istikametinde geri çekilmiş, Bağdat'ın güneyinde yeni bir savunma tesis etmek için, İran'daki 13.Kolorduyu geri çağırmış, ancak geç kalmıştır. Türk Kuvvetleri, Aziziye ve Selmanpak'ta düşmanı durdurmaya çalışmış, fakat başarılı olamamıştı. Türk Ordusunun Bağdat'ı boşaltarak geri çekilmesini fark eden İngilizler, 11 Mart 1917 'de şehri ele geçirmişlerdi. ${ }^{32}$ Mustafa Kemal Paşa, Bağdat'ın işgalinden iki gün sonra 13 Mart 1917'de, 16.Kolordu Komutanlığından merkezi Diyarbakır'da bulunan 2.Ordu Komutanlığına atanmıştı. ${ }^{3.3}$

Başkomutan Vekili Enver Paşa, 24 Haziran 1917'de Kafkas Ordular Grup Komutanı Ahmet İzzet Paşa, 2.Ordu Komutanı Mustafa Kemal Paşa, 4.Ordu Komutanı Ahmet Cemal Paşa, 6.Ordu Komutanı Halil Paşa, Osmanlı Genelkurmay Başkanı Bronzart Paşanın katılımlarıyla Bağdat'ın geri alınmasını görüşmek üzere, Halep'te bir toplantı düzenlemişti. ${ }^{34}$ Mustafa Kemal Paşa, 5 Temmuz 1917'de Enver Paşanın telgrafına cevaben Yıldırım Ordular Grubunun 7.Ordu Komutanlığını kabul ettiğini bildirmişti. ${ }^{35}$

general, 481 subay olmak üzere toplam 13.100 personelin kayıtsız şartsız teslim olmalarıyla sonuçlanmıştır. Başbakanlık Devlet Arşivleri Genel Müdürlügü, Musul-Kerkük ile İlgili Arşiı Belgeleri, 1525-1919, Yayın No.11, s.33; Karal, a.g.e., c. IX, ss.487-488, Arı, a.g.e., ss.217218. Jean-Paul Roux, Türklerin Tarihi, Büyük Okyanus'tan Akdeniz'e İki Bin Yıl, Çev. Galip Üstün, 6.b., İstanbul, Milliyet Yayınları, 1998, s.232. İngiliz Kuvvetleri, Bağdat'a hareketleriyle teslim olmaları arasında geçen süre içinde 10.000 , Kut'tan kurtarılmaları için yapılan harekatlarda 23.000 olmak üzere toplam 33.000 kişi zayiat vermişlerdir. Fromkin, a.g.e., s.195. Gnkur. ATASE Bşk.lığı kayıtlarında, Townshend'in Ordusunun 5 general, 476 subay, 12.828 er olmak üzere toplam 13.309 personelle teslim olduğu belirtilmistir. Gnkur. ATASE Bşk.lı̆̆ı, Birinci Dünya Harbi'nde Türk Harbi, Irak-Iran Cephesi, 1914-1918, c. III. Ks. 2, s. 4 .

${ }_{32}$ Basbakanlık Devlet Arşivleri Genel Müdürlüğü, Musul-Kerkük ile İlgili Arşiv Belgeleri, 1525-1919, Yayın No: 11, s.33; Wistone, a.g.e., s.374; Üçok, a.g.e., s.297; Karal, a.g.e., c.IX, s. 512; Arı, a.g.e., s.267; Simşir, Türk-Irak Illiskilerinde Türkmenler, s.49; Gnkur. ATASE Bşk.lığı, Birinci Dünya Harbi'nde Türk Harbi, c. III, Ks.2, Iran-Irak Cephesi, s. 317.

${ }^{33}$ Ari, a.g.e., s. 267.

${ }^{34}$ Gnkur. ATASE Bşk.lığı, Birinci Dünya Harbi'nde Türk Harbi, c. IV, Ks. 2, SinaFilistin Cephesi, Ankara, Gnkur. Basımevi, 1986, s. 69.

${ }^{35}$ Şükrü Tezer, Atatürk'ün Hatıra Defteri, 3.b., Ankara, TTK Yayınları,1995, s.130. 
Bağdat'ı geri almak amacıyla, 11 Temmuz 1917'de Padişah'ın onayının alınmasını müteakip, Birinci Dünya Savaşı'nın başlangıcında Almanya'nın Genelkurmay Başkanı olan Mareşal Falkenhayn komutasında Yıldırım Ordular Grubu kurulmuştu. ${ }^{36}$ İngilizlerin Sina-Filistin Cephesi'nde Üçüncü Gazze Taarruzu'nu yapacaklarının anlaşılması ve durumun kritikleşmesi üzerine, Bağdat harekâtından vazgeçilmiş, Yıldırım Ordular Grubu SinaFilistin Cephesi'ne tahsis edilmişti. ${ }^{37}$ Yıldırım Ordular Grubunda 7.Ordu Komutanı olan Mustafa Kemal Paşa, bu orduda 3.Kolordu Komutanı Albay İsmet Beyle (İnönü) birlikte hazırladığı 20 Eylül 1917 tarihli, ülkenin koşullarını, Alman Mareşali Falkenhayn ile çalışamayacağını bildiren tarihi raporunu, Başkomutan Vekili Enver, Dahiliye Nazırı Talat ve Bahriye Nazırı Ahmet Cemal Paşalara göndermiş, Enver Paşa tarafından ciddiye alınmadığını görünce, 9 Ekim 1917'de istifa etmiş, Fevzi Paşanın (Çakmak) komuta ettiği, eski görevi olan 2.Ordu Komutanlığını da kabul etmemiş, bir ay izinli sayılarak Istanbul'a gitmiş, yerine Fevzi Paşa görevlendirilmişti. ${ }^{38}$ Mustafa Kemal Paşa, 7.Ordu Komutanlığından ayrıldıktan sonra, Halep'ten İstanbul'a gidebilmek için, tren bileti alacak parasının olmadığını şöyle ifade etmiştir:

“...Burada hatırıma gelen hazin bir noktayı da ilgilenirseniz işaret edeyim. Ben, Halep'te mevki ve görevime son veren bu girişimde bulunduğum ve en son teklif olunan 2.Ordu Komutanlığınt da reddettiğim sirada, Halep'ten Ístanbul'a gitmek için, tren ücreti ödeyecek kadar param olmadı̆̆ını bilmiyormuşum... Yalnız, beş-on atım ve kısrağım vardı. Zamanla edinilmiş ve yetiştirilmiş cins atlar ve kısraklardt. Salih'i çă̆ırdım ve: Bu atlardan bir kaçını satıp da İstanbul'a gidebilirim dedim... Fakat benim en güzel atlarımı pazarda satın alacak bir tek adam çıkmamıştır... Cemal Paşa,

${ }^{36}$ Gnkur. ATASE Bşk.lığı, Birinci Dünya Harbi 'nde Türk Harbi, c.IV, Ks.2, SinaFilistin Cephesi, s. 83; Tezer, a.g.e., s.129.

${ }^{7}$ Arı, a.g.e., ss.283-284. Mustafa Kemal Paşa, Padişah VI. Mehmet Vahdettin'in emriyle 5 Ağustos 1918'de tekrar 7.Ordu, 31 Ekim 1918'de Yıldırım Ordular Grubu Komutanı olarak atanmıștır. Gnkur. ATASE Bşk.lı̆̆ı, Birinci Dünya Harbi 'nde Türk Harbi, c.III, Ks.2, Irak-Iran Cephesi, s.471.

38. Mustafa Kemal, 20 Eylül 1917 tarihli raporunda Irak Cephesi ile ilgili şunları ifade etmiştir:

...Irak'ta Ingilizler hedeflerini ele geçirmişlerdir. Bu sebeple istilalarım daha ileri götürmeleri için siyasi, iktisadi ve askeri zorunlulukta olmadıkları kanısindayım. Bununla heraber, onlar harekâtın sürdürür ve basartya ulașırlarsa, kaybedilenlere, örne ğin Musul'un da ilavesi, kesin sonuca pek etki yapmaz. Denilebilir ki, genel durum adeta değişmemis olur. O halde bu cephede dahi beklemekten başka bir şey yapamayız... Sözzïn kısası, gerek mülki idare ve gerekse halk içinde yapılacak islerin herhangi bir olağan memleket sorunu değil, en birinci bir memleket savunması olduğu, bu dönemde yurdun hiçbir köşesinin herhangi bir yabanct idaresi altına verilmesi, saltanat hayatın kesin olarak yıkar ve ortadan kaldırır..." Mustafa Kemal bu sözleriyle adeta savaşı sonucuna ve Musul'un geleceğine işaret etmiștir. Gnkur. ATASE Bşk.lığı, Birinci Dünya Harbi'nde Türk Harbi, c. IV, Ks. 2, Sina-Filistin Cephesi, ss.106-111; Aydemir, Tek Adam, c.I, ss.273-274; Arı, a.g.e., ss. 292-293; Geniş bilgi için bkz. Tezer, a.g.e., ss.141-160. Mareşal Falkenhayn'ın yerine, 25 Şubat 1918'de, bir başka Ảlman Mareşal Liman Von Sanders atanmıștı. Karal, a.g.e., c. IX, s. 534. 
hepsi için iki bin altın teklif etti, kabul ettim ve bu suretle İstanbul'a hareket ettik... Bir gün İstanbul'da Bahriye Müsteşarı Vasıf Paşadan bir tezkere aldım. Bu tezkereye bağlı 'Cemal Paşa' imzall telgrafta şunlar yazıyordu: Hayvanlarınızı beş bin liraya sattım Sizden çok ucuz almıșım. Üç bin lirasını nereye göndereyim?.. Cemal Paşa merhum, üç bin lirayı Vasıf Paşa aracıllı̆̆ ile bana göndermişti..." ${ }^{39}$

\section{Osmanl İmparatorluğu'nun Paylaşılmast}

Orta Doğu devletleri ve haritası, İtilaf Devletleri'nin Birinci Dünya Savaşı devam ederken verdikleri kararlara dayanmaktadır..$^{40}$ İtilaf Devletleri (Ingiltere, Fransa, Rusya ve İtalya), hasta adam olarak ifade ettikleri ve savaş sonrası kesin olarak dağılacağına inandıkları Osmanlı İmparatorluğu'nun topraklarını paylaşmak için, Birinci Dünya Savaşı süresince aralarında gizli antlaşmalar yapmışlardır. Orta Doğu devletlerinin bugünkü coğrafi sınırları bilindiği gibi, itilaf Devletleri’nin, Birinci Dünya Savaşı esnasında aralarında yaptıkları bu gizli antlaşmalarla belirlenmiştir. Osmanlı Devleti'nin Birinci Dünya Savaşı'nda İttifak Devletleri (Almanya ve Avusturya-Macaristan)'nin yanında yer alması, önceden düşünülen paylaşma planının uygulanmasını hem kolaylaştırmış hem de süratlendirmiştir. ${ }^{41}$

Rusya, İngiltere ve Fransa'nın, 25 Şubat 1915'te Çanakkale Boğazı girişindeki tabyaları bombalamaları üzerine, 4 Mart 1915'te anılan devletlerin elçilerine bir nota vererek, savaşın sonunda; İstanbul ve Boğazlar'la Midye-Enez hattının doğusu, Sakarya ağzı-Gemlik Körfezi batısı arasında kalan bölgeyle Çanakkale Boğazı çıkışında bulunan Gökçeada ve Bozcaada'y1 istiyordu. Rusya buna karşılık, müttefiki olan İngiltere ve Fransa'nın Anadolu ve Orta Doğu'daki Osmanlı topraklarıyla İskenderun Körfezi ve Toroslar'a kadar Çukurova bölgesi üzerindeki haklarını tanıyordu. ${ }^{42}$

İngiltere. Fransa ve İtalya, Çanakkale Savaşları'nın kara harekatı başlarken, 25-26 Nisan 1915'te, Londra'da bir gizli antlaşma imzalamışlardı. Bu antlaşmaya göre; İtalya'nın 1911 yılında yapılan Trablusgarp Savaşı esnasında ele geçirdiği Trablusgarp, Bingazi ve 12 Ada'yı tamamen egemenliği altına alması, İngiltere, Fransa ve Rusya, Türkiye'nin Asya'daki

${ }^{34}$ Falih Rıfkı Atay ve Mahmut Soydan, Atatürk'ün Anıları, 1917-1919, Ankara, Olgaç Matbaası, 1982, ss.25-36; Y1lmaz Çetiner, Son Padisah Vahdettin, 2.b., İstanbul, Milliyet Yayınları,1993, ss.47-48; Aydemir, Tek Adam, c. I, ss.275-276; Vamik D. Volkan ve Norman Itzkowitz, Ölümsüz Atatürk, Ankara, Bağlam Yayınları, 1998, s.144. Mustafa Kemal Paşa, 7. Ordu Komutanlığı görevini, vekaleten Ali Rıza Paşaya bırakarak, 11 Ekim 1917'de İstanbul'a gelmiştir.

${ }_{4}^{4)}$ Fromkin, a.g.e., s.1

${ }^{41}$ Turan, a.g.e., s. 67

${ }^{42}$ Selahattin Tansel, Mondros'tan Mudanya'ya Kadar, c. I, İstanbul, Milli Eğitim Bakanlığı Yayınlan, 1991, ss.157-158; Karal, a.g.e., c. IX, ss. 541-542. 
topraklarını paylaştıkları takdirde, İtalya'ya Antalya bölgesinde onlara eşit pay verilmesi kabul ediliyordu. ${ }^{43}$

İngiliz Ordusu Irak Cephesi'nde Kut-ul Amara'da kuşatılmışken, İngiltere adına Mark Sykes, Fransa adına General Picot tarafından 26 Nisan9 Mayis 1916 tarihlerinde teati edilen belgelerle Sykes-Picot gizli Antlaşması imzalanmıștı. Bu antlaşmaya göre: Boğazlar ile doğuda Trabzon'un batısında belirlenecek bir noktaya kadar olan bölgenin, Van ve Bitlis'in güneyine doğru Muş, Siirt, Fırat, Cezire-i Ömer ve Ameriye'ye kadar uzanan yerler Rusya'ya veriliyordu. Aladağ, Kayseri, AkdağYıldızdağ, Zara, Eğin, Harput'la sinırlanan araziyle Kilikya, Suriye ve "Musul” Fransa'ya, Hayfa, Akka, Irak ve Fransa'ya verilen bölgenin güneyi İngiltere'ye, Filistin uluslar arası idareye tahsis ediliyordu. ${ }^{44}$

Birinci Dünya Savaşı devam ederken, Rusya'da, 12 Mart 1917'de Çarlık devrilmiş ve Bolşevik rejimi kurulmuştur. ${ }^{45}$ Rusya'nın ihtilalden sonra savaştan çekilmesi üzerine, İngiltere ve Fransa İtalya'yı kendi yanlarında savaşa sokmak için, yeni tavizler vermeye razı olmuşlardı. İtalya, İngiltere ve Fransa temsilcilerinin, 21 Nisan 1917'de St. Jean de Maurienne'de aldıkları kararlar göre: Sykes-Picot Antlaşması'nı kabul etmek şartıyla, Antalya'ya ilaveten İzmir de İtalya'ya veriliyor, Konya'ya kadar bir nüfuz bölgesi tanınıyordu. ${ }^{46} \mathrm{Bu}$ antlaşmanın geçerli olması için, Rusya tarafından da kabul edilmesi gerekiyordu. Rusya, Bolşevik İhtilali nedeniyle savaştan çekilmiş ve bu kararları imzalamamıştı. İtilaf Devletleri, Osmanlı İmparatorluğu'nu paylaşmak amacıyla yaptıkları bu antlaşmalarla, 'Şark Meselesi' adını verdileri sorun da görünürde köklü bir biçimde çözülmüş oluyordu. ${ }^{47}$

\section{Mondros Mütarekesi'ne Giden Yol}

Mondros Mütarekesi'nden önce 4 Temmuz 1918'de, Osmanlı Padişahı Sultan V.Mehmet Reşat ölmüş ve yerine Veliaht VI. Mehmet Vahdettin Padişah olmuştu. ${ }^{48}$ Türk Ordusunun Altınköprü'ye çekilmesini fırsat olarak değerlendiren İngiltere, Sykes-Picot Antlaşması'nda Fransa'ya vermeyi

${ }^{43}$ Karal, a.g.e., c. IX, ss.542-544; Turan, a.g.e., ss.67-68; Ayferi Göze, Türk Kurtuluş Savaşı ve Devrim Tarihi, 4. b., İstanbul, Beta Basım Yayım ve Dağıtım, 1993, ss.3-4.

${ }^{44}$ Göze, a.g.e., s.4; Wistone, a.g.e., s.313; Turan, a.g.e., s.68, Karal, a.g.e., c. IX, s..544; Armaoğlu, a.g.e., s. 125, 321. Birinci Dünya Savaşı esnasında, İtilaf Devletleri arasında yapılan Sykes-Picot Antlaşması'nda, ilk defa "Musul” konusu açık olarak gündeme getirilmiş, bu bölge Fransa'ya tahsis edilmiști. Bu Antlaşma imzalandığı sırada, İngiliz Kuvvetlerinin Bağdat ve Musul'u ele geçirmek amacıyla icra ettiği harekât başarısızlıkla sonuçlanmış ve Ingiliz Ordusu 29 Nisan 1916'da Kut-ul Amara'da Türk Ordusuna teslim olmuştu. Hacettepe Üniversitesi, Atatürk ve Türkiye Cumhuriyeti, 5.b., Ankara, Siyasal Kitabevi, 2004, s.107.

${ }^{45}$ Armaoğlu, a.g.e., s.131.

${ }^{46}$ Tansel, a.g.e., s.160; Turan, a.g.e., s.69; Arı,a.g.e., s.275; Göze, a.g.e., ss.4-5; Karal, a.g.e, c. IX, ss. 545-566; Armaoğlu, a.g.e., ss.135-136

${ }^{47}$ Karal, a.g.e., c. IX, s. 546

${ }^{48}$ Ar1, a.g.e., s. 360 , 
taahhüt ettiği Kerkük'ü, 7 Mayıs 1918'de işgal etmiş, 25 Mayıs 1918'de geri alınan Kerkük, 25 Ekim 1918'de tekrar İngilizlerin eline geçmişti. ${ }^{49}$ Osmanlı İmparatorluğu, Birinci Dünya Harbi'nde İtilaf Devletleri'ne karşı savaştığı 10 cepheden sadece Irak ve Filistin Cepheleri'nde mağlup olarak toprak kaybına uğramıştır. Sadrazam Ahmet İzzet Paşa Hükümeti, Bulgaristan'ın 29 Eylül 1918'de mütarekeyi kabul ederek, Birinci Dünya Savaşı'ndan çekilmesinden sonra, Anadolu'nun işgale uğramaması ve halkın daha fazla ezilmemesi için, bir an önce mütareke yapmayı düşünüyordu.$^{50}$ Osmanlı Devleti'nin, mütareke yapmaya karar vermesinde, Hükümet Programı'nda belirtildiği şekilde, ABD Başkanı Wilson'ın 14 maddelik bildirisinin 12.maddesi de etkili olmuştur. ${ }^{51}$ Mondros Mütarekesi imzalandığında, Ali İhsan Paşanın komutasındaki 6.Ordu, Musul'un 120 kilometre güneyinde Ane-Küçükzap-Altınköprü-Kerkük-Süleymaniye hattında bulunmaktaydı. Filistin Cephesinde bulunan Mustafa Kemal Paşanın komutasındaki 7. Ordunun Halep kuzeyine çekilme harekâtına paralel olarak 6. Ordunun da daha kuzeye çekilmesi ve iki ordunun müşterek bir cephe tesis etmesi düşünülmekteydi. ${ }^{52}$

Sadrazam Ahmet İzzet Paşa, Irak Cephesi'nde Kut-ul Amara'da esir alınan ve halen İstanbul Heybeliada'da tutuklu bulunan General Townshend'la görüşmüştür. O da 18 Ekim 1918'de Akdeniz'deki İngiliz Filosu Komutanı Amiral Calthorpe'un yanına gitmiş, Osmanlı Devleti'nin

${ }^{49}$ Başbakanlık Devlet Arşivleri Genel Müdürlüğü, Musul-Kerkük ile Ilgili Arşiv Belgeleri, 1525-1919, Yayın No: 11, s. 33; Başbakanlık Devlet Arşivleri Genel Müdürlüğü, 111 Numaralı Kerkük Livast Mufassal Tahrir Defteri, Yayın No: 46, s.3; Gnkur. AT ASE B̧̧k.lığı, Birinci Dünya Harbi'nde Türk Harbi, c.III, Ks.2, Irak-Iran Cephesi s. 540, 543. 573; Arı, a.g.e., s.350, 353-354, 391. İngilizlerin Kerkük üi işgal ettiği 25 Ekim $1918^{\prime}$ 'de Mustafa Kemal'in 7.Ordusu, İngiliz ve Arap Ordularını Halep kuzeyinde mağlup ederek durdurmayı başarmış ve Anadolu'ya girmelerine müsaade etmemiştir. Aydemir, Tek Adam. c.1, s.288; Gnkur. ATASE Bşk.lığı, Birinci Dünya Harbi'nde Türk Harbi, c. IV, Ks.2, SinaFilistin Cephesi, ss .728-729.

s) Sadrazam Ahmet Izzet Paşa 19 Ekim 1918'de Meclis-i Mebusanda okuduğu Hükümet Programında:

"I. İçte ve dışta barışın sağlanması gereklidir..."

"3. Wilson Prensiplerine uygun bir bartşı kabul edeceğiz."

"4. Arap illeri işini, Halifelik ve Saltanat'a bağhlıkları baki kalmak şarttyla bir muhtariyet vermek suretiyle çözü̈mlemeye çalışacă̆ız." demiştir. Gnkur. ATAŞE Bşk.lığı. Birinci Dünya Harbi'nde Türk Harbi, c.IV, Ks.2, Sina-Filistin Cephesi, ss.106-111; Turan, a.g.e., s. 72

${ }_{51}$ Tarihe "Wilson Prensipleri " olarak geçen bu bildirinin 12. maddesinde: “...Osmanlt Imparatorluğu'nun Türk olan kısımlarının egemenliği să̆lanacak, fakat Türk olmavan milliyetlere muhtar gelişme imkânları verilecek. Canakkale Boğazı devamlı olarak bütün milletlerin gemilerine açı olacak ve bu, milletlerarası garanti altına konacak..." denilmekteydi. Gnkur. ATASE Bşk.lığı, Türk İstiklal Harbi, c.1, Mondros Mütarekesi ve Tatbikatı, 3.b, Ankara, Gnkur. Basımevi, 1999, s.31, Turan, a.,g.,e., s.72; Üçok, a.g.e., s.313; Armaoğlu, a.g.e., s.139; Sabahattin Selek, Anadolu Ihtilali, c. I, 4.b., Istanbul, Burçak Yayınevi, 4. b., 1968, s.35; Hacettepe Üniversitesi, a.g.e., s.111.

s.15. ${ }^{52}$ Gnkur. ATASE Bşk.lığı, Türk İstiklal Harbi, c. I, Mondros Mütarekesi ve Tatbikatı, 
mütareke isteğini iletmiş, 23 Ekim 1918 'de Ahmet İzzet Paşaya bir telgraf çekerek, mütareke şartlarını görüşmek üzere, Osmanlı temsilcilerinin gönderilmesini talep etmiștir. ${ }^{53}$ Osmanlı Mütareke Heyeti'ne; Bahriye Nazırı Rauf (Orbay), Hariciye Müsteşarı Reşat Hikmet, Kurmay Yarbay Sadullah Bey, Heyet Kâtipliğine Ali Bey görevlendirilmişlerdi. Heyet, 24 Ekim 1918'de İstanbul'dan hareket ederek, 26 Ekim 1918'de Limni Adası'ndaki Mondros Limanı'na ulaşmış, 27 Ekim 1918 'de Amiral Calthorpe başkanlığındaki İngiliz Heyeti'yle görüşmeye başlamıştır. Mondros Mütarekesi, 31 Ekim 1918 günü öğleden sonra yürürlüğe girmek üzere 30 Ekim 1918 günü saat 20.03 'te imzalanmıştı. ${ }^{54}$

Ordinaryüs Prof. Dr. Enver Ziya Karal'a göre: "Mondros Mütarekesi'nin karakteri; Osmanll Imparatorluğu'na son vermesi, imparatorluk dışında kalan Türkiye'nin paylaşılmasına zemin hazırlaması ve Osmanlı Imparatorluğu'nun egemenliğini kısıtlanması noktalarında toplanabilir." ${ }^{55}$ Mustafa Kemal Paşa, Mondros Mütarekesi'nin imzalanmasından bir gün sonra Yıldırım Ordular Grubu Komutanlığına atanmıştı. ${ }^{56}$ Mustafa Kemal Paşa, 31 Ekim 1918'de Yıldırım Ordular Grubu Komutanlığını Mareşal Liman Von Sanders'ten teslim aldıktan sonra (Karargahı Adana'da, cephesi Halep kuzeyinde) birliklerini takviye ederek ve yeniden tertipleyerek, Anadolu'nun güneyinden yumuşak karnına

${ }^{53}$ Osmanlı Hükümeti'nin İspanya aracılığıyla barıs isteği, ABD Başkanı Wilson tarafından 31 Ekim $1918^{\circ}$ e kadar cevaplandırılmamıştır. ABD, bu sırada Osmanlı Devleti'ne savaş ilan etmeyi düşünmüş, ancak 30 Ekim 1918'de Mondros Mütarekesi imzalandığından geç kalmıştır. Theodor Roosevelt, 24 Ekim 1918'de:“ Bir saat dahi kaybetmeksizin Türkiye 'ye savaş açılmalıdır." demiştir. Karal, a.g.e., c. IX, ss.557-558.

${ }^{34}$ Mondros Mütarekesi'nin Irak Cephesi'ni ilgilendiren maddeleri şunlardır:

"5. Hudutların muhafazası ve ic asayişin devam ettirilmesi için lüzum görülecek askeri kuvvetten maadasının (başkasının) derhal terhisini, iş bu Kuva-yı Askeriye (askeri kuvvet)'nin mikıar ve vazivetleri Itilaf Hükümetleri tarafindan Devlet-i Aliveyle müzakere edildikten sonra, takarrur ettirilecektir (karar verilecektir).

"7. Müttefikler, emniyetlerini tehdit edecek vaziyet zuhurunda(durumunda) herhangi stratejik noktasint isgal etme hakkına haiz olacaklardır."

“'16. Hicaz'da, Asir'de, Yemen'de, Suriye'de ve Irak'ta bulunan muhafiz kataat en yakın Itilaf komutanına teslim olunacaktır. Ve Kilikya'daki Kuvvetlerin intizamı muhafaza için gerekli miktardan maadası (baskast) 5. maddedeki sartlara tevikan (uvarınca) kararlaşıtırlacak vechile (şekilde) geri çekilecektir.” Gnkur. ATASE Bşk.lığı Arşivi, Istiklal Harbi Koleksiyonu: ISH., Kutu (K):7, Gömlek (G):82, Belge No(B):82-1; a.g.a, K.7, G.83, B.83-1; a.g.a., K.7, G.83, B.83-6. Arı, a.g.e., ss. 393-394. Ingilizler, 25 Ekim 1918'de başlattıkları taarruzla Mondros Mütarekesi’nin imza edildiği 30 Ekim 1918 günü Kalatürşarük'te bulunan 6.Ordunun Diçle Grubunu esir almışlardır. Fahri Belen, Birinci Cihan Harbi'nde Türk Harbi, c.V, 1918 Yll Hareketleri, Ankara, Gnkur. Basımevi, 1983. s.221; Selek, Anadolu Íhtilali, c.I, ss.41-43. Bu duruma göre, sekiz piyade alayı, 8192 personel, 3546 hayvan ve 57 top düşmana terk edilmiştir. Gnkur.ATASE Bşk.lığı, Birinci Dünva Harbi'nde Türk Harbi, Iran-Irak Cephesi, 1914-1918, c. III, Ks.2, ss .588-589.: Gnkur. ATASE Bşk.lığı, Birinci Dünya Harbi'nde Türk Harbi, c. IV, Ks.2, Sina-Filistin Cephesi, ss.734-735.

${ }_{45}^{55}$ Karal, a.g.e., c. IX, ss.560-561.

${ }^{\text {*h }}$ Tezer, a.g.e., s.174. 
yönelmiş bulunan İngiliz Ordusunun tehdidine karşı, Irak cephesi ile koordineli olarak Filistin Cephesi'nde mücadeleyi sürdürmek istiyordu... ${ }^{57}$

Irak Cephesi'ndeki 6.Ordu Komutanı Ali İhsan Paşanın 1 Kasım 1918 sabahı İngiliz Irak Cephesi Komutanı General Marshall'a gönderdiği mektubunda, Mondros Mütarekesi'nin imzalandığ 30 Ekim 1918'de iki taraf kuvvetlerinin bulundukları hatlar arasındaki arazinin tarafsız bölge olduğu özellikle belirtilmişti. 6.Ordu karşısındaki İngiliz Ordusu mütareke imzalandığı anda, Ane-El Hazar-Gayya-regaz kuyuları-Altınköprü-KerkükTuzhurmata-Selahiye-Hanikin hattında bulunmaktaydı. ${ }^{58}$ General Marshall, Ali İhsan Paşanın gönderdiği mektuba karşıllk olarak 2 Kasım 1918'de verdiği cevabında: "Mondros Mütarekesi'nin 7.maddesine göre, lüzum gördü̈̈̈̈ stratejik noktaların işgal hakkına haiz olduğunu, 16. maddeye göre de, Irak'ta bulunan Türk birliklerinin teslim olmalarl gerektiğini" bildirmiști. ${ }^{59}$ General Marshall'ın mektubundan; Musul vilayetini (Musul. Erbil, Süleymaniye ve Kerkük) ve Güneydoğu Anadolu'nun stratejik noktalarını işgal ederek petrol bölgesini kontrol etmek ve Sykes-Picot Antlaşması'nın şartlarını gerçekleştirmek istediği anlaşılmaktaydı.

İngiliz Süvari Tümeni Komutanı General Cassel'e Musul'u işgal etmesi ve Irak hududu içinde bulunan bütün garnizonların silah, mühimmat, erzak ve teçhizatına el koyması emredilmişti. İngilizler, gerekli tebligatı yaptıktan sonra, Musul şehrini kuşatmak üzere 3 Kasım 1918 'de hareket etmişlerdi. General Cassel; "Irak'ın kuzey hududunun Süleymaniye-Köysancak-ErbilAkra-Amadiye-Siirt-Silvan-Ergani-Osmanive-Siverek hattından geçtiğini, bu hattın güneyinde kalan tüm Türk birliklerinin silah ve cephaneleriyle birlikte

\footnotetext{
${ }^{57}$ Mustafa Kemal, sorumluluk bölgesinin savunulması hakkındaki düşüncelerini hatıra defterinde söyle açıklamıștır:

"Yıldırım Ordular Grubu Komutanlığın ïzerime aldıktan sonra düşündüğüm esasl noktalar suniardl: Doğrudan doğruya elim altında bulunan kuvvetleri gecirdikleri bütün badirelere rağmen, ise yarar gerçek kuvvet haline getirmek, tensik etmek, teskil etmek, takvive etmek. Hicaz Kuvveyi Seferiyesi'ni, Maan kuvvetlerini hiçte hesaba katmayı düşünmedim. Onların aslında tutsak olmaya mahkûm oldukların iki yıl önce Cemal ve Enver Pasalara anlatmıstım. Musul yöresinde bulunan 6.Orduyu, faydalanılacak bir durumda görmek isterdim. Bu maksatla,bu ordunun komutanıla doğrudan doğruya muhabereye giriștim. Istanbul ve Canakkale yöresinde bulunan kuvvetlere umut bağiamıvordum. Doğuda Azerbaycan ve Iran'da bulunan ordularla hiçbir ilişkim ve temasım yoktu. Onlar için henüz bir şey düşünecek halde değildim. Aden kapısını zorlayan Sait Paşa Tümeninin mevcudiyetini bile hatırlamıyorum. Fakat her seyden önce elimin aitunda bulunan 7 ve 2 . Orduların istediğim biçimde takviyesi halinde, bütün felaketlere rağmen. Türk sesinin işittirilebileceğ kanısındaydım. Bu yolda ise başladım, bana yardım eden ordu, kolordu komutanları ve kurmay arkadaslartm benim bu düsünce ve görüslerimi anlamıs ve bana her ihtimale karst yardım etmeye söz vermiş kişilerdi." Falih Rıfkı Atay, Mustafa Kemal'in Mütareke Defteri. İstanbul, Sel Yayınları, 1955,ss.6-12; Gnkur. ATASE Bşk.lı̆̆ı, Birinci Dünya Harbi 'nde Türk Harbi, c. IV, Ks.2, Sina-Filistin Cephesi, ss. 732-733; Belen, a.g.e., c.V., s.216. s. 110 .

${ }^{58}$ Gnkur. ATASE Bşk.lığı, Türk Ístiklal Harbi, c. I, Mondros Mütarekesi ve Tatbikat,

${ }^{59}$ Gnkur. ATAŞE Bşk.lığı, Birinci Dünya Harbi nde Türk Harbi, c. III, Ks.2, Irak-Iran Cephesi. s. 614
} 
teslim edilmesini" istemişti. ${ }^{60} \mathrm{Bu}$ istek, Musul ve Diyarbakır vilayetleriyle Urfa ve Siirt sancaklarının da Irak sınırlarına dâhil edilmesi anlamını taşımaktaydı. İngiliz birlikleri, Mondros Mütarekesi şartlarına aykırı olarak ve mütareke imzalandığı anda bulunulan hattı ihlal ederek, 3 Kasım 1918'de Musul'a girmişlerdir. ${ }^{61}$

Osmanl, Mondros Mütarekesi şartlarına göre, bir taraftan işgal edilir ve parçalanırken, bir taraftan da iktidar mücadelesi içinde bulunmaktaydı. Ahmet İzzet Paşa, 14 Ekim 1918'de, Enver ve Talat Paşaların yerine Sadrazam ve Erkan-1 Harbiye-i umumiye Reisi (Genelkurmay Başkanı) olduktan sonra, Talat, Enver, ve Ahmet Cemal Paşalar, İngiliz Ordusu Musul'a girdiği gün 2-3 Kasım 1918 gecesi yurt dışına kaçmışlardı ${ }^{62}$ Filistin Cephesi'nde Yıldırım Orduları Grubu Komutanı Mustafa Kemal Paşa, Mondros Mütarekesi şartlarında açık olarak belirtilmediği halde, İtilaf Devletleri temsilcilerinin istekleri, Osmanlı Hükümeti'nin de bu istekleri kabul etme eğilimi karşısında. 6 Kasım 1918'de Sadrazam Ahmet İzzet Paşaya düşüncelerini şöyle yazmıştı:

“...I Iskenderun'a her ne sebep ve bahane ile asker çıkarmaya teşebbüs edecek Ingilizlere ateşle karşı konmasını ve 7.Orduya hâlihazır bulunulan hatta gayet zaylf bir ileri karakol tertibatl bırakarak, büyük kısmı KatmaIslâhiye istikametine hareketle Kilikya hududuna girmesini emrettim. Ingilizlerin kandırıcı muamele, teklif ve hareketlerini Ingilizlerden ziyade mühik ve nazik gösterecek ve buna mukabil cemile ibrazımı mutazammın olacak (kapsayacak) emirleri tatbik etmeye yaradılışım elvermediğinden, halbuki Başkomutanlık Genelkurmay Başkanlığının düşünceleri doğrultusunda hareket edemediği takdirde birçok töhmet altında kalaca ğım tabii olduğundan, komutayı hemen teslim etmek üzere, yerime tayin edeceğiniz zata ivedi tebliğini hassaten istirham eylerim." ${ }^{63}$ s. 115 .

${ }^{\otimes 0}$ Gnkur. ATASE Bşk. lı̆̆ı, Türk Istiklal Harbi, c. I, Mondros Mütarekesi ve Tatbikatı.

${ }^{61}$ Gnkur. Ataşe Bşk .lığı, Birinci Dünya Harbi'nde Türk Harbi, c. III, Ks.2, Irak-İran Cephesi, s. 618; Armaoğlu; a.g.e., s.142; Turan, a.g.e., ss. 73-74. "Rauf Bey ve heyeti, Istanbul' a dönünce ateskes antlasmasının bir teslim antlasması olmadığını ileri sürerek. koşullarım olduğundan daha yumuşak göstermeye çalıştılar." Fromkin, a.g.e.,s.371. Ancak, İngiliz Ordusu, 3 Kasım 1918'de Musul'a, 9 Kasim 1918'de İskenderun'a ve Itilaf Devletleri Donanması 13 Kasım 1918'de İstanbul'a girince aldatıldıklarını ve yanıldıklarını anlamıslardı.

6̊̃ Başbakanlık Devlet Arşivleri Genel Müdürlüğü, Musul-Kerkük ile Illgili Arşiv Belgeleri, Yayın No.11, s.33; Atatürk, Nutuk 7.b., Ankara, Türk Dil Kurumu (TDK) Yayınları, Gnkur. Basımevi, 1981, s.1; Winstone, a.g.e.,s.75; Şefket Süreyya Aydemir, Makedonya'dan Ortaasya'ya Enver Paşa, c. III, 1914-1922, İstanbul, Remzi Kitabevi, 1993, ss.493-494; Bernard Lewis, Modern Türkive'nin Doğuşu, Çev. Metin Kıratlı, 9.b., Ankara, Türk Tarih Kurumu (TTK) Yayınları, 2004, ss. 239-240.

Gnkur. ATASE Bşk.lı̆̆ı Arsivi, K.67, G.70, B.70-2; Atatürk'ün Tamim, Telgraf ve Beyannameleri (ATTB), c. IV. Ankara. Türk Inkılap Tarihi Enstitüsü Yayınları, Türk Tarih Kurumu (TTK) Basımevi, 1991, ss.19-20. 
Amiral Calthorpe'un yanında bulunan Osmanlı Devleti'nin irtibat subayı Deniz Yüzbaşısı Şefket imzasıyla Mustafa Kemal Paşaya gelen telgrafta: "Britanya Hükümeti'nden aldi ğım talimata tevfikan Mütareke'nin 7, 10 ve 16. maddeleri gere ğince, İskenderun Komutanı'nın, General Allenby tarafindan kendisine bildirilecek müddet zarfinda, sehri teslim etmesini, aksi takdirde mezkur (adl geçen) generalin sehri zorla işgal edeceğini zatınıza teklif ve komutana talimat verilmesini talep ederim" yazıyordu ${ }^{64}$ İngilizler, Mustafa Kemal'in düşüncelerini ve endişelerini teyit eden, İskenderun'un teslimi hakkındaki isteklerini nihayet bildirmişlerdi. İngilizler ve Fransızlar, Rauf Bey (Orbay)'in imzaladı $\breve{g}_{1}$ Mondros Mütarekesi şartlarını ve ülkemizin işgal edilmeyeceği teminatını ihlal etmeye başlamışlardı ${ }^{65}$ Ahmet İzzet Paşa, önceki mesajlarını tekzip eder mahiyette 8 Kasım 1918'de, Mustafa Kemal Paşaya : "Şehri teslim teklifine hak ve salahiyetleri yoksa da, İskenderun şehri için Mütareke feshedilemeyeceğinden, müracaat halinde sehrin tahliye ve teslim edilmesini" emrediyordu. ${ }^{66}$ Mustafa Kemal Paşa, İskenderun'un boşaltılmasına dair Ahmet İzzet Paşadan aldığ emri, 8 Kasım 1918'de ilgililere tebliğ etmiş, İskenderun'un İtilâf Devletleri'ne verilmesinin mahzurlarını da şöyle açıklamıştı:

“...6.Ordu Komutanı'nın, 7 Kasım 1918 tarihli rapor muhteviyatına nazaran Ingilizleri Nusaybin-Cerablus-Halep demiryolunu işgale isaret olan ve Irak Ingiliz Ordusu Başkomutani'nın Musul'un derhal terk edilmesini ve aksi takdirde zorla gireceği hakkında teklifi ne suretle açıklanabilir? Ingilizlerle yapllan Mütareke'nin imzalanan şekli, Osmanlı Hükümeti'nin selametini içerecek mahiyette değildir. Mezkur maddelerin şüpheli ve müspet manalarının bir an evvel tespit edilmesi lazımdır. Yoksa Ingilizlerin isteklerine bugüne kadar olduğu gibi mukabelede devam olunduğu takdirde, Payas-Kilis hattına kadar olan araziyi isteyen Ingilizlerin yarın Toros'a kadar olan Kilikya mıntıkasını ve daha sonra Konya-İzmir hattının işgalinin lüzumlu olduğu tekliflerinin birbirlerini takip edeceği ve sonuçta Ordumuzun kendileri tarafindan sevk ve idaresi, hatta Bakanlar Kurulunun Britanya Hükümeti tarafindan seçilmesi lüzumu gibi tekliflerin karşısında kalınmak durumunda bulunulacaktır. Şahsen, her ne hal ve durumda bulunursam

${ }^{64}$ Gnkur. ATASE Bşk.lı̆̆ı Arşivi, K.67, G.75, B.75-2

${ }^{65}$ Rauf Bey (Orbay) anılarında, Ingilizler'in Mondros'ta kendisini aldattıklarını ve verdikleri sözlerinde durmadıklarını söyle anlatmaktadır: "Kırım Savaslari'ndan beri Ingilizlerin ve Fransızların yalnız ahitlerine değil, vaatlerine de sadık milletler oldukları hakkında milletimizde umumi bir kanaat vardt. Bu kanaate ben de istirak edivordum. Ne yazlk ki, bu fikir ve kanaatlerimizde yanılmıstık. Mütareke'nin hemen ertesi günleri, gördüğümüz hareket tarzlarıyla tamamıyla hayal kurıklı̆̆ına uğradık! . Rızalartyla kabul ettikleri sartlara. hiçbir makul sebep olmaksizın riayet etmediler ve Mütarekename'yi yırta yirta parçaladılar!.." Çetiner, a.g.e., ss. 30-31.

${ }^{66}$ Ginkur. ATASE Bșk. lığı Arșivi, K.7, G.21, B.21-2; K.67, G.72, B.72-1. 
bulunayım, doğruluğuna kani olduğum bu hususu icap edenlere arz etmeyi memleketin selameti bakımindan uygun bulurum..." 67

Mustafa Kemal, Sadrazam Ahmet İzzet Paşayı ikna edemeyince, verilen emre uyarak İskenderun'u İngilizlere teslim etmek zorunda kalmıştı. ${ }^{68}$ İskenderun'un teslimiyle ilgili protokol"İskenderun'un civarı, 9 Kasım 1918 'den itibaren Osmanlı Ordusu tarafindan tamamen boşaltılacaktır...10 Kasım 1918 saat 08.00'de Amanos Dağları ve İskenderun Körfezi'yle çevrili bölgeyle Payas'a kadar olan arazi Osmanlı Ordusu tarafindan boşaltılacak, bu saatten sonra yakalanacaklar harp esiri sayllacaklar ve düsmanca davrananlar kurșuna dizilecektir. Tahliye edilen yerlerdeki orduya ait malzeme yerinde birakılacak ve sonra haklarında muamele yapılacaktır..." şeklindeydi. ${ }^{69}$ Mustafa Kemal, İngilizlerle yapılan Protokol hakkında Genelkurmay Başkanlığına: "i skenderun, 9 Kasım 1918'de, 15 kișilik bir Ingiliz kıtası tarafindan işgal edilmiștir. Ingilizler yalnız şehri işgal etmekle kalmamışlar, aynı zamanda şehri Anadolu'dan tecrit etmişlerdir. 41.Tümen Payas ve kuzeyine alınmış, Antakya'da bırakılan bir bölük de, Reyhanll üzerinden 24.Tümene kattlmıştır" yazılı bir rapor gönderiyordu. $^{70}$

İngilizler, Sadrazam Ahmet İzzet Paşayı kullanarak İskenderun'u ele geçirmeyi başarmışlardır. Ahmet İzzet Paşa, Mustafa Kemal'in, İngilizlerle Fransızlara karşı mücadeleye devam etme azim ve kararlılığı karşısında, Mondros Mütarekesi şartlarını ihlal edeceğinden korkarak, 7 Kasım 1918'de, Yıldırım Ordular Grubu'nu ve 7.Orduyu lağvetmiştir. Mustafa Kemal, 31 Ekim 1918'te teslim aldığı Yıldırım Ordular Grubunu bir hafta süreyle sevk ve idare etmiş, İngilizlere teslim etmemiş, özellikle bu gücün subay kadrosu Milli Mücadele'de Düzenli Orduya geçişin ön koşullarını hazırlamıştır. ${ }^{71}$ İngilizler, 9 Kasım 1918'de İskenderun'u ele geçirdikten sonra, 11 Kasım 1918 'de Musul'u işgal etmişlerdir. ${ }^{72}$ Mustafa Kemal Paşa, Yarbay Halit Beyin 22 Ocak 1922'de Batı Cephesi Komutanlığına gönderdiği bir rapora dayanarak, Musul vilayetinin Ali İhsan Paşanın ihmali sonucu

67 a.g.a., K.5.G.27,B.27-1; a.g.a., K.67,G.73,B.73-1; Atatürk'ün Tamim, Telgraf ve Beyannameleri, ss.21-22.

${ }_{68}$ Ingilizler, Mondros Mütarekesi Şartlarına aykırı olarak Filistin Cephesi nde İskenderun sancağı ve Irak Cephesi'nde Musul vilayeti için aynı taktiği, eș zamanlı olarak uygulamışlardır. a.g.a., K.1,G.6, B.6-1;6-7;6-9.

${ }_{69}$ a.g.a., K.5, G. 29, B. $29-1$.

${ }^{70}$ a.g.a., K. 5. G. 27, B. $27-1$.

${ }^{71}$ Volkan, a.g.e., s.155; Çetiner, a.g.e.,s.28; Tansel, a.g.e., c. I, s.47; Turan, a.g.e., s.101; Aydemir, Tek Adam, c. I, s.317. Yıldırım Ordular Grubunu teşkil eden: 3.Kolordu Samsun ve Sivas'a, 15.Kolordu Erzurum'a, 20.Kolordu Ankara'ya, 12.Kolordu Konya'ya intikal ettirilmiş, Mustafa Kemal, Milli Mücadele'ye başlarken, bu güzergahı takip etmiş, isyanların bastırılması, Doğu ve Batı Cephesi'ndeki Muharebeler büyük ölçüde bu kuvvetler tarafından icra edilmiştir.

${ }^{72}$ Hacettepe Üniversitesi, a.g.e., s.273. 
kaybedildiğini değerlendirmiştir. ${ }^{73}$ Selahattin Tansel'e göre:'SÖzzün kısast, Ingilizler, birkaç gün önce imzaladıkları bir mütarekeye saygı göstermediği ve Osmanlı Hükümeti de gereğinden fazla korkak davrandlø̆̆ için, Musul terk edildi." ${ }^{74}$ Türk birlikleri, İngilizlerle yapılan toplantıda alınan karar gereğince, 15 Kasım 1918 öyleye kadar Musul'u İngilizlere tamamen terk ettiler. İngilizler, Türk memurlarını görevlerinden alarak Musul vilayeti dışına çıkardılar, Musul vilayetine bağlı Revandüz, Akra, Zaho, Telafer ve Sincar kazalarının da 30 Kasım 1918 günü öyleye kadar boşaltılmasını istediler. ${ }^{75}$

\section{Sevr Antlaşması'na Giden Yol}

İtilaf Devletleri, Avrupa'nın sorunlarını çözmek, Almanya, AvusturyaMacaristan ve Bulgaristan ile yapılacak barış antlaşmalarının şartlarını tespit etmek amacıyla, Paris'te bir konferans toplamayı kararlaştırmışlardı. Paris Barış Konferansı, 32 devletin temsilcilerinin katılımıyla 18 Ocak 1919'da Fransa'da toplanmıștı. ABD, Wilson Prensipleri'nde belirtildiği şekilde milliyet esasına göre, sınırların belirlenmesini savunduğundan, Milletler Cemiyeti'nin statüsü tespit edildikten sonra, görüşmelerden çekilmişti. Konferans'ta, İngiltere ve Fransa'nın istekleriyle manda ${ }^{76}$ rejiminin

${ }^{73}$ Mustafa Kemal'in Nutuk' ta belirttiği Yarbay Halit Beyin raporu söyledir: "Ateskes Antlaşmast'ndan bir gün önce 13.000 kişinin tutsak verilmesi, 50'ye yakın topun elden çıması, gerçekte kendisinin, duruma uygun olmayan bir buyruk vermesinden doğmuştur. Iște bu durum. Musul ilinin elden çıkmasına yoi açtı. Oysa Ateşkes Antlaşması'nın yapılacağı biliniyordu. Gruba Keyare dayangasına (savunma hattına) çekilmek için yönerge verilseydi. Ingilizler, Grubu tutsak etmek söyle dursun, yenemezlerdi bile. Dicle Grubuna 5.Tümen de katılabilirdi. Böylece Ateșkes Antlașmast yapıldı ğı zaman, tutsak edilen sekiz piyade alayı elde bulunur ve Musul da bizde kaltrdl." Atatürk, Nutuk, ss.488-489. Dicle Grup Komutanı Yarbay İsmail Hakkı Bey, savunmasında: "Dicle Grubunum bu elim duruma düsmesinden Ordu Komutanı Ali Ihsan Paşayı sorumlu tutmuştur. Grup Komutamı: '70 kilometrelik cepheyi tek tek gözden geçiremediğini ve özellikle harekat başladığı sirada, gerekli yerlerde bulunina olanağının kalmadı ğını' belirtmekte, bunun için de 'grubun elinde mevcut tek otomobilin Ordu Komutanı emriyle Ordu Karargahına gönderilmis olduğunu' sebep göstermekte, '...Kendisine itimadı olmayan Ordu Komutanı, niç̧in 200 kilometre uzaktaki Musul'dan harekant idare ediyor?..." demektedir. Gnkur. ATAŞE Bşk.lığı, Birinci Dünya Harbi inde Türk Harbi, c.III, Ks.2. Irak-iran Cephesi, ss. 595-596.

${ }^{74}$ Tansel, a.g.e., c. I, s. 42.

${ }^{75}$ Gnkur. ATASE Bsk.lığı, Birinci Dünya Harbi'nde Türk Harbi, c.III, Ks. 2, Irak-Iran Cephesi, s.619. Şimşir, Türk-Irak İlişkilerinde Türkmenler, s.49. Ali İhsan Paşa, Irak Cephesi'nden İstanbul'a gelirken 2 Mart 1919'da Haydarpaşa Tren İstasyonu'nda tutuklanarak Malta'ya götürülmüştür. Hacettepe Üniversitesi, a.g.e., s.117.

${ }^{76}$ Manda:"Birinci Dünya Savaşı 'ndan sonra kimi azgelişmiş ülkeleri, kendi kendilerini yönetecek bir düzeye eriștirip, bağımsızlığa kavuşturuncaya dek Uluslar Birliği (Milletler Cemiyeti, Cemiyeti Akvam) adına yönetmek için kimi büyük devletlere verilen vekillik." Manda, Fransizca Mandat kelimesinden gelir ve vazife, emirname demektir. Uluslar Birliği'nin kurulması, Wilson Prensipleri'nin 14. maddesinde ifade edilmiști. Manda sisteminin esaslarının belirlenmesi, 28 Nisan 1919'da, Paris Barıs Konferansı'nda, anayasası kabul edilen Milletler Cemiyeti'nin takdirine bırakılmıştı. 28 Haziran 1919'da Almanya ile imzalanan Versailles Barıs Antlaşması'na göre: Almanya'nın sömürgelerinde Milletler Cemiyeti'nin kontrolü altında manda rejimi kurulması kabul edilmişti. Armaoğlu, a.g.e., ss.140-141. Manda Sistemi hakkında daha fazla bilgi için, bkz. Üçok, a.g.e., ss.329-331. 
kurulması ve St. Jean de Maurienne Antlaşması'nda İtalya'ya verilen İzmir'in Yunanistan'a tahsis edilmesi kabul edilmiş ve barış antlaşmaları taslakları hazırlanmıştı. ${ }^{77}$ Paris Barış Konferansı devam ederken, Yunan Ordusu 15 Mayıs 1919'da İzmir'e, 16 Mayıs 1919'da İstanbul'dan Bandırma Vapuru'yla hareket eden Mustafa Kemal Paşa 19 Mayıs 1919'da Samsun'a çıkmıştı ${ }^{78}$ Sadrazam Damat Ferit Paşa Elazığ Valisi Ali Galip'i, İngiltere Binbaşı Noel'i, Anadolu'da başlayan kongreler ve teşkilatlanmaları engellemek amacıyla görevlendirmișlerdi. ${ }^{79}$ Binbaşı Noel'e göre: "I $\sum_{s ̧} s t k l$ tutulduğu takdirde, himayeleri alıında, kuzey sınırı Van Gölü'ne kadar uzanacak bir Kürt devleti kurulması zor olmayacaktır" $"$ Mustafa Kemal, Erzurum Kongresi'nden, Sivas Kongresi'ne giderken, ${ }^{81}$ Noel'in Kürtler arasında milliyetçilik fikirleri uyandırarak, isyana teşvik ettiği haberini almıştı. Noel, İngiliz Casusu Lawrence'in Filistin Cephesi'nde yaptıklarını, Güneydoğu Anadolu'da uygulayarak, birçok Kürt aşireti reisini para karşılı̆̆ ele geçirmişti. Noel, Ali Galip'le birlikte, Erzurum Kongresi'nin toplanmasını engellemeye çalışarak ${ }^{82}$ Sivas Kongresi'ni basarak, Mustafa Kemal ve arkadaşlarını tutuklama hatta öldürme planı yapmışlardı. ${ }^{83}$ Filistin

${ }^{77}$ Paul Kennedy, Büyük Güclerin Yükselis ve Cöküsleri, (1500'den 2000'e Ekonomik De ğişme ve Askeri Çatışmalar), Çev. Birtane Karanakçı, 7.b., Ankara, Türkiye İş Bankas Kültür Yayınları,1998, s.325; Sina Akşin, Ístanbul Hükümetleri ve Milli Mücadele, c. I, Mutlakıvete Dönius, 1918-1919, İstanbul, Türkiye İs Bankası Kültür Yayınları, 1998, s. 166; Turan, a.g.c., s.141. Geniş bilgi için bkz. Armaoğlu, a.g.e., ss.145-148; Uçok, a.g.e., ss. 315321. "...Mezopotamya, sonra Irak adını alacak, doğudaki devlet, Ingiliz mandast (sömürgesi) altında Serif Hüseyin'in oğlu Kral Faysal (Birinci Dünya Savașı'nda Filistin Cephesi 'nde Osmanli'ya karş yapılan Arap Ísyanı'nda Arap Ordusu Komutanı) yönetiminde bir monarşi oldu" Bernard Lewis, Orta Doğu, Heristiyanlığın Doğuşundan Günümüze Orta Doğu'nun 2000 yıllık Tarihi, Çev. Mehmet Harmancı, 2.b., Istanbul, Sabah Yayınları, 1999. s. 278

${ }^{78}$ Turan, a.g.e., s.104.

${ }^{79}$ Hacettepe Üniversitesi, a.g.e., s.164

कo Öke, Musul-Kürdistan Sorunu, s.60.

${ }^{81}$ Binbaşı Noel, 23 Mayıs 1919'da Mardin'e, 14 Haziran 1919'da Diyarbakır’a uğramıs ve 23 Temmuz 1919'da Halep'e dönmüștü. Noel, 21 Ağustos 1919'da Halep'ten hareket ederek, Antep-Urfa-Diyarbakır yoluyla 31 Ağustos 1919'da Malatya'ya gelmişti. Uğur Mumcu, Kürt-İslâm Ayaklanmasi, 1919-1925, 17.b., Ankara, Tekin Yayınevi, 1995, s.17; Öke, Musul-Kürdistan Sorunu, s.79. Mustafa Kemal Paşa ve arkadaşları, 30 Ağustos 1919'da Erzurum'dan, 31 Ağustos 1919'da Erzincan'dan Sivas'a hareket etmişlerdi. Binbaşı Noel ve Mustafa Kemal Pasanın aynı tarihlerde Anadolu'da bulunmaları ve ters istikametlerden bir birlerine paralel güzergâhları izlemeleri İngilizlerin Milli Mücadele'yi özellikle Mustafa Kemal ve Silah Arkadaşlarını çok yakından takip ettiklerini göstermektedir.

82 İstanbul Hükümeti tarafından görevlendirilen Elazı ̆ Valisi Ali Galip, Elazığ, Diyarbakır ve Mardin'den seçilen az sayıda delegenin Erzurum Kongresi'ne katılmasına cngel olmuştu. Akşin, a.g.e., c. I, s.471.

${ }^{83} \mathrm{Gcnis}$ bilgi için bkz. Akşin, a g e. c. I, ss 540-554. Dahiliye Nezareti, Sivas Valiliğine 31 Temmuz 1335 (13 Ağustos 1919)'te gönderdiği telgrafta: "Mustafa Kemal ve Rauf Beylerin oralarda (Sivas'ta) bulunduklart taktirde hemen yakalanarak Dersaadet (İstanbul'un adlarından biri)'e gönderilmelerini" istemisti. Ankara Üniversitesi Türk Inkılâp Tarihi Enstitüsï Arşivi, K.19, B.48. Sivas Valiliği Dâhiliye Nezareti'ne: "Ali Galip Bevin Sivas'a gelmek üzere Malatya'da eskzyadan baz kimseleri yanına toplamast mesulivetini kabul edemeyeceğini, isten cekilmek üzere kime vekâlet birakmast gerektiğinin bildirilmesi cevabını vermişti, a.g.a., K.17, B.7. Mustafa Kemal, Paşa Dahiliye Nazırı Adil Beyden 11 
Cephesi'nde, Arap İsyanı'nın mimarı olan Lawrence'in, Arapları aleyhimize kışkırtmak için neler yaptığını çok iyi bilen Mustafa Kemal, Noel ve Ali Galip'in yakalanması için emir vermiştir. Noel ve Ali Galip, canlarını zor kurtararak, Anadolu'dan Suriye'ye kaçmıșlardır. ${ }^{84}$

İtilaf Devletleri, Mondros Mütarekesi'nden sonra, Anadolu'nun güneyinde de askeri harekâtlarını sürdürüyorlardı. İngilizler; Musul, İskenderun, Kilis, Maraş ve Urfa'yı, Fransızlar; Adana, Mersin ve Osmaniye'yi işgal etmişlerdi. İtilaf Devletleri, böylece Sykes-Picot Antlaşması'nı Anadolu'da da yürürlüğge koymuşlardı. İngiltere ve Fransa, 15 Eylül 1919'da Orta Doğu'yu paylaşma konusunda yeni bir antlaşma imzalamışlardı. İngiltere ve Fransa'nın 9-16 Mayıs 1916'da imzaladıkları Sykes-Picot Antlaşması'nda düzenlemeler içeren bu antlaşmaya göre: “Suriye, Lübnan ve Güney Anadolu Fransa'nın, Mezopotamya Musul dahil, Filistin ve daha güneydeki Osmanlt topraklart Ingiltere'nin mandast olacakttr. Ingilizler daha önce işgal ettikleri Maraş, Urfa ve Antep'i Fransızlara teslim edeceklerdir." ${ }^{85}$ Paris Barıs Konferansı'nda, ABD'ye Türkiye ve Ermenistan üzerinde manda önerildiğinde, Amerikalılar Türkiye'ye General James G. Harbord başkanlığında bir kurul göndermişlerdi. General Harbord, 20 Eylül 1919'da Sivas'ta Mustafa Kemal Paşa ile görüşmüştü. ${ }^{86}$

Fransızlar 11 Şubat 1920'de Maraş'ta mağlup olmuşlardı. Lord Curzon'un gayretiyle 21 Şubat 1920'de, İtilaf Devletleri temsilcileri Londra'da toplanmışlardı. İngilizler, Türklerin Trakya ve İstanbul'dan tamamen çıkartılmasını istemişlerdi. İtilaf Devletleri, 5 Mart 1920'de yapılan toplantıda, İngiliz Başbakanı Llyod George'un israrıyla İstanbul'un işgalini kararlaştırarak, 16 Mart 1920 'de şehri fiilen işgal ettirmişlerdi. ${ }^{87}$

Ağustos 1335 ( 24 Ağustos 1919)'te: “Ali Galip ve ayn halde olanlarm vaatlerine kanmanin Mr. Noel gibilerine vicdanlartnt satmanın getireceği sorumluluğun göz önünde bulundurulmasıme" istemiști. a.g.a., K.17, B.1.

${ }_{84}$ Atatürk, Nutuk, s.9; Öke, Musul Kürdistan Sorunu, s.122; Akșin, a.g.e., c. I, s.553; Çetiner, a.g.e., ss.167-174; Selek, Anadolu Ihtilali, c.I, ss. 287-288; Volkan, a.g.e.,s.200. Mustafa Kemal, Büyük Millet Meclisi'nin açılışının ertesi günü 24 Nisan 1920 'de, milletvekillerine hitaben yaptı̆̆ı konusmada. olayı şöyle anlatmaktadır:"Hakikaten Ingilizler daha evvel bütün Kürdistan't iğfal etmek. Türk vesair dindaslarından aytrmak için, tasavvur edebildikleri her sevi orada tatbikle mesgul idiler. Bu tatbikatta en büyük faaliveti gösteren. yüzbaș ve bir rivavete göre binbaș rütbesine haiz birisiydi ve buna maattessüf ( vazk ki) Islamlar dan bir iki kiși muavenet(yardım) ediyorlardı. Tam bu esnada. Noel dahi Malatya ya gelmis ve Ali Galip Bevle tesriki mesai eylemiști. Sivas istikametine tahriki tasavvur edilen kuvvetin bastinda bulunuyordu... Kongre kendisini serbest telakki ettikten sonra, bittabi Mister Noel ve Ali Galip Beye ve onun iğfal ettiği masum insanlara karşı tedabir (tedbirler, ölemler)., ittihaz etti(kabul etti)...Bütün o caniler (cinavet islevenler) valnzz kaldılar ve oradan firar etmeye (kacmava) muvaffak oldular." Atatürk'ün Söylev ve Demecleri, c. I, ss.32-33.

Belen, a.g.e., c.V, s.220; Volkan, a.g.e., s.204; Turan, a.g. e., s.149

${ }^{86}$ Bilge Criss, İsgal Altında İstanbul. 6.b.. İstanbul, İletișim Yayınları, 2007, s.87.

Çetiner, a.g.e., s.218. 
Mustafa Kemal Paşa, 18 Ocak 1919'da başlayan Paris Barış Konferansı'yla 16 Mart 1920'de İstanbul'un işgaline kadar geçen süre içinde; 19 Mayıs 1919'da Samsun'a çıkmıs, 21-22 Haziran 1919'da Amasya Genelgesi'ni yayımlamış, 23 Temmuz-7 Ağustos 1919'da Erzurum, 4-11 Eylül 1919'da Sivas Kongreleri'ni yapmış, 20-22 Ekim 1919‘da Amasya’da Osmanlı Hükümeti adına Salih Paşa'yla görüşmüş, Sivas Kongresi kararlarını büyük ölçüde İstanbul Hükümeti'ne de kabul ettirmiş, 27 Aralık 1919'da Ankara'ya gelmiş, 28 Ocak 1920'de Osmanlı Meclis-i Mebusanı'nda kabul edilen Misak-1 Milli kararlarının 17 Şubat 1920'de yayımlanmasını sağlamıştır. ${ }^{88}$ Misak-1 Milli, yayımlandığı tarihten itibaren, Milli Mücadele hedefi haline gelmiştir. Misak-1 Milli, devletin ve milletin geleceğini, haklı ve devamlı bir barışa ulaştırabilmek için, gerekli olan asgari şartları kapsamaktadır ${ }^{89}$ Musul (Musul, Dohuk, Erbil, Süleymaniye ve Kerkük), Misak-1 Milli sınırları içersinde kabul edilmiştir. ${ }^{90}$

Misak-1 Milli'nin Osmanlı Meclis-i Mebusanı'nında kabul edilmesi, İstanbul Hükümeti'ni telaşa düşürmüştü. İtilaf devletleri bu kararlardan memnun olmamışlar, çoğunluğu Meclis-i Mebusan üyesi (Milletvekili) olan ve aralarında Rauf Bey (Orbay)’inde bulunduğu bazı milletvekillerini tutuklayarak Malta'ya götürmüşlerdi.9' Mustafa Kemal Paşa, 16 Mart 1920 'de İstanbul'un işgali ve İngilizler tarafından Milli Mücadele arkadaşlarının Malta'ya götürülmesi üzerine, Heyet-i Temsiliye adına 16-17

${ }^{88}$ Hamza Eroğlu, Türk Inkılap Tarihi. Yeniden Düzenlenmiş. Genişletilmiş Yeni Baskı, Ankara, Savaş Yayınları, 1990, s. 138; Göze, a.g.e., s.94; YÖK, a.g.e., S.82; Hacettepe, Üniversitesi, a.g.e., s.169; Fromkin, a.g.e., s.426, Geniş bilgi için bkz. Turan, a., g., e., ss.120-124.

${ }_{89}$ Meclis, sınırların gelecekte alacağı şekli, Misak-1 Milli (Milli yemin, Milli Ant)'nin 1. maddesinde söyle açıklamıștır: "30 Ekim 1918 günkü Silah Bırakısıımı (Mondros Mütarekesi) yapıldı̆̆ı strada, Osmanlı Devleti nin, özellikle Arap çoğunluğunun yerleşmis olduğu, düşman ordularının işgali alında kalan kesimlerinin geleceğinin, halklarının serbestçe açılayacakları oyları uvarınca helirlenmesi gerekir; söz konusu Silah Bırakısımı (Mondros Mütarekesi) çizgisi içinde, din, soy ve amaç birliği bakımından birbirine bağlt olan, karşllıklt saygı ve özveri duygular besleyen soy ve toplum iliskileri ile çevrelerinin kosullarına tam saygılı Osmanlı İslam coğunluğunun verlesmis bulunduğu kesimlerin tümü. hakikaten veya hükmen hiçbir nedenle birbirlerinden ayrlamayacak bir bütündür..." Şimşir, Türk-Irak Ilişskilerinde Türkmenler, ss.50-51; Eroğlu, a.g.e., s.138; Şimşir, Atatürk ve Cumhurivet, s.230.

${ }^{90}$ Hacettepe Üniversitesi, a.g.e., s.275. David Frmkin’e göre: “...Musul'un stratejik önemi burasının Irak'a katılmasın gerektirivordu. Ayrıca. bölgede önemli petrol yatakları bulunması olasılığı da bunu arzulanır kılıyordu. Ancak Musul, Kürdistan olduğu düşünülen bölgeye dahildi ve Arnold Wilson, kendi yönetimine verilen savaş̧ı Kürtlerin yarım milyondan fazla oldukların ve Araplar tarafindan yönetilmeyi hiçbir zaman kabul etmeyeceklerini" iddia etmiştir. Fromkin, a.g.e., s.448. Bu tartışmalardan, Ingiltere' nin, Milli Mücadele devam ederken Sevr Antlaşması'na göre, Güneydoğu Anadolu'da sözde bir Kürdistan devleti oluşturmayı, daha sonra Musul'u mandası olan Irak'in sınırları içine dahil ederek, Irak'ın kuzeyinde özerk, federasyon veya bağımsız bir Kürt devleti kurmayı uzun vadede ise iki Kürt devletini birleştirerek "Büyük Kürdistan" 1 gerçekleştirmeyi planladığı anlașılmaktadır.

${ }^{\text {y1 }}$ Çetiner , a.g.e., ss. 221-222. 
Mart 1920 tarihlerinde Kolordu Komutanlarına ve Valilere "...Rehin olarak Ingiliz. Kontrol subaylart tevkif edilecektir (tutuklanacakttr)" emrini vermiş, bunun üzerine bazı İngiliz subayları tutuklanmıștır. Mustafa Kemal'in aldığı tedbirler, İngilizler tarafından tutuklanarak Malta'ya götürülen Meclis-i Mebusan üyelerinin daha sonra serbest bırakılmasını sağlamıștır. ${ }^{92}$ İngiltere'nin, savaş giderleri, 1918'e gelindiğinde toplam devlet harcamalarının \%80'ini, Gayri Safi Milli Hâsılası (GSMH)'nın \%52'sini kapsamaktaydı. Mustafa Kemal, İngiltere'nin önce Musul'u, sonra İstanbul'u işgal etmesine rağmen, ekonomik savaşı sürdürmesinin mümkün olamayacağını değerlendirmiş ve adeta rest çekmiştir. ${ }^{93}$

İtilaf Devletleri, Birinci Dünya Savaşı sona erdikten sonra, Osmanlı topraklarını paylaşmak, Orta Doğu'yu yeniden yapılandırmak, Doğu Anadolu'da bir Ermenistan devleti, Güneydoğu Anadolu'da ise bir Kürdistan devleti kurulmasının ön koşullarını hazırlamak amacıyla, Londra ve SanRemo konferanslarını düzenlemişlerdir. İtilaf Devletleri temsilcileri, Osmanlı Devleti hakkında karar vermek amacıyla, 18 Nisan 1920'de SanRemo'da tekrar toplanmışlardı. Türk Diplomatı Galip Kemal Beyin, 23 Nisan 1920 tarihli Türkiye'den koparılması düşünülen bütün vilayetlerde Türk nüfusunun mutlak çoğunlukta olduğunu belirten telgrafını ve $A B D$ Başkanı Wilson'ın Prensiplerini hiç dikkate almadan, 26 Nisan 1920'de, Osmanlı İmparatorluğu'yla yapılacak barışın şartlarını şöyle tespit etmişlerdir: "Istanbul ve Boğazlar milletlerarası bir idareye birakllacak, Irak ve Filistin'de Ingiliz mandast, Güneydoğu Anadolu'da İtalyan ve Fransız nüfuz bölgeleri, Ingilizlerin himayesinde bir Kürt özerk bölgesi kurulacak, Doğu'da altı vilayet (Erzurum, Van, Bitlis, Diyarbakır, Elazı ğ, Sivas) Ermenilere, İzmir'le Batı ve Doğu Trakya Yunanistan'a verilecek, kapitülasyonlardan bütün Itilaf Devletleri yararlanacaktır."

İtilaf Devletleri, San Remo'da alınan kararları bildirmek üzere, Osmanlı Heyeti'ni 22 Nisan 1920 'de İtalya'ya davet etmişlerdir. Türk Heyeti barıș şartlarını ağır bulduğundan, 11 Mayıs, 2 Haziran ve 20 Haziran 1920'de yapılan toplantılardan bir sonuç alınamamıştır. İtilaf Devletleri, San-Remo kararlarına işlerlik kazandırmak amacıyla, Yunan kuvvetlerine Milne Hattı denilen Manisa-Ayvalık hattından doğuya geçme izni vermişlerdir. Yunan Kuvvetleri, 22 Haziran 1920'de taarruza geçerek Salihli, Akhisar, Alaşehir, Balıkesir, Bandırma, İznik ve Bursa'yı işgal etmişlerdir. ${ }^{95}$ Prof. Dr. Hamza Eroğlu'na göre: "Bu taarruzun hedefi, Sevr'in idam hükmünü kolaylıkla

\footnotetext{
${ }^{92}$ Selek, Anadolu İhtilali, c. I, s.328.

${ }^{93}$ Kennedy, a.g.e., s.630.

${ }^{94}$ Volkan, a.g.e., ss.231-232; Turan, a.g.e., ss.144-145. Üçok, a.g.e., s.320. San-Remo Konferansı'nda Fransa, Ingiltere'nin kendisini Orta Doğu'da desteklemesi karşıllı̆ında Musul'u Ingiltere'ye bırakmıștır. Armaoğlu, a.g.e., ss.321-322.

${ }^{95}$ YÖK, a.g.e., c. I/I, s.124.
} 
uyguiama imkânını hazırlamak ve antlaşma tasarısında herhangi bir değişikliği mümkün kllmamaktl.,"96

İstanbul Hükümeti, 10 Ağustos 1920'de İtilaf Devletleri'yle hiçbir zaman yürürlüğe giremeyecek olan Sevr Antlaşması'nı imzalamıştır. ${ }^{97}$ Kazım Karabekir Paşa, 17 Ağustos 1920'de, TBMM Başkanlığı'na gönderdiği telgrafta; Sevr Antlaşması'nı uygun gören Şura-i Saltanat üyeleri ile imzalayan heyet üyelerinin vatan haini ilan edilerek cezalandırılmalarını talep etmiştir. ${ }^{98}$ TBMM, 19 Ağustos 1920 'de, konuyla ilgili yaptı̆g 1 toplantıda; Sevr Antlaşması'nı imzalayanları, bunu onaylayan Şura-i Saltanat üyelerini vatana ihanetle suçlayarak, vatansız sayılmaları kararını almış, ayrıca bu antlaşmayla kendini bağlı görmediğini bütün dünyaya ilan etmişti. ${ }^{99}$ Sevr Antlaşması'nı gerçekleştirmek amacıyla, batıdan Yunanlılar ilerlerken. Ermeniler de çıkan fırsatı değerlendirerek, Doğu Anadolu'daki saldırılarını yoğunlaştırmışlardır. Ermenilerin Misak-1 Milli sınırlarını ihlal etmeleri üzerine Kazım Karabekir Paşa, 28 Eylül 1920'de karşı taarruza geçmiş, Kars, Arpaçay ve Gümrü'yü ele geçirmişti. Barış istemek zorunda kalan Ermenilerle 2/3 Aralık 1920'de Gümrü Antlaşması imzalanmış, Kars, Sarıkamış, Kağızman ve Iğdır geri alınmıştı. Gümrü Antlaşması, Misak-

${ }^{x}$ Eroğlu, a.g.e., s.149

$"$ Tamamı 433 madde ve 150 sayfa olan Sevr Antlasması'na göre: “' Ingiliz Hükümeti ve Bağlaşıkları Ístanbul'u ve Boğazlar' ' isgal edecekler, uluslar arası bir komisyon buraların kontrol ve yönetimini üzerine alacak. Yabancıların hukuki güvenliğini sağlamak için kapitülasvonlar yeniden yürürlüğe girecek. Osmanlı Imparatorluğu askeri ve mali kontrol altına konulacak, askerlik hizmeti kaldırılacak, yalnız 50.700 kişilik bir ordu olacak, savas gemisi ve uçak yaptlmayacak. Limanlar, Irmaklar ve demiryolları uluslar arası kontrole tabi tutulacak. Türkive onarım( tazminat) ödevecek, ulusal ve dini azılıkları Uluslar Kurumu'nun koruvuculuğu altına koyacak. Osmanlı Imparatorluğu parçalanacak, şöyle ki: Gelibolu'yla birlikte Catalca cizgisine kadar Trakva, bütün Ege Adalart (Italya'ya verilen 12 Ada hariç ve İzmir bölgesi Yunanistan'a, Surive ve Lübnan Fransa'ya, Irak (Musul dâhil) ve Filistin ingiltere 'ye, Edremit'ten Kilikya (Adana) stmırına kadar oldukça derin bir kıyı bölgesi ve bu arada özellikle Antalya Italya'va verilecekti. Doğu illerinde bağımsız bir Ermenistan kurulacak. Güneydoğu illerine de Kürdistan adı altında özerklik verilecekti." Ücok,a.g.e., ss.320-321; Turan, a.g.e., ss.146-147; Volkan, a.g.e., s.235; Eroglu, a.g.e., ss.149-150; Hacettepe Üniversitesi, a.g.e., ss.183-184. Lewis, Modern Türkiye'nin Doğusu, s.247; Aydemir, Tek Adam, c.II, ss.387-390. TBMM Hükümeti, İstanbul'un resmen işgal edildiği 16 Mart 1920 'den itibaren, İstanbul Hükümeti tarafindan imzalanan antlaşmaları tanımayacağını ilan ettiğinden Sevr'i de tanımamıștır. Volkan. a.g.e.s.233.

${ }^{48}$ Kazım Karabekir Paşanın 17 Ağustos 1920 tarihli teklifi şöyledir: "Vatansız ve vicdansız üc serserinin, yine kendileri gibi millet ve vatanla alakası olmayan bir kaç kişi adına barıs antlasmasını imza ettiklerini ajansta gördük. Milli Mücadelemize daha büyük bir azım ve imanla devam edeceğimize ahdettiğimizi arz eylerim. İstanbul'da kuruluşunu daha önce duvduğumuz Sura-i Saltanat'ta Türkiye'nin hayati mevcudiyetini söndüren bu untlasmanin imza edilmesini kararlasturan sahıslarin ve antlasmaya imza atanların, vatana ihanetle itham olunmasın ve haklarında gıyabi hüküm verilmesini, bu vatansızların isimlerinin her yerde lanetle anılmasım ve duyurulmasım arz ve teklif ederim." YÖK, a.g.e., c. I/I. s. 119; Eroğlu, a.g.e., s.149; Selek, Anadolu Ihtilali, c. I, s.344

${ }^{*}$ Çetiner, a.g.e., s. 234; Turan a.g.e., s. 147; Volkan, a.g.e., s.235. 
Milli'de belirtilen doğu sınırının tespiti ve TBMM Hükümeti'nin imzaladığı ilk antlaşma olması açısından önem kazanmıştır. ${ }^{100}$

\section{Mudanya Mütarekesi'ne Giden Yol}

İngiltere ve Fransa, Sevr Antlaşması'nın şartlarını TBMM Hükümeti'ne de kabul ettirmek amaciyla, Yunan Kuvvetlerini, 6 Ocak 1921'de, Bursa'dan Eskişehir istikametine hareket ettirmişlerdi. Genelkurmay Başkanı aynı zamanda Batı Cephesi Komutanı Albay İsmet (İnönü) ve Güney Cephesi Komutanı Albay Refet (Bele) tarafından 8 Kasım 1920'de kurulmaya başlanan Düzenli Ordu, Yunan Ordusunu İnönü'de karşılamıș ve 11 Ocak 1921 'de durdurmayı başarmıștı. ${ }^{101}$ İtilaf Devletleri, Birinci İnönü Muharebesi'nden sonra, Sevr Antlaşması'nın şartlarını yeniden gözden geçirmek üzere, Londra'da bir konferans toplamaya karar vermişlerdi. Londra Konferansı, 21 Şubat-12 Mart 1921 tarihleri arasında İngiltere'de yapılmıştır. ${ }^{102} \mathrm{Bu}$ Konferans'a, Osmanlı Hükümeti adına Sadrazam Tevfik Paşa ve TBMM Hükümeti adına Dışş̧leri Bakanı Bekir Sami Bey katılmışlard.. ${ }^{103}$ Türk Milleti adına Osmanlı Hükümeti Heyeti'ne söz verildiğinde, Sadrazam Tevfik Paşa: "Söz hakkı milletin gerçek temsilcilerinindir" diyerek, fevkalade bir jest yapmıs, İtilaf Devletleri'ni şimdiye kadar tanımak istemedikleri TBMM Hükümeti'yle direkt olarak muhatap olma durumunda bırakmıştır. ${ }^{104}$ Londra Konferansı'nın şartları, Sevr Antlaşması'nın şartlarını biraz yumuşatıyor, ancak temel esaslarını muhafaza ediyordu. ${ }^{105}$ Konferans Heyetimiz: "Bu teklifi kabul etmeyeceğini, kabul edebilece ği asgari sartların Misak-ı Milli Projesi olduğunu" İtilaf Devletleri'ne bildirmiști. İtilaf Devletleri temsilcileri, Ankara Heyeti'nin isteklerini: Yunanlıların İzmir'i boşaltmalarını, Boğazlar üzerinde Türklerin yeniden egemen güç konumuna gelmesini, İstanbul'daki tüm yabancı askerlerin derhal şehri boşaltmasını alayla karşılamışlardı. ${ }^{106}$ Londra Konferansı görüşmeleri, hiçbir konuda sonuç alınamadan sona ermiş olmasına rağmen ${ }^{107}$ TBMM Hükümeti'nin Konferans'a çağrılması Milli Mücadele'nin İtilaf Devletleri'ne karşı politik alanındaki başarısının başlangıcı olarak kabul edilmiştir. ${ }^{108}$ TBMM Hükümeti Dıșişleri Bakanı Bekir Sami Bey, İngiltere, Fransa ve İtalya ile ikili antlaşmalar imzalamıştı.

${ }^{10}$ A. Mete Tuncoku, Türk Tarihi İçinde Atatürk ve Cumhurivet, Ankara, Gnkur. ATASE Bşk.lığı Yayınları, 2001, s.74; Turan, a.g.e., ss. 155-156.

${ }_{101}$ Selek, Anadolu İhtilali, c. II, s. 469; Volkan, a.g.e., s. 238.

${ }^{102}$ Atatürk, Nutuk, s. 424

${ }^{103}$ Lord Kinross, Atatürk, Bir Milletin Yeniden Doğuşu, Çev.Necdet Sander, 14.b., İstanbul, Altun Kitaplar, 2003, s.311.

${ }^{104}$ Selek, Anadolu İhtilali, c. II, s.543; Turan, a.g.e., s.163

${ }^{105}$ Kinross, a.g.e., ss.312-313; Eroğlu, a.g.e., s.178.

${ }^{106}$ Volkan, a.g.e., s. 239.

107 Atatürk, Nutuk, s. 424; Göze, a.g.e., s. 141.

${ }^{108}$ Eroğlu, a.g.e., s.178; Volkan, a.g.e., s.237. 
Bu antlaşmalarda, Misak-1 Milli'nin ruhuna aykırı hükümler bulunuyordu. Mustafa Kemal, bu konu hakkında şu hususları belirtmiştir:

"Baylar, Ittilaf Devletleri'nin, Londra'ya barış yapmak için gönderdiğımiz Delegeler Kurulumuz Başkanı Bekir Sami Beye imza ettirdikleri sözleșmelerle, Sevr tasarısından sonra aralarında yaptıkları 'Ü̧̧ї Antlaşma' adl verilen ve Anadolu'yu sömürme (nüfuz) bölgelerine ayıran anlaşmayl, başka adlar altında, ulusal hükümetimize kabul ettirmek amacını güttükleri apaçık bellidir. İtilaf siyasa adamlar bu isteklerini Bekir Sami Beye kabul ettirmeyi de başarmışlardır... Bekir Sami Beye, görüslerinin yersizliğıini kendim söyleyerek Dışişleri Bakanlığından çekilmesini önerdim. Bekir Sami Bey, bu önerimi kabul ederek çekilme yazısınt verdi." ${ }^{109}$

Londra Konferansı'ndan dört gün sonra düzenlenen Kahire Konferansı'nda, Fransızlar tarafından Suriye'den kovulan Faysal'ın Irak Kralı olması uygun görülmüştü. ${ }^{110}$ Londra Konferansı'yla; İtilaf Devletleri, TBMM Hükümeti'ni resmen muhatap olarak kabul etmek durumunda kalmış, ancak, Misak-1 Milli'yi kabul etmemişlerdi. Bunun üzerine, TBMM Hükümeti, Rusya ile 16 Mart 1921'de Moskova Antlaşması'nı imzalanmıştı. ${ }^{111}$ Moskova Antlaşması'yla doğu sınırlarımızın güvenliği ve Rusya'nın desteği sağlanırken, Kafkas Cephesi'ndeki birlik, silah, araç, gereç ve malzemenin Batı Cephesi'ne kaydırılarak Yunanistan'a karşı sıklet (ağırlık) merkezi yapılması sağlanmıştır. İtilaf Devletleri, Londra Konferansı'nda Türk Heyeti'ne bir aylık süre vermelerine rağmen, daha cevabını beklemeden Yunan kuvvetleri, 23 Mart 1921'de İnönü mevzilerine tekrar taarruza başlamışlardı. Batı Cephesi Komutanlığının 1 Nisan 1921'de

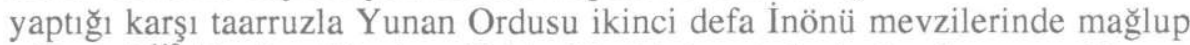
edilmişti. ${ }^{112}$ Tarihe Kütahya-Eskişehir Muharebeleri olarak geçen Yunan Ordusunun 10 Temmuz 1921 'de başlattığı taarruz, Türk Ordusunun 25 Temmuz 1921'de Sakarya Nehri doğusuna çekilmesi ile sonuçlanmıştı. 23

${ }^{109}$ Mustafa Kemal, Bekir Sami Beyin, Avrupa'daki yolculuğu sırasında yaptığı çeşitli buluşmaların kendisinde bıraktığı izlenimlere dayanarak, İtilaf Devletleri’yle ilkelerimize uygun olarak (Misak-1 Milli) anlaşma yolunun bulunduğu düşüncesinde direnmesi üzerine, ona yazdığı mektupta: “...Bu ilkelerin özü, ş kısa tümce ile anlaşılabilir: Bilinen ulusal sınırlarımız içinde ülkemizin bütünlüğünü ve ulusun tam bağımsızlığını sağlamak...Türkiye Büyük Millet Meclisi, İtilaf Devletleri'nin bu eğilimini gösterecek güvenilir, içtenlikli belirti ve sonuçlart şimdilik görmemektedir..." düşüncesini yenilemiştir. Atatürk, Nutuk, ss.432-433.

${ }_{110}$ Ergene, a.g.e., s.107. Fransa, 26 Temmuz 1920'de Şam's işgal ederek ertesi gün Faysal'ı Londra'ya sürgüne göndermisti. İngiltere Basbakanı Lloyd George'dan Kahire'deki Churchill'e: "Durumu mütemadiyen Fransa'ya çıtlattık... Halk tarafindan desteklendiği sïrece, Faysal Irak için münasiptir" mesajını göndermiş, Churchill de 18 Mart 1921 'de: "Faysal Formülï"nün uygun olduğunu bildirmistir. Faysal, 23 Ağustos 1921 'de Irak Kralı olmuştur. Wistone, a.g.e., ss.467-468; Yergin, a.g.e., s.230. Yeni krallığın adı Mezopotamya'dan Irak (köklü ülke)'a dönüștürülmüștür. Fromkin,a.g.e., s. 509.

${ }^{11}$ Geniş bilgi için bkz. Turan, a.g.e., ss. 162-166.

112 Aydemir, Tek Adam, c.II, ss.437-438. 
Ağustos-13 Eylül 1921 tarihleri arasında cereyan eden Sakarya Meydan Muharebesi'nde Şark Meselesi'nin Anadolu harekâtı durdurulmuştu. ${ }^{113}$

Sakarya Meydan Muharebesi'nden sonra, Rusya'nın da onayı ile Azerbaycan, Gürcistan ve Ermenistan ile 13 Ekim 1921'de Kars Antlaşması'nı imzalamıștı. Yapılan bu antlaşmalarla Türkiye'nin Gürcistan, Ermenistan ve Azerbaycan devletleriyle bugünkü sınırları çiziliyordu. Fransa, Sakarya Meydan Muharebesi'nden sonra, TBMM Hükümeti'yle 20 Ekim 1921'de Ankara İtilafnamesi'ni imzalamış, Hatay hariç halen geçerli olan Suriye sınırımız çizilmişti. Böylece Fransa, Ankara İtilafnamesi'yle Türkiye'nin Misak-1 Millî sınırlarını (Hatay hariç), bu sınırlar içersinde yeni bir Türk Devleti'nin kurulmasını kabul ediyordu. İngilizlerle 23 Ekim 1921 'de antlaşma sağlanarak, Mondros Mütarekesi'nden sonra Malta'ya götürülen esir Türklerle Anadolu'da tutuklu bulunan İngilizlerin değiştirilmesi kararlaştırılmıştı. Ankara Hükümeti, Sakarya Meydan Muharebesi'nden sonra, İtilaf Devletleri'yle yaptığı bu antlaşmalarla, Türk Milleti'nin haklı mücadelesini tüm dünyaya anlatmak fırsatını bulmuştur. ${ }^{114}$ Churchill, Ankara Antlaşması'ndan Musul adına büyük endişe duymuş, Türkiye'nin, Fransa'yla anlaşarak, Bağdat Demiryolu'nu kullanmak suretiyle, Faysal'ın hassas rejimine saldırmasından korkmuş ve bu durumu müttefiki Fransa'ya karşı bir savaş nedeni sayacağını ilan etmişti. ${ }^{115}$ Mustafa Kemal, Milli Mücadele süresince İngiltere ve Fransa ile ayrı ayrı ikili antlaşmalar imzalayarak, TBMM Ordularına karşı güç birliği yapmalarını önleyici politika uygulamıştır. ${ }^{116}$

Sakarya Meydan Muharebesi'nde başarılı olamayan Yunanlılara bazı avantajlar sağlamak amacıyla, İtilaf Devletleri 22 Mart 1922'de Türkiye ve Yunanistan'a mütareke şartlarını bildirmişlerdir. Türkiye'nin cevabının bildirilmesine vakit kalmadan, Paris'te toplanmış bulunan İtilaf Devletleri Dışişleri Bakanları, 26 Mart 1922'de tekrar barış teklifinde bulunmuşlardır. İleri sürülen barış şartlarına göre; Londra Konferansı'nda olduğu şekilde Sevr Antlaşması'nın esası korunuyordu. Millî Hükümet, 5 Nisan 1922'de yaptığ ${ }_{1}$ teklifte, Yunan ordusunun mütarekenin imzalanmasından başlayarak 15 gün içinde Eskişehir-Kütahya-Afyon hattından, dört ay içinde İzmir dâhil olmak üzere bütün Anadolu'dan çekilmesini istemiştir. Bu hususlar kabul

\footnotetext{
${ }^{113}$ Geniş bilgi için bkz. a.g.e., ss. $441-452$.

${ }^{114}$ Turan, a.g.e., s.173.

115 Churchill, 26 Ekim 1921 'de Kabine'ye Fransa'nın Kemalistlere yardım ettiğini bildirdiği bir muhtırada şöyle yazmıștır: "Bu habere inanmak çok güc. Ancak, eğer doğruysa. bu Fransa Hükümeti'nin diplomasi dilinde ancak 'dostça olmayan davranış' olarak nitelendirilebilecek bir seyden suçlu olduğunu göstermektedir. Diplomasi dilinde: 'bir devlet diğer devletleri yaptıkları belirli bir hareketin savasa yol açacă̆ı konusunda uvarmak isterse. genellikle bu hareketin 'dostça bir davranıs olmadığım' belirtir." Fromkin, a.g.e., s.540.

${ }^{16}$ David Fromkin'e göre: "Ingiltere'nin bu diplomatik yalnızlığı, bir dereceye kadar. Mustafa Kemal'in usta diplomasisi sayesinde olmuştur. Ankara rejimi iki müttefiki bilerek birbirine düşürmüş̧ürr." Fromkin, a.g.e., s. 541.
} 
edildiği takdirde, üç hafta içinde Türk delegasyonunun kararlaştırılan şehre gönderileceği bildirilmişti. İtilaf Devletleri 15 Nisan 1922 tarihli cevaplarıyla Türkiye'nin teklifini reddetmişlerdir. ${ }^{117}$

İngiltere, Türkiye'nin yakın bir tarihte Yunan Ordusuna karşı taarruza geçebileceği, Türkiye'nin Rusya'yla olan ilişkilerinin nasıl gelişeceği ve Türkiye'nin Irak'a karşı askerî bir harekât yapabileceği ihtimalleri üzerinde duruyor, bu gelişmelerin çıkarlarını olumsuz etkileyeceğinden endişe duyuyordu. ${ }^{118}$ Mustafa Kemal, Lozan Barış Antlaşması öncesi yapılan barış girişimlerinden, Türkiye lehine bir sonuç çıkmayacağını tahmin etmiş, 20 Ağustos 1922'de Ankara'dan Akşehir'deki Batı Cephesi Karargâhı'na gelerek, kısa bir görüşmeden sonra, 26 Ağustos 1922 sabahı düşmana taarruz emrini vermiştir. ${ }^{119}$ Türk Orduları, 30 Ağustos 1922'de Başkomutanlık Meydan Muharebesi'ni kazanarak, 9 Eylül 1922'de İzmir'e, 10 Eylül 1922'de Bursa'ya ulaşmışlardır. ${ }^{120}$ Türk Orduları, Yunan Ordularını Anadolu'dan attıktan sonra, İngiliz İşçi Partisi Lideri Mac Donald Parlamento'da yaptı̆̆ konușmada, Lloyd George hakkında: "Hazineden bu kadar para harcandı. Hani Anadolu taksim edilerek, hani Boğazlar bizim olacaktı! Gelsin hesap versin...!" demiş ve Başbakan Lloyd George'dan hesap sormuştur. ${ }^{121}$ Itilaf Devletleri'nin, 23 Eylül 1922'de askerî harekâtın durdurulması isteğine uyularak, 11 Ekim 1922'de Mudanya Mütarekesi imzalanmış, Doğu Trakya muharebe yapmadan kazanılmıştır. ${ }^{122}$

\section{Millî Mücadele'de Musul}

Mustafa Kemal'in, Batı Cephesi'nde Yunan Ordusu ile muharebeler devam ederken, Musul Meselesi'yle de çok yakından ilgilendiği görülmektedir. Mustafa Kemal, 1 Şubat 1922'de Millî Savunma Bakanlığı'na: "Faysal'ın Irak'ta hükümet kurmak, Ingilizler'in de Musul ilini siyasi manda altında bulundurmak isteği, yapılan siyasi faaliyetlerden anlaşılmaktadır. Bu sebeple esasen Misak-ı Millî sınırları içinde kalan Musul ilinin kurtarllmast amactyla, Revandüz bölgesine bir kısım kuvvet gönderilmesi" talimatını vermişti. ${ }^{123}$

Mustafa Kemal Paşanın talimatı üzerine, Suriye ve Antep bölgelerinde çeşitli görevler almış bulunan Kaymakam Özdemir Bey (Ali Şefik Özdemir) komutasında bir binbaşı, altı üsteğmen, altı teğmen, altı asteğmen, bir subay

\footnotetext{
${ }^{117}$ Selek, Anadolu Ihtilali, c. II, ss.676-677.

${ }^{118}$ a.g.e., s.676.

${ }^{119}$ Atatürk, Nutuk, s.493.

${ }^{120}$ Eroğlu, a.g.e., s.193; Selek, Anadolu Ihtilali, c.II, s.693: Göze, a.g.e., s. 279.

${ }_{121}$ Muzaffer Erendil, Il ginc Olaylar ve Anekdotlarla Atatürk, Ankara, Gnkur. Basımevi, 1988, s. 218; Gnkur. ATASE Bşk.lığı, Türk Istiklal Harbi, c.II, Ks. 6, 4. Kitap, Batı Cephesi. Istiklal Harbi nin Son Safhası, Ankara, Gnkur. Basımevi, 1995, s. 384.

${ }_{122}$ YÖK, a.g.e., c.1/1, s.167; Criss, a.g.e., s.216; Roux, a.g.e., s.239.

${ }^{123}$ Gnkur. ATASE Bşk.lığı, Türk Istiklal Harbi, c. IV. Güney Cephesi, Ankara, Gnkur. Basımevi, 1966, s.267: Öke, Musul-Kürdistan Sorunu. s.182.
} 
adayı ve bir hesap memurundan oluşan heyet Musul'u geri almak için görevlendirilmişti. Adı geçen heyet, aşiretlerden topladığı milisler, Fransız ordusundan kaçmış Tunuslu ve Cezayirli erlerle 22 Haziran 1922'de Irak'ın kuzeyinde bulunan Revandüz bölgesine ulaşmıştı. Özdemir Bey, 31 Ağustos'ta, İngilizlere karșı taarruza geçmiș. "Derbent Muharebesi"ni kazanarak, Musul'la irtibat kurmayı başarmıştı. Bunun üzerine. Musul'daki Kürt liderlerden Şeyh Mahmud ile irtibat kuran Özdemir Bey'e, yeni bir harekâta kadar elde ettiği mevzileri tutması emredilmişti. ${ }^{124}$

Mustafa Kemal Paşanın Batı Cephesi'nde Düzenli Ordu'yla Yunanlılara, Irak Cephesi'ndeyse milis güçleriyle İngilizlere karşı eş zamanlı olarak başlattığ $\breve{g}_{1}$ harekât, İngilizlerin Yunanlılara yapacağı askeri desteği azaltmıştır. Batı Cephesi'nde kazanılan başarı, Musul halkını da etkilemiş ve Türkiye'ye karşı sempati duymalarını sağlamıştır. Genelkurmay Başkanı Fevzi Paşa, 7 Eylül 1922'de Doğu ve El Cezire Komutanlıklarına çektiği telgrafta: "Musul'un silâhla alınacă̆ını" belirtmiştir. Harekât plânına göre: El Cezire Cephesi kuvvetleriyle, Dicle'nin iki tarafından Musul istikametinde taarruz edilecektir. Doğu cephesi ise Van, Hakkâri ve Iğdır sınır kıta'larından teşkil edilen dağ bataryalarıyla takviye edilen bir piyade tümeni, bir süvari tugayı, aşiret süvarileri ve yerli halkla takviye edilerek Özdemir Bey Müfrezesiyle koordineli olarak İmadiye-Süleymaniye hattı üzerinden Musul ve Kerkük'e taarruz icra etmek üzere görevlendirilecektir. ${ }^{125}$

İngiltere Başbakanı Lloyd George, 19 Ekim 1922'de istifa etmek zorunda kalmış, ${ }^{126}$ Mudanya Mütarekesi'nin imzalanarak, Doğu Trakya'nın savaş yapılmadan kazanılması, aynı yöntemle Musul'un da geri alınması umudunu artırmıștır. Ancak, İngiltere'nin Birinci Dünya Harbi'nden önce Hindistan yolu üzerinde bir üs olarak gördüğü Orta Doğu politikası, savaştan sonra:"Doğal kaynaklarıyla zengin, ekonomik bakımdan güçlü olan ve doğuyla ulaşım bağlantısı yönünden stratejik konumda bulunan bölgeleri (Orta Doğu'yu ve özellikle de Musul'u) elinde tutmak" olarak belirlenmiştir. ${ }^{127}$

${ }^{124}$ Öke, Musul-Kürdistan Sorunu, s.184.

125 a.g.e., s. 192.

126 Criss, a.g.e., s.216; Volkan, a.g.e., s.274. Lord Kinross'a göre: “ Lloyd George, istifa etmek zorunda kaldı. Başbakanlıktan ayrlltrken sekreterine. 'Bir daha burava ayak basmayacağım' dedi.' 'Ancak, Bonar Law'la Lord Curzon'dan, Gal bölgesi okuiları için bağıs istemeve gelirsem, o baska'. Bonar Law Başbakan oldu. Asi dive kücümsenen bir Türk. üç ylllı bir kavga sonunda. Ingiltere Hükümeti'ni ve ünlü Başbakan'n 'nevirmeyi başarmıştı. Romantik adam, gerçekçi adamın önünde silinip gitmiş; bir Makedonyalı bir Kelt'in strtını yere getirmisti.”. Kinross, a g.e., s.400.

${ }^{127}$ Mim Kemal Öke, Belgelerle Türk-Ingiliz Iliskilerinde Musul ve Kürdistan Sorunu. 1918-1926, Ankara, Türk Kültürünü Araştırma Enstitüsü Yayınları, 1992. s.2. Mim Kemal Öke’ye göre. "...Lloyd George kabinesinin düsmesiyle Türkiye' yle genel bir savasa girilmesi ihtimali de ortadan kalkacaktl... Bonar Law Hükümeti uzlaşmayt düşünüyordu. hatta Musul'dan toptan çekilmeyi bile göze almıșt.1922 ytlmın sonlarına doğru kabine. büyük 
Mustafa Kemal, 24 Ekim 1922'de United Press Muhabirinin: “...Petrol arazisini talep edecek misiniz?" sorusuna karşıllk: "Musul vilayeti, hudud-u millimiz dâhilindedir..." cevabını vermiştir. ${ }^{128}$ Alınan cevaplar çerçevesinde El Cezire Cephesi kıtalarının 10 Kasım 1922'ye kadar Siirt-DiyarbakırMardin-Cizre bölgesinde toplanması, Doğu Cephesi'nden gönderilecek kuvvetler gelince taarruza başlanması emredilmiştir. Türkiye Büyük Millet Meclisi Hükümeti'nin bu faaliyetlerinden, Lozan görüşmeleri başlamadan önce, Musul'un işgal edilmesini plânlandığı anlaşılmaktadır. Ancak, gerek Mudanya Mütarekesi'nin imzalanmış, gerekse Lozan Konferansı'nın başlayacak olması askerî yöntemlerden vazgeçildiğini göstermektedir. ${ }^{129}$

\section{Lozan Antlaşması'na Giden Yol}

Lozan Barış görüşmelerine; Türkiye, İngiltere, Fransa, İtalya, Japonya, Yunanistan, Romanya ve Yugoslavya (Sırp-Hırvat-Sloven Devleti), Rusya, Ukrayna, Gürcistan, Amerika Birleşik Devletleri (ABD), Belçika, Portekiz ve Bulgaristan katılmışlardır. Konferans, 20 Kasım 1922'de açılmış, görüşmeler 21 Kasım 1923 'te başlamıştır. ${ }^{130}$ TBMM, İsmet Paşa başkanlığında Trabzon milletvekili Hasan Bey ve Sinop milletvekili Rıza Nur Bey'den oluşan bir delegeler kurulu seçmiş, askerî, malî, iktisadî, hukukî müşavirler ve kâtiplerle birlikte İsviçre'nin Lozan şehrine gönderilmek üzere 40 kişilik bir heyet teşkil edilmişti. ${ }^{131}$ Hükümet, Türk Heyeti, Lozan Barış Konferansı'na giderken, Dışişleri Bakanı ve Baş delege (Baş murahhas) İsmet Paşaya (İnönü) üç sayfahık ve 14 maddelik bir hükümet talimatı vermişti. Her sayfasında Başbakan ve tüm Bakanların imzaları bulunan bu talimatın amacı, Misak-1 Milli kararlarının gerçekleştirilmesi, kurulacak yeni devletin tam bağımsızlığının ve egemenliğinin sağlanmasıyd ${ }_{1}{ }^{132}$ Mustafa Kemal, Lozan görüşmeleri devam erken 25 Aralık 1922'de, Le Journal Muhabiri Paul Herriot'ya Çankaya'da verdiği beyanatta Musul ile ilgili şunları söylüyordu:

ölçüde kendi kamuoyunun tazyikiyle (basktsıyla) Musul'u terke hazırlanacaktı. Ne var ki, petrolden de vazgeçmek pek zor bir karar olacakı. Curzon, bu konuda ă̆ırlığın Hükümet'e hissettirecek ve bilhassa petrolden feragat edilmemesini savunacakt. Kendisine en büyük desteği verenin Cox (Irak Genel Valisi) olduğu görülecektir." Öke, Musul-Kürdistan Sorunu, ss.181-182.

Atatürk'ün Söylev ve Demeçleri, c. III. s.69.

${ }^{129}$ Öke, Musul-Kürdistan Sorunu, s.192.

130 Harp Akademileri Komutanlığı, Lozan Antlasması, Montreux Sözlesmesi ve Paris Sözlesmesi, Istanbul, Harp Akademileri Basımevi, 1987, s. 1; Şimşir, Türk-Irak İlişkilerinde Türkmenler, s.53; Hacettepe Üniversitesi, a.g.e., s.221; YÖ, a.g.e., s.174; Selek, Anadolu Ihtilali, c.II, s. 697.

${ }_{13}$ Simşir, Atatürk ve Cumhuriyet, s.136; YÖK, a.g.e., c.I/I, s.175

132 Lozan Barıs Konferansı'na gidecek İsmet Paşaya verilen talimatın 2. maddesinde Musul vilayetinin gelecckteki statüsü şöyle belirtilmiştir: "...Irak hududu: Süleymanive. Kerkük ve Musul livaları (sancakları) istenecektir. Konferansta bundan farklı olmak üzere tahassül edecek (meydana gelecek, ortaya çıkacak) sekil (durum) için Heyet-i Vekileden (Bakanlar Kurulu'ndan) talimat almacaktır. Şimşir, Atatürk ve Cumhuriyet, s.223; Şimşir, Türk-Irak Iliskilerinde Türkmenler, s.52. 
"Musul vilayetinin, hudud-u millimize (milli sinırlarımıza) dâhil araziden olduğunu biddefeat (birçok defalar) ilan ettik. Lozan'da elyevm (şu anda) karşımızda ahz-ı mevki etmis (yer almıș) olanlar bunu pekâlâ bilirler. Vatanımızın hudutlarını tayin ettiğimiz zaman büyük fedakârlıklara katlandik. Menafiimize mugayir (karșt) olmakla beraber müsalemetperverane (barıs içinde yaşama, iyi geçinme, barıs sever) hareket ettik. Artık milli arazimizden en ufak bir parçasını bizden koparmağa çalışmak pek haksız bir hareket olur. Buna kat'iyen (kesinlikle, asla, hiçbir zaman) muvafakat etmeyiz ( uymaylz)" 133

Mustafa Kemal, 16/17 Ocak 1923'te, İzmit'te Akşam Gazetesi Yazarı Falih Rıfkı Atay'ın sorusu üzerine, Türkiye'nin bütünlüğü için Musul'un mutlaka Misk-1 Milli sınırları içine alınmasının gerektiğine dikkat çekmiştir. ${ }^{134}$ Lozan Konferansı'nın 23 Ocak 1923 tarihindeki oturumunda Musul Meselesi gündeme gelmiştir. Heyet Başkanımız İsmet Paşa, sosyal, siyasi, tarihi, coğrafi, ekonomik ve askerî açılardan İngilizlerin tezinin dayanıksız olduğunu, Lord Curzon ve diğer temsilcilere: “...Musul vilayetinin nüfus çoğunluğunun Türklerle Kürtlerin oluşturduğunu, ikinci olarak, Ingiliz kaynaklarina dayanarak, Kürtlerin Turan kökenli ve Türklerle aynı soydan geldiklerini, üçüncü olarak da Kürtlerin mukadderatlarını Türkiye ile birleștirdiklerini" ifade ediyordu. ${ }^{135}$ Misak-1 Milli sınırları içinde bulunan Türkleri ve Kürtleri bir öz kardeş ve bir millet olarak kabul eden Türkiye'nin, Musul ile ilgili tezi; Kürtlerin Orta Asya'dan ve Türklerle aynı etnik kökenden geldiği temeline dayandırılıyordu. ${ }^{136}$

${ }^{133}$ Atatürk'ün Söylev ve Demeçleri, c. III, s.78.

${ }^{34}$ Mustafa Kemal düşüncesini şöyle ifade etmiștir: “...Musul bizim için çok önemlidir. Birincisi, Musul'da sintrsız servet oluşturan petrol vardır. Ikincisi, onun kadar önemli olan, Kürtlük sorunudur. Ingilizler, orada bir Kürt hükümeti kurmak istivorlar. Bunu yaparlarsa. bu düşünce bizim sımırlarımız içindeki Kürtlere de yayltr. Buna engel olmak için sımır güneyden geçirmek gerekir." Mumcu, Kürt-Islam Ayaklanmast, s.47.

${ }^{135}$ Öke, Musul-Kürdistan Sorumu, ss.192-193.

${ }^{136}$ İsmet Paşa (İnönü) hatıralarında: "Hatta biz Lozan'daki konusmalarımızda, milli davalarımızı biz Türkler ve Kürtler diye bir millet olarak müdafaa ettik ve kabul ettirdik" demektedir. Sabahattin Selek, İsmet İnönü, Hatıralar, c.II. Ankara, Bilgi Yayınevi, 1987. s.202. Türkiye'deki Kürtlerin, Orta Asya'daki Elegeş Nehri yakınında bulunan bir Türk mezarının kitabesinden Oğuzlar'ın bir kolu olduğu gerçeği ortaya çıkmıştır. Kodaman, a.g.c., s. 94: Aydın Taneri, Türkistanlı Bir Türk Boyu Kürtler.Kürtlerin Kökeni, Siyasi, Sosyal ve Kültürel Hayatlart, Ankara,1983, s.7. Çay, a.g.e., s.219, 221; Ali Tayyar Önder, Türkiye'nin Etnik Yapısı, 16.b., Ankara, Fark Yayınları, 2007, s.152, 204. Kürtler hakkında; Irani ( veya Ari), hatta Arabi kökenli olduklarına dair iddialar ileri sürülmüsse de, son yıllarda kaleme alınan gerek etnolojik ve gerek sosyo-kültürel araştırmalar, onların menşei Orta Asya'da bulunan Turani bir kavim oldukları hususunda birleşmektedirler. Bu itibarla dil, edebiyat, dini inançlar, gelenek ve görenek, musiki ve dokumacılıkta Batı (Anadolulular)'yla Doğu Türkleri (Orta Asyalılar) arasında toplum hayatı bakımından herhangi bir farlılaşma göstermeyen Kürtleri, Türk Kültür dairesi içinde telakki etmemiz mümkündür. Mim Kemal Öke, Ingiltere'nin Güneydoğu Anadolu Siyaseti ve Binbaş E.W.C. Noel'in Faaliyetleri, (1919), Ankara, Türk Kültürüüü Araştırma Enstitüsü Yayınları, 1988, s.2. 
İsmet Paşa: “ Musul'un Misak-ı Millî sintrlarl içinde bulunduğunu, nüfusun çoğunluğunu teşkil eden Türk ve Kürtlerin Türk Yönetimi'ne geçmek istediklerini..." belirterek bu bölgenin Türk sınırları içine alınması gerektiğini söylemiş, ayrıca:“ ...Musul ilinin coğrafi, tarihi, siyasi ve ekonomik açılardan Anadolu'nun ayrılmaz bir parçast olduğunu " açıklamıştı. Lord Curzon ise: "Bu topraklar Cemiyet-i Akvam (Milletler Cemiveti) tarafindan Ingiliz mandaterliğine verilmiştir. İlin nüfuz çoğunluğu da Kürt ve Araplardan olusmaktadır. Kürtlerin ise Türklerle bir iliskisi yokıur. Iran kökenlidirler. Bu bölgede yaşayan Hiristiyanlar;Türk Yönetimi'ni istemiyorlar, Kürtler ise kendi kendilerini yönetme özgürlüğ̈̈ istiyorlar" diyerek, Türk tezine karşı çıkmıştı. Aslında, Lord Curzon, zengin petrol yataklarına sahip olan ve İngiltere'nin en önemli sömürgesi konumunda bulunan Hindistan'ı batıdan koruyan bu bölgenin, İngiltere için önemini gizlemeye çalışmıștır. ${ }^{137}$ Lozan Konferansı'nda, sınırlar konusunun en fazla tartışmaya sebep olan kısmı, Türkiye-Irak sınırının belirlenmesi olmuştur. Bu konudaki Türk tezi, Musul vilayetinin Türkiye'nin sınırları içinde olması gerektiği şeklindeydi. Türk Heyeti, bunun haklı gerekçelerini de şöyle sıralıyordu: “Bu vilayette nüfus çoğunluğu Türk ve Kürt'tür. Ingilizler, Mondros Mütarekesi 30 Ekim 1918'de imzalandiktan sonra 3 Kasım 1918'de, mütarekeye aykırl olarak Musul'a girmislerdir." İngiltere Dışişleri Bakanı Lord Curzon. Lozan Barış görüşmelerinin en sert direnişini "Musul Meselesi" görüşülürrken sergilemiş, Fransa ve İtalya temsilcileri de Birinci Dünya Savaşı'nın süper gücü İngiltere'yi desteklemişlerdir. ${ }^{138}$

İngiltere için Irak'ta askeri ve politik istikrarın sağlanması; sadece petrolden beklenen gelir değil, aynı zamanda Basra (İran) Körfezi'nin savunulması, Hindistan, Singapur ve Avustralya ya uzanan deniz yoluna ilaveten yeni havayolunun işletilmesi ve güvenliğinin sağlanması bakımlarından da gerekli hale gelmişti. ${ }^{139}$ Mustafa Kemal, yeni kuracağı Türkiye Cumhuriyeti'nin ekonomik kalkınmasını süratlendirmek amacıyla, zengin petrol yataklarına sahip olan Musul vilayetini (Musul, Erbil, Kerkük ve Süleymaniye) sınırlarımız içine almak istemiştir. İsmet Paşa, Lozan görüşmelerinde, Lord Curzon'a: "Musul'suz Ankara'ya dönmeyeceğini" söylemiş, ${ }^{140}$ Lord Curzon ise: "Bu havalide bulunan 500.000 nüfus tamamen Kürt'tür. Bunlar Türk sayılmaz" derken, İsmet Paşa: "Musul ve çevresi

${ }^{137}$ YÖK, a.g.c., s.178. İsmet Paşa, Musul'un demografik yapısını: Kürtler 263.830, Türkler 146.960, Araplar 43.210, Yezidiler 18.000 ve Gayrimüslim 31.000 olmak üzere toplam 503.000 şeklinde ifade etmiştir. Resmi Türk istatistiklerini kabul etmeyen İngiliz Dıșişleri Bakanı Lord Curzon ise: Musul vilayetinde, 455.000 Kürt, 186.000 Arap, 66.000 Türk, 62.000 Hıristiyan ve 17. 000 Musevi yaşadığını iddia etmiştir. Şimşir, Türk-Irak İliskilerinde Türkmenler, ss.53-54: Öke, Musul-Kürdistan Sorunu , s.267.

${ }_{138}^{138}$ Turan, a.g.e., ss.190-191.

${ }^{139}$ Yergin, a.g.e., s. 230

${ }^{140}$ Mumcu, Kürt-Islam Ayaklanması, s.31; Öke, Musul Kürdistan Sorunu, s.195. 
Türk'tür " iddiasını yenilemiştir. ${ }^{141}$ İngiliz Dışişleri Bakanı Lord Curzon, ABD delegesinin hazır bulunduğu bir gece toplantısında, İsmet Paşayı tehdit ederek şunları söylüyordu:

“Konferansta bir sonuca varacă̆ız, ama memnun ayrlmavacă̆ız. Hiçbir konuda bizi memnun etmiyorsunuz. Hiçbir dediğimizin makul olduğuna, haklı olduğuna bakmaksızın, kabul etmiyor, hepsini reddediyorsunuz. En sonunda su kanlya vardlk ki, neyi reddederseniz hepsini cebimize attyoruz. Ülkeniz haraptır, imar etmeyecek misiniz? Bunun için paraya ihtiyacınız olacaktır. Parayı nereden bulabilecek siniz? Bugün para, dünyada bir bende, bir de yanımdakinde (ABD temsilcisi). Unutmayın, ne reddederseniz hepsi cebimdedir. Ihtiyaç sebebiyle yarın para istemek için karşımıza gelip, diz çöktiü̆ünüz zaman, bugün reddettiklerinizi birer birer çıkarıp size göstereceğiz." ${ }^{4+2}$

İngilizler, Musul vilayetindeki Kürtleri kazanmak amacıyla, Binbaşı Noel'i Kerkük'e, Binbaşı Soon'u Süleymaniye'ye ve Yüzbaşı Hay'ı Erbil bölgesine görevlendirmişlerdi. İngilizler, bölgede etkin olan Şeyh Mahmut'u yanlarına çekemeyince, Musul'a askeri harekât başlatmışlardı. Türkiye, Şeyh Mahmut ile irtibat kurarak, ${ }^{143}$ askeri tedbirler almış, ancak, Lozan Barış görüşmelerini göz önünde bulundurarak, sadece propaganda faaliyetlerini sürdürmüştür. ${ }^{144}$ İtilaf Devletleri, 21 Kasım 1922'de başlayarak, 30 0cak

${ }^{14 i}$ Nurettin Gülmez, Kurtuluş Savașı'nda Anadolu'da Yeni Gün, Ankara, Atatürk Kültür, Dil ve Tarih Yüksek Kurumu, Atatürk Araştırma Merkezi Yayını, 1999, s.69. Lozan Barış Konferansı görüşmelerinde İngiliz temsilcileri tarafından Irak'ta yaşayan Türkler için Ingilizce bir kelime olan "Türcomans" Türkmenler ifadesi kullanılmıs, bu bölgedeki Türkmenlerin Osmanlı Türkleriyle ilișkilerinin olmadığı belirtilmiștir. İngiltere Dișişleri Bakanı Lord Curzon, Irak'ta yaşayan Türkler için: "...Bunlar hiç de Osmanlı Türkleri değillerdir. Bu ülkeye Selcuklu ve Osmanlı istilalartndan çok önce Orta Asya'dan gelmis Turanlı istilacıların ardıllarıdır (birinin ardından gelip, onun orununa -makam, mansip. mesnet, mevki-geçen kimse, halef)" ifadesini kullanarak. Irak'ta yaşayan Türklerin ayrı bir soydan geldiği ve Anadolu Türkleriyle adeta hiçbir ilişkilerinin olmadığını ileri sürmüștür. Hiçbir tarihi dayanağı olmayan Lord Curzon'un bu iddiası, İsmet Paşa tarafindan: "Anadolu Türkleri. Türkmen dive adlandırlan topluluk icinde bulunmaktadur. Musul Türkleriyle Anadolu'da yaşayan Türkler arasında yapılmak istenen ayrım, hiçbir sağlam temele dayanmamaktadır " cevabı verilerek, geçersiz hale getirilmiştir. Seha L., Meray, Lozan Tutanakları, c. I, İstanbul, Yapı Kredi Yayınları, 1993, s.347, 359

${ }^{142}$ Selek, Ismet Inönü, Hattralar, c.II, s.89: Aydemir, Tek Adam. c. II, ss. 113-114

${ }_{143}$ Genelkurmay Başkanı Fevzi Paşa (Mareşal Çakmak) tarafından, Bașbakanlığa yazılan raporda: "Irak'ın kuzevinin bekasının sağlanması için; Seyh Mahmut'un Ingiliz boyunduruğundan kurtarılmast, Irak'ın kuzeyinden TBMM'ye üye seçilmesi. Ingilizlerin Kürtleri aleyhimize kıskırtmak için. vapmakı oldukları propagandaya avm silahla karstlık verilmesi ve özellikle Revandüz harekat esnasinda Ingilizler tarafindan Kürtlere yaptlan mezalim ve facialar hakkında Kürtlerin hafizalarmın canlı tutulmasının sağlanmasını..." vurgulanmıștır. Cumhurbaşkanlığı Arșivi, K.56-1. Dos.65. Fih. 2-5:2-6.

144 Türkiye, Irak'ta propaganda hareketine başlamıs. Diyarbakır'a çok sayıda asker sevk edileceği duyurulmuş, hatta Suruç 'a bir süvari birliği gönderilmiştir. Bu propaganda faaliyetleri, Suriye'de bulunan Fransız Kuvvetlerinin de dikkatini cekmistir. Genelkurmay Baskanı Fevzi Pasa tarafindan Mustafa Kemal Pasaya yazılan raporda: "Divarbakur'daki sahra bataryası Urfa'ya hareket ettirildi. Ingiliz. Sömürge Müsteșari'nın Parlamentoda 
1923'e kadar devam eden görüşmeler esnasında, Milli Mücadele'de kazandığı başarıları hiç dikkate almadan Sevr Antlaşması şartlarını Türkiye'ye kabul ettirmeye çalışmışlar ve Osmanlı Meclis-i Mebusanı tarafından 28 Ocak 1920'de alınan Misak-1 Milli kararlarını kesinlikle kabul etmemişlerdir. Mustafa Kemal, 30 Ocak 1923 'te şu açıklamayı yapmıştır: “Musul vilayeti Türkiye Devleti'nin hududu millisi dâhilindedir; buralarını anavatandan koparı şuna buna hediye etmek hakkl kimseye ait olamaz. Cemiyet-i Akvam (Milletler Cemiyeti)'la da bu meselenin münasebeti (ilgisi) yoktur." 145 İtilaf Devletleri, 31 Ocak 1923'te Türk Heyeti'ne bir barış taslağı vererek, 4 Şubat 1923 'e kadar cevaplandırılmasını istemişler, olumsuz cevap verilince de Lozan görüşmeleri kesilmiştir. ${ }^{146}$

Musul Sorunu, TBMM'de 21 Şubat-6 Mart 1923 tarihleri arasında tartışılmış, TBMM HükümetI'ne ve Lozan Heyeti'ne güven oyu verilmişti. İsmet Paşa, 8 Mart 1923 'te İtilaf Devletleri'ne 31 Ocak 1923 tarihli barış taslağı hakkındaki Türkiye'nin görüşlerini yazılı olarak göndermişti. ${ }^{147}$ Büyük ölçüde Musul Meselesi ve Kapitülasyonlar nedeniyle 4 Şubat 1923’te kesilen Lozan Konferansı, 23 Nisan 1923'te tekrar başlamış, 17 Temmuz 1923 'e kadar süren görüşmeler sonunda, Musul Meselesi hariç diğer sorunlar büyük ölçüde çözümlenmiştir. İsmet Paşa Lozan'da özellikle Musul Meselesi'nden dolayı çok sıkıntılı anlar yaşamış, İngiliz temsilcisi Horace Rumbold'un İstanbul'a bildirdiği gibi, 'örsle çekiç arasında' kalmıştı. ${ }^{148}$ Görüșmelerin uzaması üzerine İsmet Paşa, bu konunun Türkiye ile İngiltere arasında çözümlenmesini önermiş, bu önerisi de taraflarca benimsenmiştir. ${ }^{149}$ İsmet Paşa, 18 Temmuz 1923'te Mustafa Kemal Paşadan Lozan Antlaşması'nı imzalamak için yetki istemiş, Mustafa Kemal Paşa, İsmet Paşaya: "18 Temmuz 1923 günü ıelyazınızı aldım. Hiç kimsede kararsızlı yoktur. Kazandı ̆̆ını başarıyı en sicak ve içten duygularımızla kutlamak için,

'Türklerin yalnız Musul hakkında değil, Suriye hududunda da kuvvetli kutaat toplamakta oldukların işittik' demesi, propagandamızın ciddi olarak etkili olmaya başladığımı göstermektedir" demiştir. Cumhur Başkanlığı Arşivi, K.7/2, Dos.19, Fih. 55.

${ }^{145}$ Atatürk'ün Söylev ve Demeçleri, c. III, s.82; Öke, Musul-Kürdistan Sorunu., s.215.

${ }^{146}$ Atatürk, Nutuk, s.526; Turan, a.g.e., s.191.

${ }^{147}$ İsmet Paşanın 8 Mart 1923 te Itilaf Devletleri temsilcilerine gönderdiği öneriler listesinde Musul Sorunu söyle belirtilmistir: "Türkiye ile Irak arasındaki sınır, isbu antlaşmanın yürïrlüğe girmesinden başlayarak 12 aylik süre içinde Türkiye ile Ingiltere arasında dostça bir çözüm yoluyla saptanacaktır. Antlaşmaya varılamazsa, anlaşmazlık Milletler Cemiyeti (Cemiyet-i Akvam)'ne götürülecektir." Simșir, Türk-Irak Illișkilerinde Türkmenler, s.55.

${ }^{148}$ Kinross, a.g.e., s.434. İsmet Paşa, Ankara'ya dönüşünde, Mustafa Kemal’in Cankaya'da verdiği yemekte Lozan'da yaşadı̆̆ durumu söyle ifade etmistir: "Karşılastığım bütün güçlükleri yalnız siz çözdünüz. Yardımıma koşup beni kurtardınız. Siz olmasaydınız, Lozan'dan cenazem gelirdi benim, cenazem." a.g.e., s.437.

${ }^{49}$ Ömer Kürkçüoğlu, Türk-İngiliz İliskileri, (1919-1926), Ankara Üniversitesi Siyasal Bilgiler fakültesi Yayını, Ankara, 1978, s.287. 
yöntem gereği, antlaşmanın imzalandığını bildirmenizi bekliyoruz kardeșim" telgrafını çekerek gerekli yetkiyi vermiştir. ${ }^{150}$

İsmet Paşa, Mustafa Kemal Paşanın kendisine yetki veren telgrafı üzerine, 24 Temmuz 1923 'de Lozan Antlaşması'nı imzalamıştır. ${ }^{151}$ İsmet Paşa, Mustafa Kemal Paşanın telgrafından çok duygulanmış ve şu cevabı yazmıştı: "Her dar zamanımda, hızır (ölmezlik suyundan içen peygamber) gibi yetişirsin. Dört beş gündür çektiğim ezinci bir düşün. Büyük işler yapmış ve yaptırmış adamsın. Sana bağlılı̆̆ım bir kat daha artmışıtr. Gözlerinden öperim. Pek sevgili kardeşim, sayın önderim.” ${ }^{152}$ Mustafa Kemal Paşa, Lozan Antlaşması'nın imzalandığı gün İsmet Paşaya bir telgraf göndererek, kendisini ve heyet arkadaşlarını şöyle kutlamıştır: "Ulusun ve hükümetin yüksek kişiliğinize vermiş olduğu yeni görevi başarl'yla sonuçlandırdınız. Yurda sıra sıra yararlı işlerle dolu olan ömrünüzü bu kez de tarihsel bir başarlyla yücelttiniz. Uzun savaşmalardan sonra yurdumuzun barışa ve bă̆ımsızlı̆̆a kavuştuğu bu günde, parlak başarılarınız dolayısıyla sizi, sayın arkadașlarımız. Rıza Nur ve Hasan Bevleri ve çalısmalarınızda size yardım eden bütün delegeler kurulu üyelerini içten duygularımla kutlarım"153

Mustafa Kemal ve silah arkadaşları, 30 Ekim 1918'de imzalanan Mondros Mütarekesi ve müteakiben 10 Ağustos 1920'de Osmanlı Devleti'ne zorla kabul ettirilen Sevr Antlaşması şartlarını ortadan kaldırarak, Misak-1 Milli sınırları içinde yeni bir devlet kurmak amacıyla başlattıkları Milli Mücadele'yi hedefine ulaştırarak, itilaf Devletleri'ne Lozan Antlaşması'nı imzalatmayı başarmışlardır. Türkiye Devleti'nin kuruluş belgesi olan Lozan Barış Antlaşması'yla aynı zamanda Avrupa Devletleri'nin Şark Meselesi planını uygulamalarının mümkün olamayacağını kabul etmeleri de sağlanmıştır. Prof. Dr. Hamza Eroğlu'na göre: “ Lozan Barış Konferansı'nda yalnı. Yunanistan'la bir hesaplaşma, harbe son veren bir barış antlaşmast akdi bahis konusu olmamakta, aynı zamanda Birinci Dünya Harbi'nin galipleriyle hesaplașma, hukuki ve siyasi yönden uyuşmazlıklarl çözümleme, yüzyllardan beri sürüklene gelen problemlere hal çaresi aranmakta idi. Açıķ̧a bütün Doğu Meselesi, Konferans'ın ă̆ırlık merkezini teşkil ediyordu... Lozan barışı, İstiklal Savaşı'na son veren ve onu milletlerarası münasebetlerde değerlendiren, gerçekten önemli ve büyük bir eserdir." 154

Musul Meselesi, İngiliz Heyeti'nin olumsuz tutum izlemesi nedeniyle, Lozan Konferansı'nda çözümlenememiş, dokuz ay içinde iki ülke arasında

\footnotetext{
${ }^{150}$ Atatürk, Nutuk, ss. 575-576.

${ }^{151}$ a.g.e., s.576; Harp Akademileri Komutanlı̆̆ı, a.g.e., s.8; Turan, a.g.e., s.192; Eroğlu, a.g.e., s.197; YÖK, a.g.e., s.181; Öke. Musul-Kürdistan Sorunu, s.220; Roux. a.g.e., s.239.

${ }_{152}$ Atatürk, Nutuk, s. 576.

153 a.g.e., s.576; Kinross, a.g.e., s.435

${ }^{154}$ Eroğlu, a.g.e., s.197.
} 
yapılacak anlaşmaya bırakılmıştır. Lozan Barış Antlaşması'nda Irak sınırı şöyle belirtilmiştir : “...Türkiye'yle Irak arasındaki sinır, dokuz ay içerisinde Tïrkiye'yle Ingiltere arasında anlaşma yoluyla saptanacaktır. Belirlenen süre içinde iki hükümet arasında anlaşma olmadı ̆̆ takdirde, anlaşmazlık Milletler Cemiyeti (Cemiyet-i Akvam) Meclisine sunulacaktır. Stnır çizgisi kararlaştırllıncaya kadar Türkiye ve İngiltere Hükümetleri, kesin geleceği bu karara bağlı arazinin şimdiki durumunda herhangi bir değişiklik yaratacak hiçbir askeri ve başka harekette bulunmamayı karşılıklı olarak yükümlenirler."

\section{Türkiye'nin Musul'u İngiltere'nin Mandası Irak'a Bırakmast}

Mustafa Kemal, coğrafi, Ulaştırma ve Muhabere, sosyal, ekonomik, politik, biyografik, askeri, ilmi ve teknolojik özelliklerine ilaveten özellikle tarihi bağları açısından da Musul'u Misak-1 Milli sınırları içine almak istemiştir. Büyük Selçuklu İmparatorluğu'ndan itibaren, Osmanlı İmparatorluğu hâkimiyetine kadar Musul-Kerkük bölgesinde; Irak Selçukluları, Zengiler, Erbil Atabeyliği, Karakoyunlu, Akkoyunlu, Safeviler ve Osmanlı egemenliği olmak üzere, sekiz adet Türk Devleti hüküm sürmüş, bu bölge 800 yıl kadar Türklerin hâkimiyetinde kalmıştır. ${ }^{156}$

Türk-İngiliz ilişkilerinin 1923-1926 yılları arasındaki en önemli parametresini Musul Meselesi oluşturmuştur. Lozan Antlaşması gereğince; Türkiye-Irak sınırını tespit etmek amacıyla Türk ve Ingiliz heyetleri arasındaki görüşmelere 19 Mayıs 1924 'te İstanbul'da başlanmış ve 5 Haziran 1924'e kadar devam etmiştir. Haliç Konferansı adı verilen bu görüșmelerde de tarafların görüşleri değişmemiş, ${ }^{157}$ üstelik İngiliz Heyeti, Nasturi Hıristiyanları nedeniyle Hakkâri'nin de Irak'a katılması gerektiğini savunmuştur. ${ }^{158}$ İki taraf, Lozan'dan sonra 19 Mayıs-5 Haziran 1924 tarihleri arasında yapılan Haliç Konferansı'nda da anlaşamayınca, ${ }^{159}$ İngiltere

${ }^{155}$ Atatürk, Nutuk. s.550; Harp Akademileri Komutanlığı, a.g.e., s.17; Turan, a.g.e., s.193; s.550: YOK, a.g.e., s.181; Şimşir, Türk-Irak Illişkilerinde Türkmenler, ss. 55-56; Eroğlu, a.g.e., s.199; Armaoğlu, a.g.e., s.322.

Başbakanlık Devlet Arşivleri Genel Müdürlüğü, Irak Türkleri Bibliyografyası (A Bibliography of Iraqi Türks), Yayın No: 12, s. XIV

${ }^{137}$ Eski Bahriye Nezareti Binası'nda yapılan Haliç Konferansı'nda Türkiye'yi Fethi Bey (Okyar), İngiltere 'yi Irak'taki İngiliz Yüksek Komiseri Sir Percy Cox temsil etmiştir. Türk Hükümeti'nin Fethi Beye (Okyar) verdiği talimat, Lozan Konferansı'na giderken İsmet Paşaya verilmiş olan hükümet talimatına benzer şekilde düzenlenmişti. Bu talimat da Musul vilayetinin (Süleymaniye, Kerkük ve Musul sancaklarının) Türkiye'de kalacak şekilde sınırın çizilmesi öngörü̈lmüstür. Türkiye'nin bu talebi yerine getirildiği takdirde, bölge petrollerinin işletilmesinde Ingiltere' yle ortaklık kurulabileceği ve öncelik tanınabileceği hususları da yer almıştır. Kürkçüoğlu, a.g.e., s. 290 ,

${ }_{158}$ Ugur Mumcu, Kazım Karabekir Anlattyor, 15.b., İstanbul, Tekin Yayınevi, 1995 s.135; Simşir, Türk-Irak ilişkilerinde Türkmenler, s.57; Kinross, a.g.e., s.470.

Lord Curzon, Lozan görüşmeleri sırasinda, TBMM'de Musul ve Kerkük mebuslarının bulunmamasını, bu bölgenin Misak-ı Milli sınırlarının dışında olduğunun göstergesi olarak savunmuştur. Gerçckte, Musul ve Kerkük mebuslarından Misak-ı Milli'yi 
tarafından Milletler Cemiyeti'ne sevk edilen Musul, 16 Aralık 1925'te İngiltere'nin mandası olan Irak'a bırakılmıştır. ${ }^{160}$

Milletler Cemiyeti kararından biraz önce 1925 yılı içinde Amerikalı bir Jeolog New York'a gönderdiği raporda: "Dünyada hiçbir bölgenin petrol yönünden Irak kadar çok şey ifade etmediğini" bildirmiştir. ${ }^{161}$ Türkiye, Milletler Cemiyeti (Cemiyet-i Akvam)'nin Musul'u Misak-1 Milli sınırları dışında bırakan kararına, tepki olarak, 17 Aralık 1925'te Rusya ile Dostluk ve Tarafsızlık Antlaşması imzalamıştır. ${ }^{162}$ Türkiye'de büyük tepkiyle karşılanan Milletler Cemiyeti'nin kararı, Türk-İngiliz ilişkilerini çok olumsuz şekilde etkilemiş, gerginleşen ilişkiler ve savaş ortamına bağlı olarak, Türkiye askeri hazırlıklara başlamıștır. ${ }^{163}$ Başbakan İsmet Paşa, Kazım Karabekir Paşa ile yaptığı bir görüşme sırasında: "Kazım, Musul boş... Şunu işgal ediversene..." demiştir. Kazım Karabekir Paşa, İsmet Paşaya bir asker olarak bu sorumluluğu almak istemediğini ima eden sözlerle şöyle cevap vermiştir:

"Bu harekât, Ingilizlere karşı ilansız bir harp demek olur. Oradaki kıtalart az da olsa tayyare kuvvetleri üstündür. Kısa bir zamanda takviye edilebilirler. Sevk olunacak kuvvetlerimizin orada dahi muvaffakiyetlerini ümit etmem. Fakat işin tehlikeli ciheti (yönü, tarafl), bu hareketin, Ingilizlerin bütün sahillerimizde faaliyete geçmelerine mucip (neden, gerekçe) olur. İşin daha felaketli ciheti (yönü) de Ermeni ve Yunan ordularlyla yapamadı ğın bu sefer Suriye'den Fransızlarla ve İzmir'den de Italyanlarla yapmaya kalkışmasıdır... Bana geçen gün Mustafa Kemal Paşa da böyle bir teklifte bulunduğu zaman O'na da uzun uzadlya bu mütalaalarımı arz etmiştim. Siz, Hükümet Reisi sıfatıyla, O'nun böyle bir

savunanlar, 16 Mart $1920^{\circ}$ de İstanbul'un işgalinden sonra Malta'ya götürülmüşler, geri kalanlarsa İngilizlerle mücadele etmek amacıyla Irak'a gitmişlerdi. TBMM Başkanı Fethi Bey (Okyar), Heyet Baskanı olarak katıldığı Halic Konferansı'ndan sonra, 6 Ekim 1924'te Dışişleri Bakanlığına gönderdiği telgrafta:" Bağdat'taki Meclis'te Musul mebuslarımın bulunmast, Ingilizlerce Musul'un Bağdat'a irtibatına delil makamında ileri sürü̈lmüs olduğundan, evvelce secilmis olan Musul mebuslarinın TBMM ye kabulü muvafiktur (uygundur) efendim" sözleriyle Musul'un da TBMM'de temsil edilmesinin uygun olacağını ifade etmiștir. Cumhur Başkanlı̆̆ı Arşivi, K. 35/2, Dos. 54. Fih. 70-1.

${ }^{60}$ Armaoğlu, a.g.e., s.322; Turan, a.g.e.s.267. Genis bilgi için bkz, Öke, MusulKürdistan Sorunu, ss.250-290

${ }^{161}$ Yergin, a.g.c., s. 233

${ }^{162}$ Mumcu, Kazım Karabekir Anlattyor, s.136; Armaoğlu, a.g.e., s.323.

${ }_{163}$ Kazım Karabekir Paşa anılarında, Musul'a yapılacak askeri harekâtın komutanlığının, önce Mustafa Kemal, sonra İsmet Paşa tarafından kendisine teklif edildiğini, ancak, bu görevi reddettiğini, Erkan-1 Harbiye-i Umumiye Reisi (Genelkurmay Başkanı) olan arkadaşı Fevzi Paşaya (Mareşal Çakmak): "Musul macerasının Tïrkiye'yi yıkıma götüreceğini" söylediğini ve Fevzi Paşadan su cevabı aldığını ifade etmiștir: "icap ederse yeni bir harbi de göze aldık. Musul bizimdir. Madem ki sulhen (barısla) vermiyorlar, harben (savaşla) almak için Gazi (Mustafa Kemal Paşa) tsrar ediyor. Hükümet de bu fikirde. Bizde. muvaffak olacağımıza süphe yok. İcap ederse Musul değil daha uzaklara da gideriz." Mumcu, Kürt-Islam Ayaklanmast, s.167; Öke, Musul-Kürdistan Sorunu,ss.248-249; Mumcu, Kazım Karabekir Anlattyor, s. 142. 
arzusuna karşı sulh muahedesinin 3. maddesini okuyarak benim serdettiğim (söylediğim) tarzda mütalaa beyan edeceğinize Musul'u işgal etmeye kalkıyorsunuz." 164

Prof. Dr. Halil İnalcık'a göre: “...Musul Meselesi ve Şeyh Sait İsyant dolaytstyla Ingiltere ile genç Türkiye Cumhuriyeti arasında münasebetler çok gergin bir safhada idi." ${ }^{165}$ Cumhurbaşkanı Mustafa Kemal (Atatürk), Başbakan İsmet Paşa (İnönü) ve Genelkurmay Başkanı Fevzi Paşa (Çakmak), Musul'u ele geçirmek amaciyla, kuvvet kullanmaya ve askeri harekâta karar verdikleri sırada, 13 Şubat 1925'te Güneydoğu Anadolu'da başlayan Seyh Sait İsyanı'nın yarattı ğ 1 sorunlar ${ }^{166}$ ve başlatılan inkılâpların yarıda kalmaması için, Türkiye ile İngiltere arasında 5 Haziran 1926'da Ankara Antlaşması imzalanarak, Musul İngiltere'nin mandası olan Irak'a bırakılmıştır. ${ }^{167}$

Ankara antlaşması'na göre: Musul, Irak'a bırakılırken, Musul halkı Irak vatandaşı sayılmış, ancak, 18 yaşını bitirmiş olanlara iki ay içinde isterlerse kendi vatandaşlıklarını seçebilme hakkı tanınmış, Musul bölgesinden elde edilen petrol gelirlerinin \%10'unun 25 yil süreyle Türkiye'ye verilmesi kararlaştırılmıştır. ${ }^{168}$ Şeyh Sait ve Arap İsyanları'nın başlarında şeyhlerin

\footnotetext{
${ }^{164}$ Mumcu, Kazım Karabekir Anlatiyor, ss.137-138.

${ }^{65}$ Halil İnalcık, Atatürk ve Demokratik Türkiye, İstanbul, Kırmızı Yayınları, 2007, s. 112.

${ }^{166}$ Kinross, a.g e., s. 465; Genis bilgi için bkz. Mumcu, Kür-İslam Ayaklanmast, ss. 69103; Eroğlu, a.g.e., ss.287-290; Hasan Rıza Soyak, Atatürk'ten Hattralar, c. I, İstanbul, Yapı ve Kredi Bankası Yayınları, 1973, ss.313-351; Behçet Cemal, Seyh Sait İsyanı, İstanbul, Sel Yayınları, 1955; Öke, Musul-Kürdistan Sorunu ,ss.278-290; Yaşar Kalafat, Sark Meselesi Isı̆ğında Seyh Sait Olayı, Karakteri, Dönemindeki İ c ve Dış Olaylar, Ankara, 1992; Volkan, a.g.e., ss.327-330. İsmet Inönü:" Şeyh Sait İsyani'n bir milli hareket olarak kabul etmemek gerektiğini, şeyhlik menfaatleriyle din konusunda memlekette af̧ılmış olan geniş propagandanın, bunlart tahrik ettiğini " belirtmiştir. Selek, İsmet İönü, Hattralar, c.II, ss. 202-203. Mustafa Kemal'in, Seyh Sait'in, 13 Subat 1925 'te isyan ederek, 12 Nisan 1925 'te yakalanmasından sonra, 1 Ağustos 1925 'te Kuzey Irak'taki Kürt liderlerden Seyit Muhammed Cebbari'ye yazdığı mektup, Musul hakkındaki düşüncelerini sürdürdüğünü göstermektedir:" Muhterem Mücahit Seyit Muhammed ve akrabalarına, memleketin ayrllmaz bir parçası olan Musul'un ahalisinin yakında kurtulacă̆ına inanç ve güven olunarak, öteden beri devam eden çabalarmızda kararlı olmanızı, gelecekteki selamet ve saadetiniz adına yakın gelecekten asla ümit kesmeyerek, zulümlere karș yüksek bir mücadele ruhuyla aydınlık bir istikbal temin edilmesi din kardeşlerimizin huzur ve saadeti için klymettardır. Kurtulus günleri yakındır. Kurtuluş güneşinin doğmasını sabırlı biçimde beklenilmesini hatırlatır. cümlenize muvaffakiyetler (başarılar) temenni eylerim. Cumhurbaşkanlığı Arşivi, K.59-1, Dos.65, Fih.17-18; 17-19

16 Başbakanlık Devlet Arşivleri Genel Müdürlügüu, 111 Numaralı Kerkük Livast Mufassal Tahrir Defteri, Yayın No:64, s.3; Başbakanlık Devlet Arşivleri Genel Müdürlügüu, Musul-Kerkük ile İlgili Arşiv Belgeleri, Yayı No:11, s.46; Üçok, a.g.e. ,s. 355; Kinross, a.g.e., s.478; Armaoğlu, a.g.e.,ss.322-323; Volkan, a.g.e.,s.328; Başbakanlık Devlet Arşivleri Genel Müdürlü̈ü, Irak Türkleri Bibliyografyası (A Bibliography of Iraqi Türks), Yayın No:12, s.XVI; Mumcu, Kazım Karabekir Anlattyor, s.136. Geniş bilgi için bkz. Öke, MusulKürdistan Sorunu, ss.290-319.

${ }^{168}$ Türkiye daha sonra, 500.000 İngiliz Sterlini karşılığında, Musul petrol gelirinin $\% 10$ 'unun 25 yıl süreyle alınması hakkından vazgeçmiştir. Başbakanlık Devlet Arşivleri
} 
bulunmaları, bölücü ve irtica amaçlı olmaları ortak noktalarını teşkil etmektedir. Musul Meselesi'nin Türkiye aleyhine çözümlenmesi nedeniyle, Türk-İngiliz ilişkileri bir müddet durgunluk yaşamıştır. ${ }^{169}$ Türkiye'nin, 5 Haziran 1926'da İngiltere ile Ankara Antlaşması'nı imzalayarak, Musul'un İngiltere'nin mandası olan Irak'a ait olduğunu kabul etmesinin sebepleri şunlardır:

1) Mudanya Mütarekesi'nden 10 ay kadar sonra ancak 24 Temmuz 1923'te imzalanan Lozan Antlaşması'nda, Musul Meselesi'nin çözümlenememesi ve dokuz ay içinde İngiltere ile Türkiye arasında yapılacak görüşmelere bırakılması.

2) Musul Sorunu'nu çözümlemek amacıyla, 19 Mayıs 1924'te başlayan ve 5 Haziran 1924'te sona eren İstanbul/Haliç Konferansı'nda İngilizlerin Hakkâri bölgesini de istemeleri ve görüşmelerden olumlu bir sonuç alınamaması.

3) İngiltere'nin Musul Meselesi'ni 6 Ağustos 1924'te Milletler Cemiyeti (Cemiyet-i Akvam)'ne götürmesi, bir gün sonra 7 Ağustos 1924'te Nasturilerin Hakkâri bölgesinde isyan etmeleri, Ağustos ayı sonunda isyanın bastırılması. ${ }^{170}$

4) 1.Ordu Komutanı Kazım Karabakir Paşanın 26 Ekim 1924 ve 2.Ordu komutanı Ali Fuat Paşanın 30 Ekim 1924'te askerlikten istifa ederek, milletvekilliği görevine başlamak istemeleri. ${ }^{171}$

Genel Müdürlüğ̈̈, Musul-Kerkük ile İlgili Arșiv Belgeleri, Yayın No:11, s.51; Hacettepe Üniversitesi, a.g.e., s.275; Turan, a.g.e., s.268. Musul vilayeti (Musul, Erbil, Süleymaniye ve Kerkük) Türkleri istedikleri taktirde Türkiye Cumhuriyeti vatandaşlığını seçebilme hakkına sahip olmuşlardı. Simşir, Türk-Irak Illiskilerinde Türkmenler, ss.67-68. Ankara Antlaşması'nın, günümüzde Türkiye ile Irak arasında yaşanan ve ülkemizin bekasını tehdit eden bazı olaylara ışık tutacă̆ı değerlendirilen önemli maddeleri şunlardır:

"I. Türkive ile Irak arasındaki hudut, Cemiyet-i Akvam'm 29 Ekim 1924 tarihli toplantısında kararlaştırıldı ğı şekilde (Bürüksel Sınır Çizgisi) kesinleşmiştir..."

"6. Taraflar, bir veya birkaç silahlı kişinin sınır mıntıkasında yağmactlı veya eşkyalık yapmak maksadıyla, girisecekleri hazırlıklara, sahip olduklarl bütün vasıtalarla karşı koymaya ve bunların sinurdan geçmelerine mani olmayl karşılıkl olarak taahhüt ederler."

"7. 11.maddede zikredilen yetkili memurlar, sınır mintıkasında yağmacılık veya eşkıyalık yapmak için bir veya birkac silahlı kişinin hazırlıklarda bulundukların haber aldiklarında ihmal etmeden birbirlerini haberdar edeceklerdir..."

"9. Silahlı bir veya birkac kiși sınır mintıkasında bir cinayet veya bir cürüm işledikten sonra, diğer sınır mıntıkasına iltica ederse oranın, bu kişileri silahları ve yağma ettikleri esva ile birlikte, иуruğu bulunduğu tarafa teslim etmesi mecburidir...” Başbakanlık Devlet Arşivleri Genel Müdürlügü, Musul Kerkük ile İlgili Arșiv Belgeleri, Yayın No:11, ss .47-51.

${ }^{169}$ Armaoğlu, a.g.e., s.323; Turan, a.g.e., s.268.

170 Genelkurmay Başkanı Fevzi Paşa, Diyarbakır'daki Kolordu Komutanı Cafer Tayyar Paşaya çektiği telgrafta: "Ícap ederse esklyayı Londra'ya kadar takip edeceğiz" demiștir. Mumcu, Kazım Karabekir Anlatiyor, ss.142-143.

${ }^{171}$ a.g.e., 146-147. Mustafa Kemal, bu istifaları bir komplo olarak şöyle değerlendirmiștir: "Baylar bir komplo karsıısında bulunduğumuz yargısına varmakta hic duraksamadım... Hakkâri bölgesinde Nasturi ayaklanmasını bastırmaya çalıștı ğımız bì sırada, Ingiltere Hükümeti de Hükümetimize kesin süreli bir nota verdi. Meclisi olağanüstü 
5) Nakşibendî Tarikatı'na mensup Şeyh Sait'in, 13 Şubat 1925 'te Genç iline bağlı Piran'da isyan başlatması, isyanın kısa sürede Güneydoğu Anadolu'ya yayılarak, Anadolu'nun bütünlüğ̈unü tehdit edecek boyutlara ulaşması, isyanın ancak ülke genelinde seferberlik ilanından ve Mustafa Kemal'in halkı Cumhuriyeti korumaya davet etmesinden sonra 12 Nisan 1925 'te bastırılması. ${ }^{172}$

6) Nasturi ve Şeyh Sait isyanlarının etkisiz hale getirilmesi sırasında, Türk Silahlı Kuvvetleri'nin muharebe gücü etkinliğinin çok zayıflamış ve ekonomik yük getirmiş olması.

7) Bakanlar Kurulu tarafından, 8 Aralık 1924'te kurulan Terakkiperver Cumhuriyet Fırkası'nın çeşitli olaylara karıştığı gerekçesiyle 3 Haziran 1925 'te kapatilması.

8) Türkiye'nin henüz üye olmadığı, Milletler Cemiyeti (Cemiyet-i Akvam)'nin, İngiltere'nin etkisiyle 16 Aralık 1925 'te, Musul'u bu ülkenin mandası altında bulunan Irak'ın sınırları içine dâhil edilmesi kararını alması.

9) Türkiye'nin, Milletler Cemiyeti'ne üye olabilmek için, o günün koşullarında dünyanın süper gücü rolünü oynayan İngiltere'nin politik desteğine ihtiyaç duyması.

10) Terakkiperver Cumhuriyet Fırkası'nın Başkanı Kazım Paşa (Karabekir), Başkan Vekili Rauf Bey (Orabay) ve Genel Sekreteri Ali Fuat Paşa (Cebesoy) ile Mustafa Kemal Paşa (Atatürk), İsmet Paşa (İnönü) ve Fevzi Paşanın (Çakmak) yollarının ayrılması.

11) Yunanistan ile Türkiye arasında, İstanbul'daki Rumlar ve Batı Trakya'daki Türkler hariç Türkiye'de yaşayan Rumların ve Yunanistan'da yaşayan Türklerin değiştirilmesi esnasında (Etabli Meselesi) problemler çıkması, Türkiye'nin Rum Ortodoks Patriği'ni sınır dışı etmesi ve iki ülke ilişkilerinin gerginleşerek tekrar savaş durumuna gelmesi.

12) Trablusgarp Savaşı'ndan itibaren, Ege Denizi'ndeki 12 Adaları elinde bulunduran İtalya'nın, eski Roma İmparatorluğu'nu yeniden

olarak toplantıya çă̆ırdım. Ingiltere'nin kesin süreli notasına bildiğiniz biçimde cevap verdik. Savaşı bile göze aldık. Isste, söz konusu ettiğimiz kişiler, bu çetin günlerde, bir yabanct devletin bize saldırabileceği günlerde, kendilerinin de bize saldtrarak, ereklerine (amaçlarına) kolaylıkla ulaşabilecekleri kuruntusuna kapıldılar. Savaşa hazır bir durumda bulundurmaya zorunlu oldukları ordularını bassız bırakıp, daha önce sevmediklerini söyledikleri siyasa alanına kostular..." Atatürk, Nutuk, ss.622-625; Kinross, a.g.e., s.461; YOK, a.g.e., ss. 30-31. Kazım Karabekir Paşa da anılarında, ordudan çekilme kararını "Ingilizlere karşı Musul nedeniyle açılacak savaşa" bağlamıștır. Mumcu, Kazım Karabekir Anlatlyor, s.149.

${ }^{172}$ Lewis, Modern Türkiye'nin Doğuşu, s.275; Hacette Üniversitesi, a.g.e.s.s.275. 
canlandırma politikası takip etmeye ve Türkiye üzerindeki emellerini açıkça gündeme getirmeye başlamas1. ${ }^{173}$

13) Türkiye'nin Lozan Barış Antlaşmasıı'nda uluslar arası bir komisyonun yönetimine bırakılan Çanakkale ve İstanbul Boğazları'nı tekrar egemenliği altına almak istemesi. ${ }^{174}$

14) Suriye ve Lübnan'1 mandası altına alan Fransa ile Lozan Antlaşması'nın ardından, Osmanlı borçlar meselesinin, Türkiye-Suriye sınırının tespiti konusunun (Hatay Meselesi), Türkiye'deki Fransız misyoner okullarının statüsünün çözümlenememiş olması, iki ülke arasındaki ilişkilerin gerginleşmesi.

15) Türkiye'nin, Rusya ile iyi ilişkiler geliştirmesine rağmen, 12 Mart 1917'de Çarlık rejimini yıkarak iktidarı ele geçiren Bolşevik rejimini (komünizm) tehdit olarak algılamaya başlaması.

16) 4 Haziran 1878 'den itibaren Kıbrıs'1, 15 Kasım 1918'den sonra Irak'ı egemenliğinde bulunduran İngiltere'nin ve Suriye'yi mandasına alan Fransa'nın güneyden, Trablusgarp Savaşı'nda 12 Adaları alan İtalya'nın batıdan Türkiye'yi tehdit etmeleri.

17) Mustafa Kemal Paşanın, Trablusgarp Savaşı'ndan itibaren, Milli Mücadele'nin sonuna kadar (1911-1923) 12 yıl süren fiili savaș, 1923-1926 yılları arasında üç yıll süren dolaylı savaş haline son vererek: "Yurtta sulh, cihanda sulh" politikasını uygulama alanına koymak istemesi, Balkan Antantı ve Sadabat Paktı'nın önkoşullarını hazırlaması. ${ }^{175}$

${ }_{174}^{173}$ Şimşir, Türk-Irak İlişkilerinde Türkmenler, ss .66-67.

174 Armaoğlu, a.g.e., s.343.

${ }^{175}$ Mustafa Kemal bir Macar diplomatına: “... Evet, efendim, ben de Makedonyaltyım. Ama hiçbir toprak isteğinde bulunmuyorum” demiştir. Ayrıca Dışişleri Bakanı Türkiye'nin dış siyasetini şöyle tanımlamıștır: "Türkive'nin başkasının bir karıs toprağında gözü yoktur. ama kendi toprağından da bir karışıı feda edemez." Kinross, a.g.e., s.528. Orta Doğu, Osmanlı egemenliği sona erdikten, özellikle Musul Misak-ı Milli sınırları dıșında kaldıktan sonra, bağımsızlık ve çıkar çatıșmalarının yaşandığı dünyanın en sorunlu bölgesi haline gelmiştir. Bernard Lewis Osmanlı'dan sonra Mustafa Kemal'in 'Yurtta barıș, dünyada barıș' düşüncesinin Orta Doğu için önemini ve endişelerini şöyle ifade etmiştir: "Osmanlt Imparatorluğu, Orta Doğu'ya bir yapı ve koruyucu bir perde sağlamıs. onu dısarıdan gelen birçok tehlikeye karşı korumuştu. Şimdi bunlar ortadan kalkmış bulunuyordu. Osmanlı yapıst ve sistemi yerine sonuçta hepsi bozulup dağılan yenileri getirilmisti. Artık koruyucu perde eksikliği yoktu, ama korumada Avrupalı devletler tarafindan ancak birbirleri için sağlantyordu. Bu nedenle de Orta Doğu ülkelerinin halklarının çoğunluğu içıin pek fazla yararlı de ğildi. Bir yanda İngiliz ve Fransızlar ve öteki yanda Orta Doğu halkları için bu dönemin bilânçosu ne olmuştu? Orta Doğu'da Ingiliz ve Fransız güçlerinin bulunduğu dönem, modern tarihin en büyük zaferlerinden birinin hemen ardindan son bulmasina kadar ne basarmıștı? Sonuçların Batılı devletler ya da Orta Doğu'yla halklarl için herhangi bir değeri var mıydı?" Lewis, Orıa Doğu, Hıristiyanlığın Doğuşundan Günümüze Orta Doğu'nun 2000 Ylllk Tarihi, s.277. 
18) Mustafa Kemal Paşanın, Türkiye'yi çağdaş uygarlık düzeyinin üzerine çıkartmak amacıyla, başlattığı inkılâplara devam etmek istemesi.

19) Mustafa Kemal Paşanın, Türkiye'yi tarım ülkesi koşullarından süratle sanayi ülkesi konumuna getirmek amacıyla. Sanayi İnkılâbı'nı gerçekleştirmiş olan İngiltere'yi bu konuda bir model olarak görmesi.

20) Türkiye'nin yeniden inşası, tarım, sanayi ve hizmetler sektörlerinin geliştirilmesi için, İngiltere'nin sermayesinden istifade edilmesinin düşünülmesi.

21) Rusya hariç, diğer sanayi ülkeleriyle yeterli seviyede ilişki kuramayan Türkiye'nin, Birinci Dünya Savaşı'ndan sonra, dünyanın süper gücü olan İngiltere'nin, tecrit politikasından kurtarılarak, ulaştırma ve muhabere, sosyal, politik, ekonomik, askeri, ilmi ve teknolojik milli güç unsurlarını geliştirme projesi.

22) Bir Alman bilim adamı tarafindan 1871'de Musul'da petrol olduğunun keşfedilmesine, Amerikalı bir jeolog tarafından 1925'te aynı bölgede çok zengin petrol yataklarının olduğu rapor edilmesine rağmen, henüz petrol çıkarılmaya başlanmaması. ${ }^{17 t}$

23) Nasturi ve Şey Sait İsyanları'ndan sonra, Reçkotan , Raman, Pervari, Sason, 16 Mayıs-17 Haziran 1926'da 1.Ağrı isyanlarının çıkması ve Ağrı İsyanı'nın halen devam etmesi. ${ }^{177}$

24) Mustafa Kemal Paşanın Ankara Antlaşması'nı kabul etmesinde; Türkiye'nin kısa vadede bölgesinde (Balkanlar, Kafkaslar ve Orta Dogu), orta vadede dünyada etkili bir devlet haline getirilerek, Lozan'da çözümlenemeyen sorunlar için, uygun koşulların oluşturulması, uzun vadede İngiltere'nin de desteğini almak suretiyle Misak-1 Milli'nin tam olarak gerçekleştirilmesinin sağlanması düşüncesinin olduğu anlaşılmaktadır. Türkiye'nin, 1936'da Boğazlar, 1938-1939 yıllarında Hatay Sorunlarını İngiltere'nin desteği ile çözebilmesi, bu düşünceleri teyit eden emarelerdir.

\section{SONUÇ}

Mustafa Kemal'in, Musul'u Misak-1 Milli sınırları içinde göstermesinin ve Musul Meselesi ile çok yakından ilgilenmesinin amacı: iç ve dış bölücü unsurları ortadan kaldırmak, Irak'ın Kuzeyindeki Türkmenler ve Kürtleri Anadolu'daki soydaşlarının coğrafi, sosyal, ekonomik, politik, askeri, biyografik, ilmi ve teknolojik milli güç unsurlarıyla kültür temeline dayalı

${ }^{176}$ Musul'un Kerkük sancağına altı mil mesafede bulunan Baba Gurgur bölgesinde 15 Ekim 1927 günü sabah saat 03.00'de 1500 feet derinliğinde açılan 1 No.lu kuyudan kükremcyi andıran ve çölü baştanbaşa saran korkunç bir gürültüyle ilk petrol çıkartılmıştır. Yergin, a.g.e., s.234.

Mumcu, Kürt-İslam Ayaklanmast, ss.171-172. 
olarak, Türk üst kimliği ${ }^{178}$ altında Misak-1 Milli sınırları içinde birleştirerek, Türkiye'nin, ${ }^{179}$ önce bölgesel sonra dünya gücü (küresel güç) haline gelmesini ve çağdaş uygarlık düzeyinin üzerine çıkmasını sağlamaktı. Mustafa Kemal, savaşların yaralarını sarmak, yıkıntılarını onarmak, ekonomik kalkınmayı gerçekleștirmek ve çağdaşlaşmaya yönelmek istiyordu. Birinci Dünya Savaşı'ndan galip olarak çıkan, o günün koşullarında süper devlet konumunda bulunan, Milletler Cemiyeti'nde her istediği kararı aldırabilen Büyük Britanya İmparatorluğu ile yeni bir çatışmaya girmenin, yukarıda sayılan nedenler de dikkate alındığında oldukça büyük riskler taşıdığının farkına varmıştır. Mustafa Kemal, her zaman olduğu gibi, durması gerektiği sınırı bilerek, ${ }^{180} \mathrm{o}$ günün koşullarında en doğru hareket tarzını seçmiştir. ${ }^{181}$ Türk-İngiliz ilişkileri; Birinci Dünya

${ }^{178}$ Bernard Lewis'e göre: “....Halk bir zamanlar kendisini Türk diye adlandırmıst ve konuştukları dile yine Türkçe deniyordu. Fakat Osmanlıların Imparatorluk toplumunda etmik bir terim olarak Türk deyimi az kullanılmıştı ve özellikle Türkmen göçebelerini veya daha sonra Anadolu köylerinin Türkce konusan cahil ve kaba köylülerini ifade etmek üzere daha çok kü̧̧ültücü anlamda idi. Bunu, Istanbullu bir Osmanlı efendisi için kullanmak bir hakaret olurdu." Lewis, Modern Türkiye'nin Doğuşu, s.1.

"Türkce konusan Anadolu'ya Türkive ad, vaklasık olarak 11 yüzyzlda. Türkler tarafindan ilk fethinden beri Avrupalılarca verilmiștir. (Türkler tarafindan fethedilen Anadolu toprakları hakkında Türkiye adl ilk kez 1190 tarihli Barbarossa Haçlt Seferinin vekayetnamesinde gözükür. 13. yüzvilda bu deyim Battl yazarlar arasinda artık yaygın bir sekilde kullanilmaktadır.) Fakai Türkler kendileri 1923'e kadar bunu ülkelerinin resmi adt olarak benimsemediler. Benimsediklerinde de. Avrupalı menşeini açıkła belli eden bir sekli (Türkiye) kullandılar..." Lewis, Modern Türkiye'nin Doğuš, s.1; Prof.Dr. Halil İnalcık'a göre: “...Avrupa nazarında, Osmanlı İmparatorluğu, bir Türk Imparatorluğu idi. Osmanlılık. Türklïkle bir tutulmakta ve Türkler, milletleri boyunduruk altında tutmaya çalışan bir millet olarak dünyaya ilan edilmekte idi." İnalcık, a.g.e., s.141.

${ }^{180}$ Prof. Dr. Vamık D.Volkan ve Prof. Dr. Norman Itzkowitz, “Ölümsüz Atatürk" adlı eserde, Mustafa Kemal Paşanın kişilik yapısını analiz etmişler ve su değerlendirmeyi yapmıșlardır: "Mustafa Kemal' in kisilik yapısı, kendisinden seçkin bir insan olmasın talep ediyordu; Mustafa Kemal'in üstünlüğü,maddi dünyanın koşulların gerçekçi bir gözle değerlendirerek söz konusu talebi gerceklesebilir hale getirme yeteneğinde yatar. Mustafa Kemal, gerçeklik ilkesinin sintrlarım test etmesini ve kendisine zarar getirmesi muhtemel diurtüsel eylemlerden kaçınmasın biliyordu. Sezgilere dayanarak harekete geçmek onun için kabul edilebilir bir seydi-ama dürtüsel olarak eyleme yönelmek değil. Sezgileri ya da kendi kişilik yapısının talepleri gerçeklik ilkesinin sınırlarını aşı̆̆ğ zaman (ki liderlik iddiasında bulunduğu kimi durumlarda bu yaşanmışt ), yeni bir manevrayla nesnel dïnyanın sinırlarımı kendi ihtiyaçların karșlamaya yetecek ölçüde genisletmesini bilivordu. O'nu gerçek bir lider haline getiren şey, O'nun koşullara uyarlanma konusundaki sira dış yeteneğiydi. Kazım Karabekir, Ali Fuat ya da diğer önemli kisiler Mustafa Kemal gibi hareket etmeve asla cesaret edemezlerdi; böyle bir cesareti göstermis olsalar dahi, zorunlu esneklikten yoksunlardt." Volkan, a.g.e., s.214.

${ }_{181}$ Ingiltere ile 5 Haziran 1926'da imzalanan Ankara Antlaşması, 7 Haziran 1926'da Türkiye Büyük Millet Meclisi gündemine getirilmiş, yapılan görüşme ve tartışmalardan sonra, Dışişleri Bakanı Dr. Tevfik Rüştï Bey (Aras), söz almış ve düşüncelerini: “...Yakındoğu'da baslıca gücü temsil eden Türkive Cumhuriveti'nin en önemli siyaseti, medeni milletler arasında intizam ve terakki unsuru olarak çalısmak olduð̆undan, cihanın ve Yakındoğu'nun barıs ve huzuru ve Irak' in istiklal ve saadeti namma ve Büyük Britanya İmparatorluğu ile iliskilerimizi normal bir hale getirmek icin tek askıda kalan bu arazi meselesinden fedakarlıklara katlandık. Memleket nazik bir durumdadır. Dokuz yıldır (1914-1923 yıllart arası kast edilmiştir) savaşılan bir durumdan çıkıyoruz. Musul hakkındaki kararı tanımamak, 
Savaşı'nda Irak Cephesi'nin devamı olarak,1919-1923 yılları arasında savaş, 1923-1926 yılları arasında dolaylı savaş ve 1926-1938 yılları arasındaysa barışın kurulması dönemlerini yaşamıştır. ${ }^{182}$ Başkan Carter, Amerika Birleşik Devletleri (ABD), 1940'1ı yıllarda İngiltere'nin global (dünya çapında, küresel) sorumluluklarını aldıktan sonra, Orta Doğu'daki rolünün dikkate alınması için, ${ }^{183}$ İngiliz Dışişleri Bakanı Lord Lansdowne'in 1903'de İngiltere Parlamentosu'nda yaptığı konuşmayı, Rusya'nın Afganistan'ı işgali üzerine Ocak 1980'de Senato'da şöyle tekrar etmiştir: "Bir dış güç tarafindan, Basra Körfezi'nde kontrolü ele geçirmek için yapllacak teşebbüs, $A B D$ 'nin hayati menfaatlerine bir tecavüz olarak kabul edilecektir. Askeri güç dâhil, eldeki her imkânla geri püskürtülecektir." 184

ABD ve İngiltere Koalisyon Kuvvetleri, 20 Mart 2003'te İkinci Körfez Harekatı'nı icra ederek, Irak' 1 işgal etmelerinden sonra hazırlanan 8 Mart 2004 tarihli "Irak Devleti'nin Geçiş Süreci İçin Yönetim Hukuku”nda, Osmanlı'nın Musul vilayeti, "Kürdistan Bölge Yönetimi” olarak adlandırılmış, Dohuk, Erbil, Süleymaniye, Kerkük, Diyala, ve Neneveh bölgelerini kapsamıştır. Kerkük'ün statüsü yapılacak halk oylaması sonucu belirlenecektir. Kerkük'ün, Irak'ın kuzeyindeki Kürdistan Bölge Yönetimi'nin sorumluluk bölgesine verilmeyerek, özel statüde merkezi yönetime ve tüm Irak halkına ait olması; Türkiye'nin Kerkük-Yumurtalık Petrol Boru Hattı'nı işleterek uygun koşullarda petrol temin etmesi, Türkmenlerin güvenle yaşamlarını sürdürebilmeleri ve Irak'ın toprak bütünlüğünün sağlanması açılarından, kırmızıçizgi olarak kabul edilmelidir. Adı geçen yasada: "Kürdistan Bölge Yönetimi terimi, Kürdistan Ulusal Meclisi'ni, Kürdistan Bakanlar Kurulu'nu ve Kürdistan bölgesindeki bölge yargl idaresini belirtir" denilmiştir. ${ }^{185}$ Bugün, Irak'ın kuzeyinde, bankası, para birimi, üniversitesi, bayrağı, pulu, yasama, yürütme ve yargı sistemi olan ilan edilmemiş bir devlet yönetimi oluşturulmuştur. Irak'ın kuzeyindeki bu yapının, gelecekte Türkiye'nin bütünlüğüne tehdit teşkil edeceği anlaşılmaktadır.

Irak nüfusunun; yaklaşık \%65'ini Araplar, \%18'ini Kürtler, \%12'sini Türkmenler, \%3'ünü Asurîler/ Süryaniler, \%2'sini ise diğer gruplar (Yahudi,

bizi ister istemez yeni bir savaşa sürükleyecekti. Faşist Italya aleyhimize yürümeye haztrdı. Gazi Atatürk ve Hükïmeti bunu cok ivi bilivordu. Bunun içindir ki, bağrımıza tas basarak. Musul'u burakmaya razı olduk" şeklinde ifade etmiştir. Öke, Musul-Kürdistan Sorunu, s.308

${ }^{182}$ Turan, a.g.e., s. 266

${ }^{183}$ Kennedy, a.g.e., s. 630 .

${ }^{184}$ Ingiltere Dıșişleri Bakanı Lord Lansdowne, Rusya ve Almanya'yı, İran (Basra) Köfezi'nden çekilmeleri için uyarmıştı. İngiltere Dışişleri Bakanı Lord Lansdowne'nin Osmanlı Devleti Bağdat Demiryolu Hattı'nın yapım yetkisini 1903 'te Almanya'ya verdiği zaman, İngiltere adına söylediği sözleri, Başkan Carter, Rusya Afganistan'ı işgal ettiği zaman Amerika Birleşik Devletleri (ABD) adına aynen tekrar etmiştir. Yergin, a.g.c., s.805; Winstone, a.g.e., s.484.

${ }^{185}$ Irak Devleti'nin Geçiş Süreci İ̧̧in Yönetim Hukuku, 8 Mart 2004, madde:53.A. 
Yezidi) oluşturmaktadır. Nüfusun, \%97'si Müslüman, \%3'ü Hıristiyan olup, Müslüman nüfusun \%55'i Şii (Araplar, Türkmenler), \%45'i Sünni (Araplar, Kürtler, Türkmenler) mezhebine mensup bulunmaktadır. Devletin resmi dini İslam, resmi dili ise Arapça ve Kürtçe kabul edilmiştir. 1932 yıllnnda bağımsızlığını kazanan Irak'ta Türkmenler, kurucu unsur, Türkçe resmi dil kabul edilmişken, yeni anayasada Türkmenler adeta yok sayılmıştır. Irak'ın sosyal yapısının oldukça karmaşık bir durum gösterdiği görülmektedir. Irak. halen, 115 milyar varil teyitli, 215 milyar varil tahmini petrol rezervleriyle dünya petrol rezervinin \%11'ine sahip olup, Suudi Arabistan'dan sonra dünyada ikinci sırada bulunmaktadır. Irak, 3.12 trilyon metreküp teyitli doğalgaz rezervine ve Orta Doğu'daki diğer ülkelere göre yeterli su kaynaklarına sahip nadir ülkelerden birisidir. Yeraltı ve yer üstü kaynakları, Irak'ı çekim merkezi haline getirmekte, sosyal yapısının zayıflığı istismara müsait firsatlar yaratmakta, bu durum, geçmişte olduğu gibi bugün de Türkiye'yi coğrafi, sosyal, ekonomik, politik ve askeri konularda çok olumsuz şekilde etkilemektedir.

Musul Meselesi, Ankara Antlaşması'ndan sonra da Türkiye'nin dış politikasının en önemli parametresi olmuştur. İkinci Körfez Harekâtı'ndan sonra, Irak'ın kuzeyindeki Kürt gruplarının kısa vadede federasyon, orta vadede bağımsızlık ve uzun vadede de "Büyük Kürdistan"ı gerçekleştirme faaliyetleri yoğunluk kazanmıştır. Bu gelişmelerin, ülkemize etkileri dikkate alındığında, Mustafa Kemal'in, Musul'u fiilen Misak-ı Milli sınırları içine alma çabalarında ne kadar haklı olduğu, 80 yıl öncesinden ufkun ötesindeki tehdidi gördüğü bugün daha net olarak anlaşılmaktadır. Petrol stratejik hammadde niteliğini koruduğu sürece, gerek Irak içindeki etnik grupların, gerekse bölgesel ve uluslar arası güçlerin, Irak petrol rezervlerinin büyük bir kısmını kapsayan eski Musul vilayetine bağlı Kerkük vilayeti üzerindeki çıkar çatışmalarının, uzun vadede de devam edeceği görülmektedir.

\section{KAYNAKÇA}

\section{Arşiv Belgeleri}

Ankara Üniversitesi Türk Inkllâp Tarihi Enstitüsü Arşivi

Başbakanlık Arşivi

Cumhurbaşkanlığı Arşivi

Genelkurmay ATASE Başkanlığı Arşivi 


\section{Kitap ve Makaleler}

Akşin, Sina, İstanbul Hükümetleri ve Millî Mücadele, c.I, Mutlakıyete Dönüş, 19181919, İstanbul, Türkiye İş Bankası Kültür Yayınları, 1998.

Arı, Kemal, Birinci Dünya Savaşı Kronolojisi, Ankara, Gnkur. Basımevi, 1997.

Armaoğlu, Fahir, 20. Yüzyıl Siyasi Tarihi, 2 Cilt, 1914-1995, 12.b., İstanbul, Alkım Yayınevi, 2000.

Atatürk, Nutuk, Ankara, Türk Dil Kurumu Yayınları, Gnkur. Basımevi, 1981.

Atatürk'ün Tamim, Telgraf ve Beyannameleri (ATTB), 4 Cilt, Ankara, Ankara Üniversitesi Türk İnkılâp Tarihi Enstitüsü Yayınları, 1991.

Atatürk'ün Söylev ve Demeçleri, 3 cilt, 5.b., Ankara, Anara Üniversitesi Türk İnkılap Tarihi Enstitüsü Yayınları, Türk Tarih Kurumu (TTK) Basımevi, 1997.

Atay, Falih Rıfkı, Mustafa Kemal'in Mütareke Defteri, İstanbul, Sel Yayınları, 1955 .

Falih Rıfkı ve Mahmut Soydan, Atatürk'ün Anıları, 1917-1919, Ankara, Olgaç Matbaası, 1982.

Aydemir, Şefket Süreyya, Makedonya'dan Ortaasya'ya Enver Paşa, c.III, 1911922, İstanbul, Remzi Kitabevi, 1993.

Şevket Süreyya, Tek Adam, c. I, III, 22.b., İstanbul, Remzi Kitabevi, 2004.

Başbakanlık Devlet Arşivleri Genel Müdürlüğü, Musul-Kerkük ile Illgili Arşiv Belgeleri, 1525-1919, Yayin No: 11, Ankara, 1993.

Irak Türkleri Bibliyografyası (A Bibliography of Iraqi Türks), Yayın No:12, 1994.

111 Numaralı Kerkük Livası Mufassal Tahrir Defteri, Yayın No:64, Ankara, 2003.

Belen, Fahri, Birinci Cihan Harbi'nde Türk Harbi, c.V, 1918 Yılt Hareketleri, Ankara, Gnkur. Basımevi, 1983.

Cemal, Behçet, Şeyh Sait İsyanı, İstanbul, Sel Yayınları, 1955.

Criss, Bilge, İsgal Altında İstanbul, 6.b., İstanbul, İletişim Yayınları, 2007, s.87.

Çay, A. Haluk, Her Yönüyle Kürt Dosyası, 4.b., Ankara, T. Ofset Matbaacılık, 1996.

Çetiner, Yılmaz, Son Padişah Vahdettin, 2.b., İstanbul, Milliyet Yayınları, 1993.

Ekinci, Necdet, "Imparatorluktan Cumhuriyete, Türk Mali Politikasına Bakış," Türk Tarih Kurumu Dergisi, Belleten, Aralık 1991, c.LV, Sayı:214, s.770.

Ergene, H. Halil, Neden Hedef Türkiye? Ankara, Kiyap Yayın Dağıtım, 1993. 
Eroğlu Hamza, Türk Inkılâp Tarihi, Yeniden Düzenlenmiş,Genişletilmiş, Yeni Baskı, Ankara, Savaş Yayınları, 1990.

Fromkin, David, Barışa Son Veren Barış, Modern Orta Doğu Nasıl Yaratıldı? 19141922, Çev. Mehmet Harmancı, İstanbul, Sabah Yayınları, 1994.

Gnkur. ATASE Bşk.lığı, Birinci Dünya Harbi'nde Türk Harbi, c.IV, Ks.2, SinaFilistin Cephesi, Ankara, Gnkur. Basımevi, 1986, s.83.

..., Türk İstiklal Harbi, c. IV, Güney Cephesi, Ankara, Gnkur. Basımevi, 1966.

Türk İstiklal Harbi, c.I, Mondros Mütarekesi ve Tatbikatı, 3.b., Ankara, Gnkur.Basımevi, 1999.

Birinci Dünya Harbi'nde Türk Harbi, c.III, Ks.2, 1914-1918, Irak-İran Cephesi, Ankara, Gnkur. Basımevi, 2002.

Göze, Ayferi, Türk Kurtuluş Savaşı ve Devrim Tarihi, 4. b., İstanbul, Beta Basım Yayım ve Dağıtım, 1993.

Gülmez, Nurettin, Kurtuluş Savaşı'nda Anadolu'da Yeni Gün, Ankara, Atatürk Kültür, Dil ve Tarih Yüksek Kurumu, Atatürk Araştırma Merkezi Yayını, 1999.

Hacettepe Üniversitesi, Atatürk ve Türkiye Cumhuriyeti, 5.b., Ankara, Siyasal Kitabevi, 2004.

Hammer, Joseph Von, Osmanlı Tarihi, c.1, Çev. Mehmet Ata, İstanbul, Milli Eğitim Basımevi, 1997.

Harp Akademileri Komutanlığı, Lozan Antlaşması, Montreux Sözleşmesi ve Paris Sözleşmesi, İstanbul, Harp Akademileri Basımevi, 1987.

İnalcık, Halil, Atatürk ve Demokratik Türkiye, İstanbul, Kırmızı Yayınları, 2007.

Kalafat, Yaşar, Şark Meselesi Işı̆ı̆ında Şeyh Sait Olayı, Karakteri, Dönemindeki İ̧̧ ve Dış Olaylar, Ankara, 1992.

Karal, Enver Ziya, Osmanlı Tarihi, c.V, Nizam-ı Cedit ve Tanzimat Devirleri, 17891856, 2.b., Ankara, Türk Tarih Kurumu (TTK) Yayınları, 1961,

Enver Ziya, Osmanlı Tarihi, c.IX, Ikinci Meşrutiyet ve Birinci Dünya Savaşı, 1908-1918, Ankara, Türk Tarih Kurumu (TTK) Yayınları, 1996.

Karlı, Ercan, Osmanlı Tarihi, İstanbul, Geçit Kitabevi Yayınları, 2003.

Kennedy, Paul, Büyük Güçlerin Yükseliş ve Çöküşleri, (1500'den 2000'e Ekonomik Değişme ve Askeri Çatışmalar), Çev. Birtane Karanakçı, 7.b., Ankara, Türkiye İs Bankası Kültür Yayınları,1998 
Kinross, Lord, Atatürk, Bir Milletin Yeniden Doğuşu, Çev. Necdet Sander, 14.b., İstanbul, Altın Kitaplar, 2003.

Kodaman, Bayram, Sultan II.Abdülhamid Devri Doğu Anadolu Politikası, Ankara, Türk Kültürü Araştırma Enstitüsü Yayınları, 1987.

Kürkçüoğlu, Ömer, Türk-İngiliz İliş̧kileri (1919-1926), Ankara Üniversitesi Siyasal Bilgiler fakültesi Yayınları, Ankara, 1978.

Lewis, Bernard, Orta Doğu, Hıristiyanlığın Doğuşundan Günümüze Orta Doğu'nun 2000 yıllık Tarihi, Çev. Mehmet Harmancı, 2.b., İstanbul, Sabah Yayınları, 1999.

Bernard, Modern Türkiye'nin Doğuşu , Çev. Metin Kıratlı, 9.b., Ankara, Türk Tarih Kurumu Yayınları, 2004.

Mumcu, Uğur, Kürt-İslâm Ayaklanması, 1919-1925, 17.b., Ankara, Tekin Yayınevi, 1995.

, Ugur, Kazım Karabekir Anlatıyor, 15.b., İstanbul, Tekin Yayınevi, 1995.

Öke, Mim Kemal, Musul Meselesi Kronolojisi, İstanbul, Türk Dünyası Araştırmaları Vakfı Yayınları, 1987.

, Mim Kemal, Ingiltere'nin Güneydoğu Anadolu Siyaseti ve Binbaşı E.W.C. Noel'in Faaliyetleri, (1919), Ankara,Türk Kültürünü Araştırma Enstitüsü Yayını,1988.

Mim Kemal, Belgelerle Türk-Ingiliz İlişkilerinde Musul ve Kürdistan Sorunu, 1918-1926, Ankara, Türk Kültürünü Araştırma Enstitüsü Yayınları, 1992.

, Mim Kemal, Musul-Kürdistan Sorunu, 1918-1926, İstanbul, İz Yayıncılık. 1995.

Önder, Ali Tayyar, Türkiye'nin Etnik Yapısı, 16.b., Ankara, Fark Yayınları, 2007.

Roux, Jean-Paul, Türklerin Tarihi, Büyük Okyanus'tan Akdeniz'e İki Bin Yıl, Çev. Galip Üstün, 6.b., İstanbul, Milliyet Yayınları, 1998.

Sahillioğlu, Halil, “Osmanlı Döneminde Irak'ın İdari Taksimatı” Çev. Mustafa Öztürk, Türk Tarih Kurumu (TTK) Dergisi, Belleten, (Aralık 1990), c.LIV, Sayı:211.

Saray, Mehmet, Ermenistan ve Türk-Ermeni İlişkileri, Genişletilmiş 2.b., Ankara, Atatürk Kültür, Dil ve Tarih Kurumu Atatürk Araştırma Merkezi Yayınları, 2005.

Selek, Sabahattin, Anadolu İhtilali, c.I, 4.b., İstanbul, Burçak Yayınevi, 1968.

, Sabahattin, İsmet İnönü, Hatıralar, c.II, Ankara, Bilgi Yayınevi, 1987. 
Soyak, Hasan Rıza, Atatürk'ten Hatıralar, c.I, İstanbul, Yapı ve Kredi Bankası Yayınları, 1973.

Şimşir, Bilal N. , Türk-Irak Illişkilerinde Türkmenler, Ankara, Bilgi Yayınevi, 2004.

, Bilal N., Atatürk ve Cumhuriyet, İstanbul, İleri Yayıncılık, 2006.

Taneri, Aydın, Türkistanlı Bir Türk Boyu Kürtler: Kürtler'in Kökeni, Siyasi, Sosyal ve Kültürel Hayatları, Ankara,1983.

Tansel, Selahattin, Mondros'tan Mudanya'ya Kadar, c.I., İstanbul, Milli Eğitim Bakanlığı Yayınları, 1991.

Tezer, Şükrü, Atatürk'ün Hatıra Defteri, 3.b., Ankara, TTK Yayınları, 1995.

Tunçoku, A.Mete, Türk Tarihi İçinde Atatürk ve Cumhuriyet, Ankara, Gnkur. ATASE Bşk.lı̆gı Yayınları, 2001.

Turan, Refik, Atatürk İlkeleri ve Inkılâp Tarihi, Ankara, Siyasal Kitabevi, 1999.

Üçok, Coşkun, Siyasal Tarih, 1789-1950, s.b., Ankara, Türk Matbaası Yayınları, 1961.

Volkan, Vamik D. ve Itzkowıtz Norman, Ölümsüz Atatürk, Ankara, Baglam Yayınları, 1998.

Winstone, H.V.F., Ortadoğu Serüveni, 1898-1926 Yllları Arasında Ortadoğu'daki Siyasi ve Askeri İstihbaratın Öyküsü, Çev. Fuad Davudoğlu, İstanbul, Risale Yayınları, 1999.

Yergin, Daniel Petrol, Para ve Güç Çatısmasının Epik Öyküsü, Çev. Kamuran Tuncay, 2.b., Ankara, Türkiye İş Bankası Kültür Yayınları, 1999.

Yüksek Ögretim Kurulu (YÖK), Atatürk Illkerleri ve Inkılap Tarihi, c. I/I, Türk İnkılabının Hazırlık Dönemi ve Türk İstikbal Savaşı, 3.b., Ankara, Yüksek Ögretim Kurulu (YÖK) Yayınları, 1994. 